\title{
Low-cost Adsorbents Derived from Agricultural By-products/Wastes for Enhancing Contaminant Uptakes from Wastewater: A Review
}

\author{
Mohamed Sulyman ${ }^{1 *}$, Jacek Namiesnik ${ }^{1}$, Andrzej Gierak ${ }^{2}$ \\ ${ }^{1}$ Chemical Faculty, Gdansk University of Technology, Poland \\ ${ }^{2}$ Department of Physical Chemistry, Jan Kochanowski University, Poland
}

Received: 23 August 2016

Accepted: 6 November 2016

\begin{abstract}
A major threat to the comfort of human life has been imposed by increased industrialization and urbanization. The generation and disposal of huge amounts of toxic materials and pollutants have heavily contaminated our environment. Some Organics such as synthetic dyes (SD) and heavy metals (HM) are becoming increasingly prevalent as the most dangerous pollutants in soil and surface water environments. They are causing great concern worldwide due to their toxicity to many life forms.

Environmentally friendly utilization of agricultural by-products/waste materials either as raw materials or in production of so-called activated carbons (AC) is an important issue. Because it is apparent from our literature review that the main factors characterizing these materials are their affordability, local availability, and efficiencies in removing many unwanted toxics and pollutants, they therefore could be utilized instead of more conventional but expensive adsorbent materials, particularly in developing countries where many industries lack appropriate individual sewage treatment systems; even where they exist, they lack satisfactory functioning and maintenance because of the lack of good budgets.

A number of case studies are supplied in this review. These case studies have pointed to the efficient removal of SD/HM ions from aqueous solutions by the agricultural by-products/wastes in the form of a raw material, signifying spent tea leaves (STL) as a good example. Besides, the efficient removal of such ions by AC produced from these agricultural by-products/wastes has also been given in detail, suggesting a variety of AC agricultural by-products/wastes sources. Both kinds are widely used adsorbents in the treatment of wastewaters. Our review has shown that these adsorbents are characterized by many exceptional physical and chemical features that make them widely used adsorbents in the treatment of wastewaters. The adsorption efficiencies by these substances were also affected by the characteristics of AC, which depend on the physical and chemical properties of the precursor (i.e., agricultural by-products/wastes) as well as on the activation method applied, which is either chemical or physical. The structural properties of the resulting
\end{abstract}

*e-mail: mohsulym76@yahoo.com 
$\mathrm{AC}$ can be affected by a number of factors such as time of activation, temperature of activation, and the oxidizing agent used in addition to the starting precursor.

Keywords: activated carbon, agricultural by-products/waste, adsorption, heavy metals, synthetic dyes

\section{Introduction}

In the past few decades, urban and industrial activities have contributed enormously to the pollution of the environment, which has become a major problems that needs to be solves or at least controlled. The excessive release of colored effluent and the dyestuff wastewaters produced by the textile, paper board, wood pulp, paper, fertilizer, paint, and pigment industries comprises one source. The released dye in water streams represents a risk of ecotoxicity and a potential danger of bioaccumulation. The transport of these contaminants through the food chain could even affect human health [1].

Synthetic dyes (SD) and heavy metals (HM) are usually found as part of their constituents and can be two examples posing a global problem. This fact implies the need to conduct treatment processes to the SD and HM containing water before discharging to the environment. According to the United Nations World Water Development Report, 2 million tons of waste are discharged to water bodies daily, including industrial wastes, dyes and chemicals, and human and agricultural wastes (fertilizers or pesticides) [2], about 10,000 various commercial dyes and pigments exist and over 700,000 tons are produced annually worldwide [3]. More than 600 organic and inorganic pollutants have been reported in water along with microbial populations. Among these pollutants, heavy metal ions are very dangerous due to their toxic and carcinogenic nature. Moreover, some metal

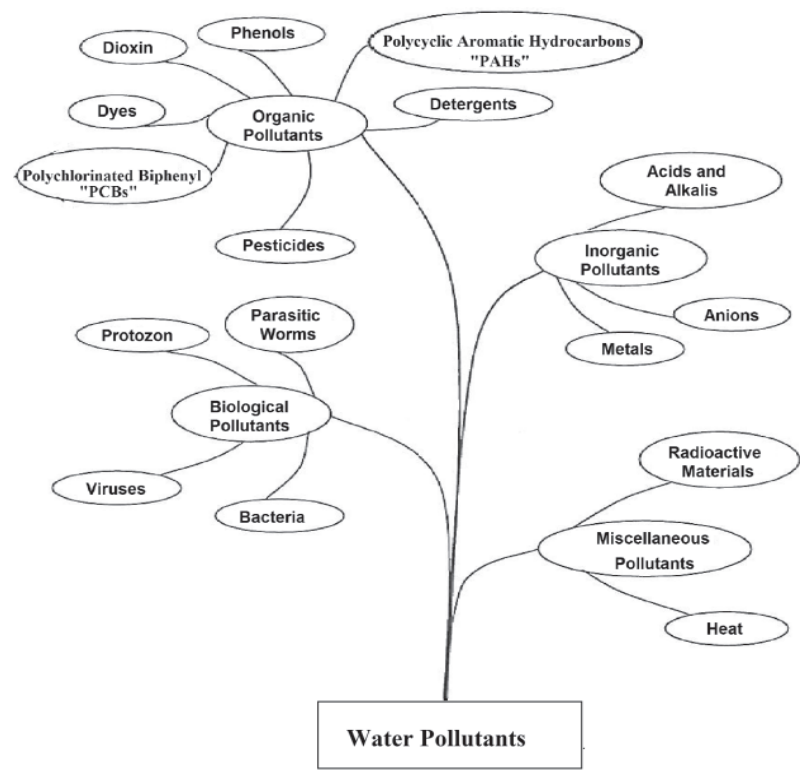

Fig. 1. Classification of water pollutants on the basis of their chemical nature [2]. ions are not biodegradable or bio-transformable and, hence, exist in the environment for a long time. In general, water pollutants have been categorized into four groups: organic, inorganic, miscellaneous, and biological. Water pollution accounts for the deaths of more than 14,000 people daily [2]. Fig. 1 shows a classification of water pollutants.

According to the U.S. EPA (2007), the top toxins release inventory emitters to surface water by industry are shown in Figure 2 [4-5]. From an environmental point of view, the environmental benefits of reducing U.S. office paper use by 540,000 tons can protect about 11 billion gallons of wastewater - enough to fill 16,000 OlympicSized swimming pools. While 1.9 million tons of wood use, whose annual equivalent is 13 million typical trees [5-6].

In the last few years, many different conventional technologies have been applied to the removal of heavy metals and dyes from wastewater. These techniques include chemical precipitation, membrane filtration, ionexchange, electrolysis, coagulation, solvent extraction, reverse osmosis, and electrocoagulation [7]. However, most of these mentioned techniques have their own advantages and limitations in application [8]. Most of them suffer from some defects such as incomplete removal of contaminants and are characterized by low selectivity, applications of high reagent, chemical and energy requirements, the generation of other toxic wastes that need to be handled carefully, and - even more important high cost [9]. Conversely, biosorption was defined as the

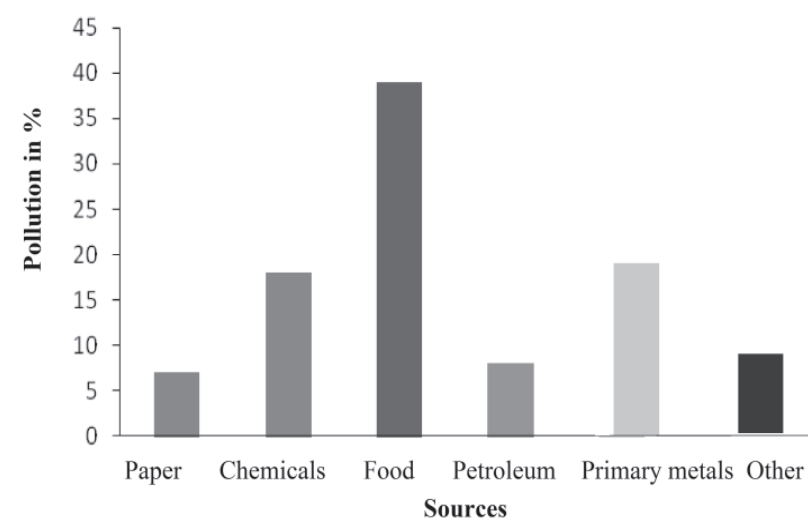

removal of materials such as HM ions and SD molecules by inactive, non-living material or biological origin and has arisen as an effective alternative, a fine eco-friendly technology, and at low cost [10].

Fig. 2. Top toxins release inventory emitters to surface water by industry, 2005 [6]. 
Among all these mentioned techniques involving reclamation of industrial and municipal wastewater, adsorption is generally found to be a very promising one due to its high effectiveness and complete removal of metal ions even at low concentrations, and its low cost and easy adaptation and sorbent material separation from the aqueous phase after finishing treatment [11].

From an economical point of view, an economic sorbent is known as a sorbent that is abundant in nature and can be easily available, or is a by-product or waste from industry, has little or no economic value, and requires little or no processing. Agricultural residues, also called ligno cellulosic biomass resource, are defined as a biomass byproduct from the agricultural system and include stalks, leaves, seeds, shell, peels, husks, and straws. These wastes can be classified into two groups. One belonging to those residues remaining in the field after harvest or autumn season where leaves wither and fall, for example tree fronds [12] and oak tree (L.) dead leaves [13]. The other group can belong to by-products of industrial processing, for example date stones [14-15], olive stones [16], and tea leaves [17-18].

Carbonization of biomass has a number of advantages when compared with common biological treatments. It generally takes only hours (instead of the days or months required for biological processes), permitting a more compact reactor design. The high process temperatures can destroy pathogens and such potential organic contaminants as pharmaceutically active compounds that could be present, for example, in AR [19]. On the other hand, the preparation of activated carbon is usually conducted at relatively high temperatures in a conventional convective or conductive heating system. The thermal process may take a long processing time to reach the desired level of activation, which is also a considerable risk of overheating, leading to complete combustion of the carbon [20].

In the present article, the suitability of lingo-cellulosic bio-sorbents and AC derived from agricultural byproducts/ wastes and their diverse availability as to provide alternative adsorbents for wastewater treatment has been reviewed. Besides, the purpose of this article is to review the available information on the various attributes of utilization of either the raw agricultural by-product/wastes or AC in treatment wastewaters. A number of case studies concerning the application of agricultural by-products/ wastes as raw material and $\mathrm{AC}$ by a variety of researchers in providing effective adsorbents have also been covered as part of this review to make the reader aware of the importance of such materials. The main advantages of this review are:

1) Extensive review for the recycling of agricultural by-product/wastes as feedstock for the production of green and potentially low-cost adsorbents in one case as raw material and in the other as an activated carbon for use in wastewater treatment.

2) Showing a wide range of agricultural by-product/ wastes could be used as renewable sources for the production of AC.
3) Another main advantage is that this review showed extensive studies with the aims of finding an alternative in the form of economic adsorbents for wastewater treatment.

4) A comparison between results done by several studies for enhancing contaminant uptakes by raw and activated carbon of agricultural by-product/wastes.

5) A new proposal design of packed bed column filled with potential adsorbent for the adsorption of HMs and SD from waste liquid at laboratories of universities, colleges, and research centers.

6) Showing that agricultural waste materials are an environmental issue of economic value, and the best way could be to solve the disposal and pollution problem of these wastes, which is recycling technology.

\section{Adsorbent Resources}

Recently, special attention has been paid for the utilization of the available-in-nature, abundant, and eco-friendly sorbents to replace the conventional and expensive sorbents based on economic and environmental point of views [21]. In name they are called ACs. These substances are mostly synthesized and developed by the pyrolysis of carbonaceous materials of plants and agricultural residues/wastes such as coconut shells [22], walnut shells [23], palm shells [24], date stones [14, 25], almond shells [26], spent tea leaves (STL) [1718], and cotton stalks [27], followed by either physical or chemical activation of the chars obtained from them [12]. Other more economical materials have been studied for the adsorption of SD from synthetic wastewaters, replacing the AC. For example, they are represented by clay materials (bentonite, kaolinite), siliceous materials (zeolites, alunite, perlite), and industrial waste products (i.e., waste carbon slurries, metal hydroxide sludge, coffee wastes) [28-32]. The unavailability of such materials with the desired specifications can be an obstacle detaining its utilization.

On the other hand, plant and tree leaves, most available and abundant particularly in public gardens and woods, have been proposed and reported as being economical, suitable, and simple agro-adsorbents for the study of SD and toxic HM removal [17, 33-37]. Carbonization of these high-in-carbon content plant and tree leaves can also be used in production of AC [16, 38-39].

Expanding fruit production has naturally resulted in increased amounts of waste every year [40]. It was reported that in the world several million tons of agricultural wastes are being disposed of every year. In India alone more than 400 million tons of agricultural residue is generated annually [41], and it is estimated that the production of coir pith in India is 0.5 million tons, and coir pith is disposed of as a waste and its accumulation around coir-processing centers is creating a menace [42]. And about 3.5 million tons of tea are consumed worldwide [17].

The global production of dates was 7,429,811 tons in 2009 [40, 43], while 198,000 tons of date leaf are produced 
each year in Tunisia [40, 44]. The main components of date palm leaves are cellulose $38.10 \%$, hemicellulose 22.74\%, lignin 11.95\%, and ash 7.71\% [45]. According to the United Nations Food and Agriculture Organization (FAO), tomato is the most widely grown product in fresh vegetables around the world with a production of 145.6 million tons, and a new nonporous carbon from tomato waste as a low-cost adsorbent has been prepared by Fuat et al. (2014) [46].

While 68 million tons of orange are produced globally according to FAO, the generation of orange waste is estimated to be in the range of 15 to 25 million tons - a big volume if these wastes are still dumped every year, which causes both economic and environmental problems such as high transportation cost, lack of dumping site, and accumulation of high organic content material [47]. Rice husk is the major by-product of the rice milling industry, accounting for almost $20 \%$ of rice production [48-49]. As rice plant is the main cereal crop in Malaysia with an annual output of more than 180 million tons, the production of rice husk is over 36 million tons [49]. Generally, farmers and rice processors often burn rice husk as wastes, and this is what releases carbon dioxide $\left(\mathrm{CO}_{2}\right)$ into the atmosphere [50]. Rice husks have been reported as a good sorbent of many metals and basic dyes [51], and the main components of the rice husk are cellulose $32.24 \%$, hemicellulose $21.43 \%$, lignin $21.44 \%$, and ash content $15.05 \%$ [51].

Coffee fruit processing is one of the most polluting activities in agriculture due to the large amount of waste generated in the process. According to the International Coffee Organization, the production of coffee amounted to about 680 million tons in 2008 [52]. Part of the waste is used as fertilizer, but most of the coffee grounds are dumped or burned. Globally, coffee and tea as a beverage are the second most consumed by all citizens after water. In the last few years, the consumption of coffee has rapidly increased, especially by young people. According to a survey done by Sulyman (2016) [5], which included 25 cafes in the city of Tripoli, Libya, the average generation of coffee ground wastes by only the 25 cafes is estimated to be in the range of (36-45) tons annually, and a big volume of this waste is still kept in big plastic bags for disposal by conventional methods, which are burned or dumped. It is also estimated that in one of these cafes, more than 100 cups of coffee are drunk within an hour, while in the city of Gdansk, Poland, at one café that was surveyed, more than 1,600 cups of coffee are consumed daily. And the average of coffee ground wastes at the 25 cafés is estimated to be in the range of 72-90 tons annually. However, coffee grounds are carbonaceous and have the potential to be converted into an adsorbent. This conversion could contribute to reducing the volume of waste, while producing an adsorbent with a lower cost. Moreover, conversion may prevent the discharge of carbon dioxide - one of the causes of global warming [53]. It has been reported that the amount of carbon dioxide produced by the combustion of 1,000 $\mathrm{g}$ of coffee grounds is estimated to be $538 \mathrm{~g}$ [54].
On the other hand, the total primary production of sea plant p. oceanicu (L) in the Mediterranean basin alone has been estimated in the range of 5-50 million tons per year [55]. In the United States, about 30 million tons of oak leaves are collected and burned every year. A new activated carbon from oak 1 . dead leaves as low-cost adsorbent has been produced [13]. In India, national walnut production oscillates between 40,000 to 45,000 tons per year, and the process involved to obtain unshelled walnuts generates more than 25,000 tons of shell, and approximately 11,000 tons of almond shell waste every year [56].

Olive oil is nearly totally produced in the Mediterranean region. As the demand for olive oil is rapidly increasing worldwide, environmental pollution posed by olive mill wastes (OMW) such as olive cake is a growing problem. According to the International Olive Council (IOC, 2012), the provisional figures of worldwide olive oil production for 2010-11 is 3.019 million tons of olive oil - an increase of 45,000 tons (or $1.5 \%$ ) over the previous season [57]. Olive mills generate a huge amount of waste accumulate around the olive mill, and it was reported that the $1,000 \mathrm{~kg}$ of olive fruit can produce about $350 \mathrm{~kg}$ of olive cake. Most of the farmers were not able to specify the quantities of olive cake generated from the extraction process, as olive cake is not stored but dumped near the olive mill facility; $93.1 \%$ of the olive husk produced is granted to farmers, who use it for heating after drying, as well as for animal feed. The remaining quantities are then dumped in open lands [57], the exhausted olive cake has a high lignin, cellulose, hemicellulose, and low content of ash, which were found to be $14.18 \%, 24.14 \%, 11.0 \%$, and $2.36 \%$, respectively [58].

\section{Recycling of Agricultural By-Products/Wastes}

So far in many countries all over the world, where the bulk of fruit and other food material is produced and consumed, a major proportion of their wastes are still carried to open areas for disposal by burning or dumping, and this releases a lot of toxic material and pollutants, as well as carbon dioxide $\left(\mathrm{CO}_{2}\right)$, to the environment. However, recycling such wastes as raw materials for producing activated carbon could be the better option for minimizing disposal landfills and pollution problems of agricultural by-product/wastes, and economically at the same time [5].

Sorbents such as AC can be manufactured from both agricultural by-products and wastes [16], in addition to industrial by-products and wastes [14], while sorbents in the form of unprocessed or semi-processed agricultural by-products/wastes such as dry plant leaves can be found in abundance in public gardens, national forests [13], and private farms [59] as a result of natural annual falling withered leaves in the autumn; they are also called forestry wastes. Waste or spent tea leaves are also known as lowcost biologically originated and have been recommended as novel adsorbents for the removal of toxic HMs such 


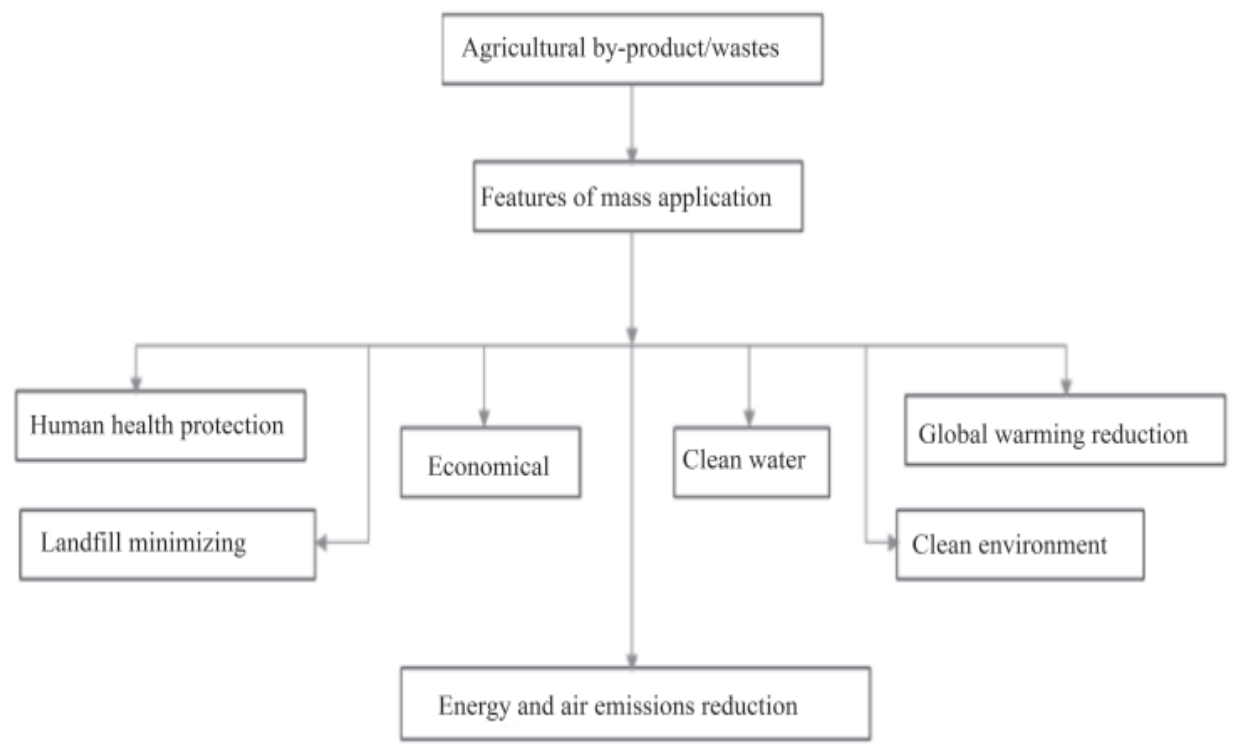

Fig. 3. Scheme representation of features of mass application derived from agricultural by-products/wastes [5].

as $\mathrm{Pb}(\mathrm{II})$ [60], $\mathrm{Cu}(\mathrm{II})$ [61], and some organic pollutants (e.g., pesticides, SD, etc.) [18, 62-66]. Fig. 3 shows the main advantage and predictable features of the mass application derived from agricultural by-products/wastes [5]. On the other hand, Figure 4 shows the possibility of recycling agricultural by-products/wastes as the main precursor to synthesize either AC through carbonization (track 1 in Fig. 4) or can be used as raw materials that need little or infrequently no processing (track 2 in Fig. 4). They afterwards can be used as adsorbents for different applications.

\section{Applications of Agricultural By-products/wastes as Sorbents}

\section{Raw Agricultural By-products/Wastes as Sorbents}

The by-products/wastes from some agricultural substances may be used as an alternative food resource for ruminant animals. There are many companies using a certain whole plant or parts of the plant for the production of a good quality usable product. However, they produce

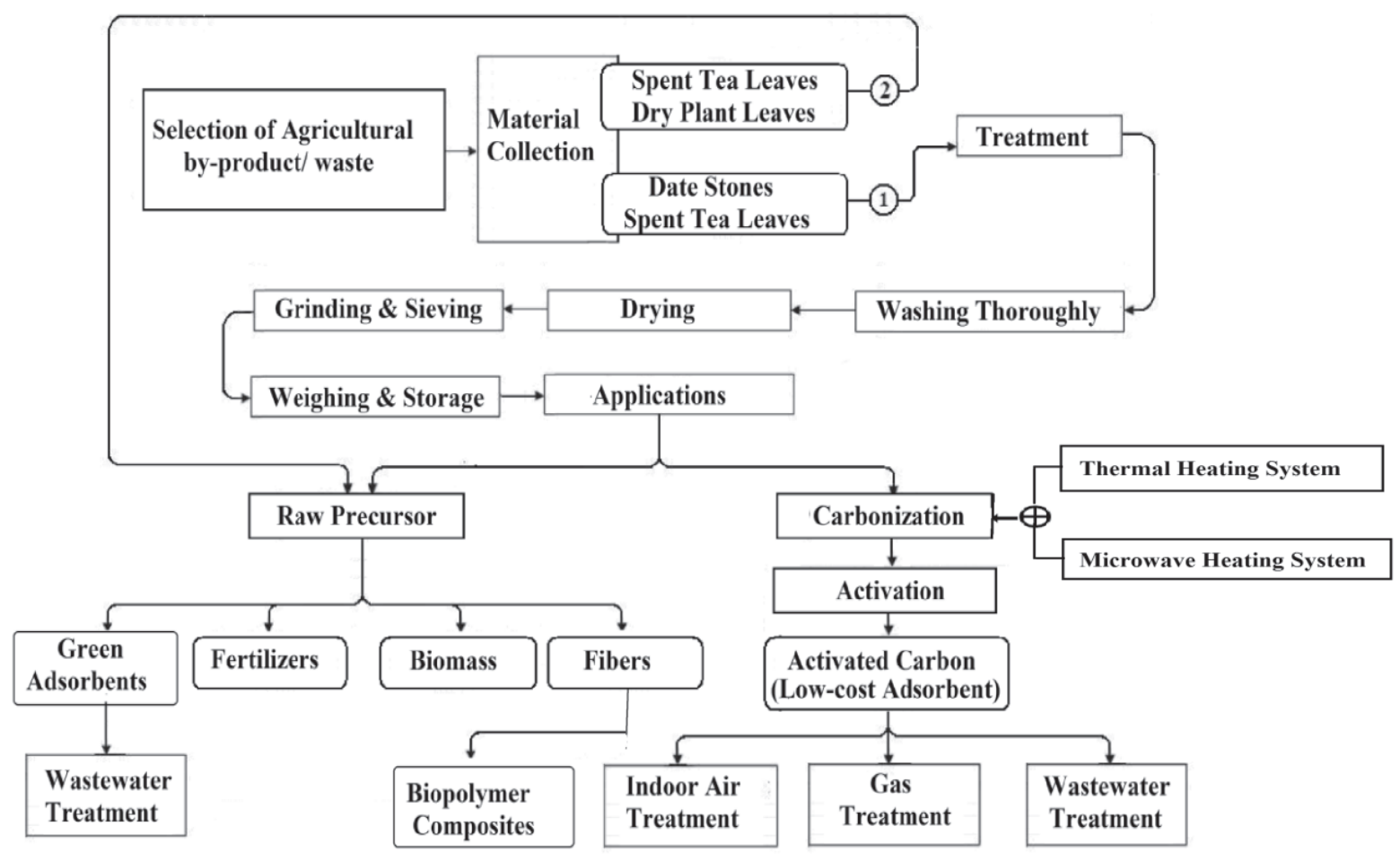

Fig. 4. Scheme of agricultural by-products/wastes recycling. 
Table 1. Compilation results on the adsorption of various pollutants' raw agricultural by-product waste.

\begin{tabular}{|c|c|c|c|}
\hline Sorbents & $\begin{array}{l}\text { Pollutant } \\
\text { sorbed }\end{array}$ & $\mathrm{q}_{\max ,} \mathrm{mg} / \mathrm{g}$ & Ref. \\
\hline Potato peels & $\mathrm{Ni}(\mathrm{II})$ & 13.09 & [74] \\
\hline Peanut shell & $\mathrm{Cu}(\mathrm{II})$ & 25.30 & [75] \\
\hline Peanut shell & $\mathrm{Cr}(\mathrm{III})$ & 27.86 & [75] \\
\hline Mango leaves & $\mathrm{Cu}(\mathrm{II})$ & 15.77 & [76] \\
\hline Cello lignin wastes & $\begin{array}{l}\text { Methylene } \\
\text { Blue }\end{array}$ & 95.2 & [77] \\
\hline Modified peanut shell & $\operatorname{Hg}(\mathrm{II})$ & 30.72 & [78] \\
\hline Modified peanut shell & $\mathrm{Cd}(\mathrm{II})$ & 14.17 & [78] \\
\hline Sunflower leaves & $\mathrm{Cu}(\mathrm{II})$ & 89.37 & [79] \\
\hline Spent tea leaves & $\mathrm{Zn}(\mathrm{II})$ & 79.76 & [80] \\
\hline Spent tea leaves & $\begin{array}{l}\text { Methylene } \\
\text { Blue }\end{array}$ & 62.2 & [39] \\
\hline Raw coffee residue & Remazol Blue & 232 & [32] \\
\hline Seaweed & $\mathrm{Pb}(\mathrm{II})$ & 893 & [81] \\
\hline Oak sawdust & $\begin{array}{l}\text { Methylene } \\
\text { Blue }\end{array}$ & 29.94 & [82] \\
\hline $\begin{array}{l}\text { Mangrove plant leaf } \\
\text { powder }\end{array}$ & Crystal Violet & 200 & [83] \\
\hline $\begin{array}{l}\text { Mangrove plant fruit } \\
\text { powder }\end{array}$ & Crystal Violet & 250 & [83] \\
\hline Mango leaf powder & Crystal Violet & 200 & [83] \\
\hline Pine cone & Acid Blue 7 & 37.4 & [84] \\
\hline Walnut sawdust & $\begin{array}{l}\text { Methylene } \\
\text { Blue }\end{array}$ & 59.17 & [82] \\
\hline Rice husk & $\begin{array}{l}\text { Methylene } \\
\text { Blue }\end{array}$ & 40.6 & [85] \\
\hline Rice husk & $\begin{array}{l}\text { Indigo } \\
\text { Carmine }\end{array}$ & 65.9 & [86] \\
\hline Spent tea leaves & $\mathrm{Pb}(\mathrm{II})$ & 120.8 & [80] \\
\hline Spent tea leaves & $\mathrm{Cu}(\mathrm{II})$ & 90 & [62] \\
\hline Orange peel & $\mathrm{Pb}(\mathrm{II})$ & 204.50 & [87] \\
\hline Spent tea leaves & $\mathrm{Cr}(\mathrm{II})$ & 47.98 & [88] \\
\hline Almond peel & $\begin{array}{l}\text { Methylene } \\
\text { Blue }\end{array}$ & $77-118$ & [89] \\
\hline Spent tea leaves & $\mathrm{Ni}(\mathrm{II})$ & 18.42 & [90] \\
\hline Coconut bunch waste & $\begin{array}{l}\text { Methylene } \\
\text { Blue }\end{array}$ & 70.92 & [91] \\
\hline Spent tea leaves & $\begin{array}{l}\text { Methylene } \\
\text { Blue }\end{array}$ & 300.052 & [65] \\
\hline Spent tea leaves & $\begin{array}{c}\text { Basic Violet } \\
10\end{array}$ & 71.4 & [92] \\
\hline Spent tea leaves & $\begin{array}{l}\text { Malachite } \\
\text { Green }\end{array}$ & 227.3 & [93] \\
\hline Wood apple shell & $\begin{array}{l}\text { Methylene } \\
\text { Blue }\end{array}$ & 95.2 & [94] \\
\hline
\end{tabular}

Table 1. Continued

\begin{tabular}{|c|c|c|c|}
\hline Wood apple shell & Crystal Violet & 130 & {$[94]$} \\
\hline Broad bean peels & $\begin{array}{c}\text { Methylene } \\
\text { Blue }\end{array}$ & 192.7 & {$[95]$} \\
\hline Melon peel & $\begin{array}{c}\text { Methylene } \\
\text { Blue }\end{array}$ & 333.33 & {$[96]$} \\
\hline Olive stones & Cd (II) & 0.575 & {$[97]$} \\
\hline Olive stones & Phenol & 333.3 & {$[57]$} \\
\hline
\end{tabular}

large quantities of chaff that are eventually burnt. Apart from losing the economic value of the waste, a huge amount of capital is expended in disposing of it. In some countries, waste constitutes environmental hazards through inconvenient damping or incineration. Leaves represent a part of the plant, and a good example of these agro-sorbents that need little (track 1 in Fig. 4) or no processing (track 2 in Fig. 4). They are attracting attention as simple and cheap methods for the removal of several metal ions [59, 67-68] and organic pollutants [12, 69]. Examples of these sorbents are Posidonia oceanic $L$. dead leaves [33], pine tree leaves [34], Acacia nilotica L. leaves [35], and tea leaves [17].

Some scientific reports show that a number of plant leaves (carob, cinchona, cypress, figs, guava, loquat, olive, oak, pine, pistachio, poplar, reed, sissy, walnut, and willow) can be used to remove zinc ( $\mathrm{Zn}$ ) from aqueous solution, and the maximum efficiency of Zn removal was found by walnut and poplar leaves at $\mathrm{pH} 6$ with 82\% [59]. Leaves of poplar were found to be effective in removing lead $(\mathrm{Pb})$ [70], and copper $(\mathrm{Cu})$ [71]. While removing cadmium $(\mathrm{Cd})$ from aqueous solutions was found best with the use of reed leaves [72]. When a number of dry plant leaf residues (mulch) were used as adsorbents for the removal of $\mathrm{Pb}, \mathrm{Cd}$, and $\mathrm{Cu}$ from aqueous solutions, the efficiencies of these removals by these different dry plant leaves, at optimal conditions, were close to the efficiency of removal done by AC. However, the efficiencies of these dry leaves for the removal of the studied metals varied from one to another. The removal of metals was at maximum $\mathrm{pH}$ of 7.0 for $\mathrm{Cd}$ and 5.4 for $\mathrm{Cu}$. The type of plant leaves processing also had an effect on the efficiency of metal removal, in that oven-dried leaves showed slightly higher removal efficiency of metal ions than the naturally dried leaves, based on a research study conducted by Salim and Abu El-Halawa (2002) [68].

In addition to the type of plant leaves and their processing method as factors effecting the removal of the polluting adsorbates (e.g., HM/SD), there are also several other factors such as $\mathrm{pH}$, concentration of leaves, concentration of adsorbates, and the presence of competing ions that may affect the efficiency of removal. The effect of solution $\mathrm{pH}$ was evident at neutral $\mathrm{pH}$ for the most efficient adsorption of nickel (Ni) from polluted water using pine leaves [73], while the increase 
in agitation time and the initial concentration of crystal violet $(\mathrm{CV})$ and rhodamine (RHB) efficiently caused an increase in adsorption onto Acacia nilotica leaves [35]. An increase in temperature of adsorption reaction was very effective in the removal of $\mathrm{CV}$ from aqueous solution at only 60 min by STL [64]. Recently, several workers have reported that the agricultural by-products/wastes have the potential to be applied as alternative low-cost sorbents in the remediation of heavy metal contamination and dyes in wastewater. Table 1 shows applications of agricultural by-product wastes as adsorbents for wastewater treatment.

\section{Internal Structure of an Adsorbent Derived from Raw Agricultural By-products/Wastes}

It is well known that raw agricultural by-products/ wastes usually contain polysaccharides of hemicellulose, cellulose, and lignin within their cellular constituents as major structural components. For this reason, they are called lignocellulosic substances. The structures of these biochemical substances in some parts are associated with a number of functional groups such as hydroxyl, methyl, and carbonyl groups. When such materials are ready as sorbents for their intended task (i.e., wastewater treatment), these functional groups become responsible for $\mathrm{HM}$ ion and SD molecules sorption [98-99]. For instance, plant leaves (i.e., STL) are agricultural residues and can be classified as one type of bio sorbent because they present lignocellulosic materials [98, 100-101]. The abundance of natural occurrences and the presence of large amounts of surface functional groups make various agriculture wastes good alternatives to those expensive commercial ACs [102]. It was shown that lignocellulosic substances have ion-exchange capacity and general sorptive characteristics, which both are derived from their biochemical constituent structure and polymers [103]. The polymers include extractives that are of small molecular size and available in little quantity, pectin, and protein in addition to the aforementioned components: cellulose, hemicelluloses, and lignin [98, 103].

STL represent one good example of an agricultural byproduct/waste found in abundance, a low-cost adsorbent, utilized extensively in wastewater treatment, and that requires little or sometimes no processing. From this point forward in this article, STL has been chosen as a case study used and investigated as a novel sorbent for effective HM ions and SD removal from aqueous solutions/wastewaters.

\section{Case Studies on Raw Agricultural By-product/Wastes}

\section{Spent Tea Leaves as Effective Sorbents}

More than 3 million tons of tea leaves are produced worldwide annually [63] and it is consumed by a huge number of people, and only water is consumed by more people. It is estimated that somewhere between 18 and 20 billion cups of tea are drunk daily [5, 104]. After hot water is extracted from the leaves, the residual mass is of
Table 2. Some physical properties and chemical compositions of STL.

\begin{tabular}{|c|c|c|}
\hline Physical properties (unit) & Value & Ref. \\
\hline Moisture content (\%) & 12.3 & \multirow{5}{*}{$\begin{array}{c}{[61],} \\
{[64]}\end{array}$} \\
\hline Pore volume (ml/g) & 2.9 & \\
\hline Percent porosity $(\%)$ & 75.0 & \\
\hline Specific gravity (g/ml) & 0.28 & \\
\hline Specific surface area $\left(\mathrm{m}^{2} / \mathrm{g}\right)$ & 175.5 & \\
\hline Chemical compositions (\%) & \multirow[b]{2}{*}{46.8} & \multirow{7}{*}{$\begin{array}{l}{[106],} \\
{[107]}\end{array}$} \\
\hline Cell wall material & & \\
\hline $\begin{array}{l}\text { Hot water-soluble polysaccharide- } \\
\text { proteins }\end{array}$ & 9.6 & \\
\hline Cellulose & 37.2 & \\
\hline Lignin \& structure proteins & 14.7 & \\
\hline Hot water insoluble protein & 12.1 & \\
\hline Polyphenols & 25.0 & \\
\hline Carbon (C) & 44.4 & \multirow{4}{*}{$\begin{array}{c}{[61],} \\
{[64]}\end{array}$} \\
\hline Hydrogen $(\mathrm{H})$ & 6.4 & \\
\hline Nitrogen $(\mathrm{N})$ & 3.4 & \\
\hline Oxygen (O) & 27.2 & \\
\hline
\end{tabular}

no use and hence is disposed of [61]. Black tea, made from the mild oxidation of tea leaves, amounts to around $78 \%$ of the entire production, followed by green tea at $22 \%$. Both of them, however, are obtained from basic tea leaves (Camllia sinensis L.) [105]. Some chemical and physical properties of spent tea leaves (STL) are shown in Table 2.

Sorption of toxic metals and organics on STL has been studied extensively in recent years due to their aforementioned advantageous properties. Among many studies published in scientific journals, the followings represent some examples of metal ions and SD removal.

Orhan and Buekguengoer (1992) [108] have investigated the removal of some metal ions such as $\mathrm{Al}$ ions from wastewater using STL, Turkish coffee, spent coffee, and nut and walnut shells as adsorbents in a batch mode experiment. Their results showed good adsorption potential for Al ions with removal efficiencies of $98 \%$, $99 \%, 96 \%$, and $96 \%$, respectively.

A similar adsorbent was the aim of another research study achieved by Hadi (2012) [109] when he investigated the possibility of using STL in comparison with commercial $\mathrm{AC}$ for removing toxic hexavalent chromium ions $\mathrm{Cr}(\mathrm{VI})$ from synthetic wastewater using a batch mode experiment. The equilibrium experiments were carried out for $180 \mathrm{~min}$. with the STL adsorbent dose range between 0.05 and 0.9 $\mathrm{g}$, and $100 \mathrm{ml}$ of $\mathrm{Cr}(\mathrm{VI})$ solution of initial concentrations ranged between 25 and $300 \mathrm{mg} / \mathrm{l}$. In conclusion, the maximum adsorption capacities of $\mathrm{Cr}(\mathrm{VI})$ were $42.46 \mathrm{mg} / \mathrm{g}$ and $42.42 \mathrm{mg} / \mathrm{g}$ using STL and AC, respectively. Another extensive study carried out by Rafie (2012) [17] focused 
on the use of a black STL for the removal of some HMs $(\mathrm{Co}, \mathrm{Cd}$, and $\mathrm{Zn})$ from wastewater. The batch adsorption experiment was observed for the three HMs at $180 \mathrm{~min}$. The results of the experiment showed that the rate of adsorption was affected by the process conditions such as initial metal concentration, adsorbent dose, solution $\mathrm{pH}$, and contact time. The quantities adsorbed per half gram of STL at equilibrium (qe) were $15.39 \mathrm{mg} / \mathrm{g}, 13.77 \mathrm{mg} / \mathrm{g}$, and $12.24 \mathrm{mg} / \mathrm{g}$ for $\mathrm{Co}, \mathrm{Cd}$, and $\mathrm{Zn}$, respectively.

A kinetic investigation was carried out by Hossain et al. (2005) [110] to evaluate the applicability of black STL as an adsorbent for the removal of $\mathrm{Cr}(\mathrm{VI})$ from aqueous solution in a batch mode experiment. They found that the adsorption of $\mathrm{Cr}(\mathrm{VI})$ occurred rapidly in the first $24 \mathrm{hr}$; then was followed by a slow process that required more than 10 days to reach its equilibrium. According to the experimental data, they also found that the initial $\mathrm{Cr}(\mathrm{VI})$ concentrations, $\mathrm{pH}$, and temperature were very effective parameters on the rate of adsorption. An alkali-treated STL (AT-STL) was used as a novel adsorbent to remove $\mathrm{Pb}$ ions from aqueous solution. The investigation was reported by Yang and Cui (2013) [60], whose comparative study of $\mathrm{Pb}$ ion removal from aqueous solution onto ATSTL, green tea leaves (GTL), and green spent tea leaves (GSTL) was conducted. The study was carried out at room temperature by adding $0.1 \mathrm{~g}$ of the aforementioned three adsorbents into a number of $250 \mathrm{ml}$ glass-stoppered conical flasks containing $100 \mathrm{ml}$ of $50 \mathrm{mg} / \mathrm{l} \mathrm{Pb}$ solution. The comparative study showed that AT-STL displayed a significantly higher removal rate of $\mathrm{Pb}$ ions than GTL and GSTL. According to the data obtained from the Langmuir model, the optimum adsorption capacity $\left(\mathrm{q}_{\mathrm{o}}\right)$ for $\mathrm{Pb}$ was obtained with a value of $64.10 \mathrm{mg} / \mathrm{g}$.

Tan (1985) [107] investigated the adsorption of $\mathrm{Cu}$ (II) by waste tea leaves and coffee powder using batch adsorption experiments. The results of the experiment showed that the tea leaves and coffee wastes are able to remove metal ions such as $\mathrm{Cu}$ (II) from solution. The extent of removal is a function of $\mathrm{pH}$, ionic strength, metal ion concentration, the nature of waste substrate used, and the presence of other competing ions or molecules.

Zuorro and Lavecchia (2010) [111] have investigated the removal of $\mathrm{Pb}$ (II) from aqueous solution using green and black STLs in a batch mode technique. Batch adsorption experiments were made at 25 and $40^{\circ} \mathrm{C}$ at initial lead-ion concentrations between 0.01 and $2 \mathrm{~g} / \mathrm{l}$ at $25^{\circ} \mathrm{C}$ and $40^{\circ} \mathrm{C}$. The percent lead removal efficiency by black and green STLs was found to be $98.4 \%$ and $98 \%$ at $25^{\circ} \mathrm{C}$, and $99.3 \%$ and $98 \%$ at $40^{\circ} \mathrm{C}$, respectively. The experimental data fit the Langmuir isotherm model well, with maximum adsorption of $101 \mathrm{mg} / \mathrm{g}$ and $83.3 \mathrm{mg} / \mathrm{g}$ at $40^{\circ} \mathrm{C}$ for back and green tea leaves, respectively. The results of this study indicate that STL was more effective in removing $\mathrm{Pb}$ (II) than conventional adsorbents such as activated carbon.

In concern with the treatment of organic pollutants, SD is one large group that can pose an environmental problem when industrial effluents are not treated efficiently before being discharged to streams. Hameed (2009) [65] has focused on the use of STL as a new non-conventional adsorbent for the adsorption of methylene blue (MB) dye solutions in a batch mode process at $30^{\circ} \mathrm{C}$. As a result, the Langmuir isotherm monolayer adsorption capacity was found to be $300.052 \mathrm{mg} / \mathrm{g}$. The adsorption removal of basic violet-10 dye (BV-10) from aqueous solution using black STL was the center of a research study conducted by Mohamed and Rahman (2013) [92]. Their equilibrium adsorption experiments were carried out at different temperatures at $\mathrm{pH} 6$. According to the data obtained from the Langmuir model, the maximum amount of BV-10 adsorbed by the black STL was $71.4 \mathrm{mg} / \mathrm{g}$ at $30^{\circ} \mathrm{C}$.

Similarly, adsorbent from agricultural by-product was the aim of research by Ramesh et al. (2014) [112], when they investigated the possibility of using the spent tea dust (STD) and raw coir pith (RCP) for the removal of methylene blue (MB) from aqueous solution using batch adsorption experiments. Batch experiments were carried out by placing $0.35 \mathrm{~g}$ of STD and $0.1 \mathrm{~g}$ of RCP separately in $100 \mathrm{ml}$ of aqueous solution containing $25 \mathrm{mg} / \mathrm{l}$ of $\mathrm{MB}$ and then agitating the mixtures at $130 \mathrm{rpm}$ with varying contact times from 2 to $240 \mathrm{~min}, \mathrm{pH}$ range from 2 to 10. Separation of adsorbent and adsorbate was done by centrifuge at $4,500 \mathrm{rpm}$ for $10 \mathrm{~min}$. The effects of the contact time, adsorbent dosage, and solution $\mathrm{pH}$ were studied at $27^{\circ} \mathrm{C}$. Based on the experimental results of this study, the following conclusion was drawn: the equilibrium adsorption was achieved in about $180 \mathrm{~min}$ with STD and 60 min with RCP, the optimal $\mathrm{pH}$ for favorable adsorption of MB is 7 by both adsorbents, and the adsorption capacities of STD and RCP were found to be $86.21 \mathrm{mg} / \mathrm{g}$ and $142.86 \mathrm{mg} / \mathrm{g}$, respectively. They also concluded that spent tea dust and raw coir pith could be employed as low-cost alternatives to commercial activated carbon for the removal of dyes.

A kinetic evaluation on the adsorptive removal of malachite green (MG) was carried out by Abul Hossain and Hossain (2014) [113] to evaluate the adsorptive removal of (MG) by used black tea leaves (UBTL) as a low-cost adsorbent in a batch mode system. Their results showed good adsorption capacity of UBTL to MG at $227.3 \mathrm{mg} / \mathrm{g}$ at $\mathrm{pH} 6.0$ and $30^{\circ} \mathrm{C}$.

In contrast to the batch mode process, Joodi and Abbas (2014) [114] have investigated the applicability of STL as an adsorbent for the removal of phosphorus pollutant ions from water using different design parameters by a fixed-bed column adsorption process. The experimental adsorption unit was conducted in order to test phosphorus ion removal from simulated synthetic aqueous solutions (SSAS). According to the data obtained, the removal of phosphorus pollutant ions was very much possible by STL adsorbents. Besides, it was reported that the highest percentage removal of phosphorus ions from (SSAS) was $97.68 \%$.

Another research study was conducted by Malko and Nuhoglu (2006) [115], when they used tea factory waste for the adsorption of $\mathrm{Cr}(\mathrm{VI})$ ions from aqueous solutions using a fixed-bed column. Experiments were carried out as a function of liquid flow rate, initial feed of $\mathrm{Cr}(\mathrm{VI})$ 
concentration, particle size, feed solution $\mathrm{pH}$, and bed depth. According to the data obtained, the maximum bed capacities for the tested flow rates were found to be $55.65,40.41$, and $33.71 \mathrm{mg} / \mathrm{g}$ at 5,10 , and $20 \mathrm{ml} /$ min, respectively. When the initial $\mathrm{Cr}(\mathrm{VI})$ concentration is increased from 50 to $200 \mathrm{mg} / \mathrm{l}$, the corresponding adsorption bed capacity appears to increase from 27.67 to $43.67 \mathrm{mg} / \mathrm{g}$. Breakthrough volume varies with bed depth and the treated volume considerably increases from about 4,200 to $11,800 \mathrm{ml}$ as bed depth increases from 5 to $30 \mathrm{~cm}$.

A continuous flow mode study using a fixed-bed column of a $130 \mathrm{~mm}$ height and a $12 \mathrm{~mm}$ internal diameter (ID) was carried out to evaluate the efficiency of STL as a low-cost adsorbent for the removal of CV from its aqueous solution. According to the data obtained, the removal of CV was possible by STL and very efficient up to the breakpoint time of about $7 \mathrm{~min}$., where the removal percentage accounted for 68 , when $\mathrm{CV}$ concentrations, bed height, and flow rate were optimized at $30 \mathrm{mg} / \mathrm{l}$, $20 \mathrm{~cm}$, and $5 \mathrm{ml} / \mathrm{min}$, respectively [18].

\section{Different Adsorbents Derived from Agricultural By-products/Wastes}

Biosorption of arsenic(V) by Moringa oleifera seed powder using a batch and continuous mode techniques was studied by Rajeswari and Pushpa (2014) [116]. Batch adsorption experiments were performed as a function of solution $\mathrm{pH}$, biosorbent dose, contact time, and initial metal concentration. In addition, the effect of bed height (4 and $8 \mathrm{~cm}$ ) and flow rate of $2 \mathrm{ml} \mathrm{min}^{-1}$ and $5 \mathrm{ml} \mathrm{min}^{-1}$ on the bio-sorption process by fixed-bed column was also investigated. The obtained results in this study showed that biosorbent dosage, $\mathrm{pH}$, volume of solution, metal ion concentration, and contact time highly affected the biosorption of As (V), and the maximum break-through time of $320 \mathrm{~min}$ was achieved at the operating condition of $2 \mathrm{ml} / \mathrm{min}$ influent flow rate and bed height of $8 \mathrm{~cm}$.

Today, rice husk $(\mathrm{RH})$ is one of the low-value agricultural by-products that have been used as source raw material for the synthesis and development of new phases and compounds, as well as natural sorbents for many metals and basic dyes. The rice husk is in the either untreated, treated, or in modified form using different agents $[5,50]$.

Kulkarni and Kaware (2015) [117] have investigated the removal of metal ions in a packed bed adsorption column using rice husk as cadmium sorbent. It was observed that increasing the initial cadmium concentration from $10 \mathrm{mg} / \mathrm{l}$ to $50 \mathrm{mg} / \mathrm{l}$ decreased exhaustion time from $830 \mathrm{~min}$ to $570 \mathrm{~min}$ and break point time decreased from $330 \mathrm{~min}$ to $120 \mathrm{~min}$. Also, with an increase in flow rate, exhaust time and break-through time decreased significantly. The optimum operating conditions (bed height, initial metal ion concentration, flow rate, and $\mathrm{pH}$ values) were found to be $50 \mathrm{~cm}, 30 \mathrm{mg} / 1,60 \mathrm{ml} / \mathrm{min}$, and 6 , respectively. The adsorption efficiency was obtained as $69 \%$ for optimum conditions.
On the other hand, there were a number of studies that focused on fixed bed column study for the removal of heavy metals such as $\mathrm{Pb}$ (II), $\mathrm{Cu}$ (II), and $\mathrm{Zn}$ (II) from wastewater by sodium carbonate-treated rice husk (NCRH). The experimental results of these studies allowed for the following conclusions: the NCRH was found to be an efficient media for the removal of heavy metals from wastewater. The column having a diameter of $2 \mathrm{~cm}$, with bed depth $10 \mathrm{~cm}$, metal ions concentration $10 \mathrm{mg} / \mathrm{l}$, and flow rate $10 \mathrm{ml} / \mathrm{min}$ could treat $2.281,2.22$ 1, and 2.151 of $\mathrm{Zn}(\mathrm{II}), \mathrm{Pb}(\mathrm{II})$, and $\mathrm{Cu}(\mathrm{II})$, respectively, at breakthrough. The results also reported that about $3.74 \mathrm{~g}$ and $3.90 \mathrm{~g}$ of $\mathrm{NCRH}$ were required per liter of $\mathrm{Pb}(\mathrm{II})$ and $\mathrm{Cu}$ (II) treatment, respectively [118-120].

George Z. Kyzas (2012) [121] studied the use of two types of coffee residues (treated and untreated) in removal of $\mathrm{Cu}$ (II) and $\mathrm{Cr}(\mathrm{VI})$ from aqueous solution. The effect of some parameter such as $\mathrm{pH}$, initial metal concentration, contact time, and agitation rate on the rate of adsorption were investigated. Equilibrium data were fitted to the Langmuir, Freundlich, and Langmuir-Freundlich (L-F) models. According to the experimental data of this study, the conclusions are summarized as follows: 1) the best correlation factor $\left(\mathrm{R}_{2}\right)$ was found to be 0.998 for the (LF) model, 2) the maximum agitation rate was found to be $140 \mathrm{rpm}, 3)$ the $\mathrm{pH}$ selected as optimum adsorption experiments was $\mathrm{PH} \mathrm{5.0,} \mathrm{and} \mathrm{4)} \mathrm{the} \mathrm{optimum} \mathrm{pH}$ found after desorption experiments was $\mathrm{pH} 2$ both for $\mathrm{Cu}$ (II) and $\mathrm{Cr}(\mathrm{VI})$.

Evaluation of coffee waste adsorbent for malachite green (MG) removal from aqueous solution was the purpose of another study conducted by Franca et al. (2010) [122]. The adsorbent was obtained by microwave activation system. The results of the experiment showed that the rate of adsorption was affected by the process conditions such as: adsorbent dose, solution $\mathrm{pH}$, and contact time. This study indicated that spent coffee grounds present great potential as an inexpensive and easily available alternative adsorbent for the removal of cationic dyes in wastewater treatment.

Most of the adsorption research studies concerning the remediation of dyes have been conducted in batch modes, which are generally very easy to apply in the laboratory and limited to the treatment of small quantities of wastewater [123]. The data obtained under batch conditions are generally not applicable to most treatment systems, i.e., column operations, where contact time in batch mode is too short to attain an equilibrium state in column systems [124]. In fact, it is very necessary to run a continuous flow process when needed to obtain basic engineering data [36, 125]. Besides, the continuous flow process is a low reagent handling and accordingly very low in operating cost and has the ability to adapt to versatile processes [126-127].

Tea and coffee wastes can be also used as radioactive heavy metal adsorbents. However, a few studies have addressed the potential use of tea and coffee wastes for the extraction of uranium from aqueous solutions. Uranium extraction from aqueous solution using dried and pyrolyzed tea and coffee wastes was the aim of [128]. 
The maximum adsorption capacity of uranium by tried tea and coffee wastes was found to be 59.5 and $34.8 \mathrm{mg} / \mathrm{g}$, respectively, at $291 \mathrm{~K}$.

\section{Production of Activated Carbon}

\section{Background}

Historically, porous carbons, especially activated porous carbons, constitute one of the most important types of industrial carbons and have been in use for thousands of years. Their use in water purification can be dated back to 2000 BC, when ancient Egyptians used charcoal to purify water for medicinal purposes. It was during World War I that a major development in the use of porous carbon began and there was no going back [129]. Newer and more technologies have since then developed both for the manufacturing and application of this versatile material [130].

In the 1940s, activated carbon was introduced for the first time as the main water industry's standard adsorbent for the reclamation of municipal and industrial wastewater to a potable water quality [2], while powder-activated carbon (PAC) was first produced commercially in Europe in the early $19^{\text {th }}$ century [131].

Today, AC can be available commercially, and different grades are found at the markets [132], and the major sources for the production of commercial activated carbon are still from coal, asphalt, and petroleum coke. It has been reported that about $60 \%$ of the production of activated carbon globally is obtained from coal [5]. These commercial AC substances actually require complexing agents to improve their removal performance for contaminant matters. However, their high cost is the most limiting factor of their use as adsorbents [133]. Therefore, in the last few years the growing need of researchers to search for alternatives and develop low-cost AC adsorbent materials from cheaper and locally available agricultureby products had to occur.

One main advantage of utilizing the agricultural (forestry) by-products/wastes is the ability to synthesize and produce cheap and eco-friendly $\mathrm{AC}$ as an alternative substitution for commercial AC, in addition to the ability of utilizing these precursors in the form of non-carbonized raw material in sorption processes. These agricultural byproducts/waste materials usually have no economic value. They, as alternatives, may present a disposal problem leading to environmental pollution. In the case of forestry by-products/waste, a huge quantity of leaves fall down on the ground as a result of a natural withering at the autumn seasons and thus create piles in public gardens and national forests. Therefore, considerable economic value would be attained from the conversion of these waste materials into AC [18].

Carbon-containing materials such as agricultural byproducts/waste are converted to AC through a process called activation, which is essentially composed of a two-phase process. Phase one requires a pyrolysis of agricultural by-products/wastes such as wood, coal, peat, fruit stones, and shells. It is a burn off of amorphous decomposition products (tars) that work on freeing the pore openings and increasing the number of pores. While in phase two, the enlargement of pores in the carbonized material is achieved [134]. They are considered one of the feasible alternatives both in terms of environmental and economical points of view.

\section{Carbonization Technologies}

Historically, hydrothermal carbonization (HTC) was discovered by Bergius in 1913, and has been rediscovered and further developed under the direction of Professor Antonietti, director of the Department of Colloid Chemistry at the Max-Planck Institute of Colloids and Interfaces in Golm/Potsdam (MPI). HTC is now being mentioned as a promising technology to convert biomass into multiple bioproducts: a solid fuel compared to brown coal; liquid fuel or bio-oil; as a soil amendment to increase soil fertility and crop yields; carbon material that could be either activated to work as an adsorbent for water purification or $\mathrm{CO}_{2}$ sorption and as a low-cost adsorbent or permeable reactive barrier for uranium(VI)-, copper-, and cadmium-contaminated waters; nanostructure carbon material, carbon catalyst, which could be used in the production of fine chemicals; and a carbon material that could increase fuel cell efficiency [135]. When compared to fermentation and anaerobic digestion, HTC is referred to as the most exothermic and efficient process for carbon fixation [136]. Therefore, HTC is now seen as a promising technology (also for $\mathrm{CO}_{2}$ sequestration). In addition, some feed stocks are toxic and cannot be converted biochemically. Microwave technology is gaining importance as a promising technology for research and industrial applications [137]. Microwave heating offers a potential means of cost reduction as it is capable of reducing the heating period, energy consumption, and gas consumption. Additionally, microwave irradiation may promote rapid and precise temperature control and compact equipment size. However, there are very few studies that report the use of microwave heating for preparation of activated carbon [138].

\section{Selection of Raw Materials for AC Synthesis}

The nature of the precursor (in addition to the method of activation) has a strong influence on the porous structure and the adsorption properties of the resulting AC [139]. Therefore, the preparation of AC usually requires the selection of the appropriate raw material, which in turn implies the consideration of inexpensiveness, an increase in carbon content, and a decrease in inorganic content (i.e., low ash). The high density of the precursor represents a considerable importance that it contributes to enhance structural strength of the carbon. Sufficient volatile content is also important, since porous chars which are essential for making $\mathrm{AC}$ are produced as a result of the evolution 
Table 3. Proximate and ultimate analysis of some low-cost adsorbents as reported in literature.

\begin{tabular}{|c|c|c|c|c|c|c|c|c|c|}
\hline \multirow{3}{*}{ Adsorbent type } & \multicolumn{8}{|c|}{ Characteristics } & \multirow{3}{*}{ Ref. } \\
\hline & \multicolumn{4}{|c|}{ Proximate analysis $(\%)$} & \multicolumn{4}{|c|}{ Ultimate analysis (\%) } & \\
\hline & FC & VM & Ash & $\mathrm{MC}$ & $\mathrm{C}$ & $\mathrm{H}$ & $\mathrm{N}$ & $\mathrm{O}$ & \\
\hline Raw Bagasse & 10.5 & 83.3 & 6.2 & na & 41.55 & 5.55 & 0.03 & 52.86 & [140] \\
\hline Bagasse AC & 84.5 & 13.6 & 1.9 & na & 64.12 & 1.25 & 0.34 & 34.29 & [140] \\
\hline Raw Rice Husk & 15.8 & 67.5 & 16.7 & na & 36.52 & 4.82 & 0.86 & 41.10 & [140] \\
\hline Rice Husk AC & 62.8 & 11.8 & 25.4 & na & 54.75 & 1.31 & 0.50 & 18.04 & [140] \\
\hline Coir pith AC & 34 & 53 & 11 & 12 & no & No & no & no & [42] \\
\hline Raw (Jatropha curcas L.) & 37.2 & 55.4 & 6.30 & 0.68 & 45.50 & 7.20 & 4.00 & 43.30 & [141] \\
\hline Date palm leaf & 9.7 & 68.0 & 15.2 & 7.1 & 40.8 & 6.0 & 0.63 & 35.2 & [40] \\
\hline Date palm rachis & 8.3 & 73.6 & 6.0 & 12.1 & 39.8 & 5.7 & 0.19 & 43.0 & [40] \\
\hline Date stones & 17.5 & 74.1 & 1.2 & 6.4 & 51.2 & 6.4 & 0.73 & 40.9 & [40] \\
\hline Raw tomato waste & 12.8 & 82.67 & 1.58 & 2.95 & 59.84 & 8.79 & 4.08 & 27.03 & [46] \\
\hline Tomato waste AC & 68.32 & 22.73 & 1.47 & 7.48 & 72.93 & 3.49 & 3.42 & 19.83 & [46] \\
\hline Waste tea & na & na & 4.29 & 5.88 & 52.72 & 6.34 & 2.61 & 38.15 & [142] \\
\hline Coconut shell & na & na & na & 1.43 & 88.18 & 1.32 & 0.40 & 9.87 & [143] \\
\hline Globe artichoke leaves & na & na & 3.41 & na & 55.22 & 2.86 & 2.6 & 31.28 & [144] \\
\hline Oak cups pulp AC & na & 71.0 & 6.7 & 11.5 & 48.91 & 6.85 & 1.31 & 42.81 & [145] \\
\hline Corn cob & na & 78.7 & 0.9 & 4.3 & 46.8 & 6.0 & 0.9 & 46.3 & [146] \\
\hline Almond shell & na & 80.3 & 0.6 & 10.0 & 50.5 & 6.6 & 0.2 & 42.69 & [147] \\
\hline Olive stones & 42.90 & na & 2.36 & 27.21 & na & $\mathrm{Na}$ & na & na & [58] \\
\hline
\end{tabular}

of volatiles during the carbonization step. One good example can be represented by softwood; an agricultural by-product/waste characterized by $40-45 \%, 55-60 \%$, $0.3-1.1 \%$, and $0.4-0.5 \mathrm{~kg} / 1$ in respect to the contents of carbon, volatile matters, ash, and density. Raw materials used for the preparation of AC vary with their application. Conventional raw materials in order of their importance as porous carbon production capacity, characteristics, and market are: wood, coal, lignite, coco-nut shell, peat, and others [129]. Some characteristics such as proximate and ultimate analysis as well as surface area and pore volume for different low-cost adsorbents examined by several studies are presented in Tables 3 and 4.

\section{Features of AC}

Activated carbons are black solid substances, disordered, and microporous forms of carbon, with very high porosities and surface areas. They are one type of substance that comprise a large and important class of porous solids. Besides, they have found a wide range of technological applications - particularly in water treatment where such substances work on the removal of inorganic and organic pollutants. This $\mathrm{AC}$ unique versatility comes from its high surface area, porous structure, high adsorption capacity, and surface chemical nature, which can be appropriately modified by physical and chemical treatments to enhance the extent of a given adsorption process [139]. This carbon can be partially oxidized when its pores need to enlarge. They resemble a granular or powdered charcoal and carbonaceous material [154] that has a porous surface structure, which provides it with a high surface area, harmlessness to the environment, and ease in operation [155]. They are characterized with an internal surface area of more than $400 \mathrm{~m}^{2} / \mathrm{g}$ and relatively high mechanical strength [154]. Activated carbon substances can be available in the form of either granular activated carbon (GAC) or powdered activated carbon (PAC). The GAC particle is almost greater than $0.1 \mathrm{~mm}$ in size (about the size of coarse sand) [14], while the PAC is composed of even smaller particles. Exact specifications vary, but GAC is generally said to have a larger internal surface area and smaller internal pores than PAC [154]. The PAC characteristic of fastness in adsorption rate made PAC more applicable in the past, but its difficulties in disposing and handling have made GAC a more popular alternative for most applications [154]. Experimentally, a comparative research study was carried out by Yadav et al. (2004) [156] using GAC and PAC as adsorbents for the retention of arsenic ions (As) from aqueous solution. The results of their analysis proved a much more adsorption capacity obtained by the GAC. Figure 5 shows the different 
Table 4. Surface area and pore volume results of AC produced from low-cost materials reported in literature.

\begin{tabular}{|c|c|c|c|c|c|}
\hline \multirow[b]{2}{*}{ Source of AC } & \multicolumn{4}{|c|}{ Properties } & \multirow[b]{2}{*}{ Ref. } \\
\hline & $\begin{array}{l}\text { BET surface } \\
\text { area }\left(\mathrm{m}^{2} / \mathrm{g}\right)\end{array}$ & $\begin{array}{l}\text { Micropore volume, } \\
\qquad \mathrm{V} \mu\left(\mathrm{cm}^{3} / \mathrm{g}\right)\end{array}$ & $\begin{array}{l}\text { Mesopore volume, } \\
\operatorname{Vm}\left(\mathrm{cm}^{3} / \mathrm{g}\right)\end{array}$ & $\begin{array}{c}\text { Total pore volume, } \\
\qquad \mathrm{Vp} \mathrm{cm}^{3} / \mathrm{g}\end{array}$ & \\
\hline Sugarcane bagasse & 1620 & 0.515 & 0.464 & 0.979 & [148] \\
\hline Banana frond & 847 & 0.169 & 0.557 & 0.726 & [149] \\
\hline Tomato waste & 722 & 0.201 & 0.275 & 0.476 & {$[46]$} \\
\hline Pumpkin seed hull & 737.9 & 0.301 & na & 0.370 & [138] \\
\hline Globe artichoke L. & 2038 & 0.608 & 1.80 & 2.466 & [144] \\
\hline (Delonix regia) & 2854 & 1.44 & 0.16 & 1.60 & [150] \\
\hline Tea seed shells & 1530 & 0.5989 & 0.1837 & 0.7826 & [151] \\
\hline Coffee ground & 1021 & 0.350 & 0.950 & 1.300 & [152] \\
\hline Cotton stalk & 594 & 0.280 & 0.030 & 0.381 & [153] \\
\hline Flamboyant pods AC & 2854 & 1.44 & 0.16 & 1.6 & {$[150]$} \\
\hline Posidonio oceanic(L.) & 1483 & 0.494 & 0.456 & 1.022 & {$[55]$} \\
\hline Olive stones & 368.3 & 0.12 & na & 0.20 & {$[57]$} \\
\hline
\end{tabular}

pore sizes and their estimated values in nanometer found within the AC granular; macro pores were more than 50 $\mathrm{nm}$, meso pores $2-50 \mathrm{~nm}$, and finally micro pore with less than $2 \mathrm{~nm}$ in value [157].

The characteristics of $\mathrm{AC}$ depend on the physical and chemical properties of the precursor (i.e., agricultural byproduct/waste) as well as on the activation method applied (chemical or physical). The structural properties of the resulting AC can be affected by a number of factors, such as time of activation, temperature of activation, and the oxidizing agent used in addition to the starting precursor [158]. The adsorption capacity of the activated carbon for a specific adsorbate varies strongly with the type of raw material and the processing techniques used [159].

\section{Methods of Preparation and Activation of Activated Carbon}

The production of the AC initially involves dehydrating the natural carbon-containing precursors (i.e., agricultural by-products/wastes) followed by carbonization at slowly

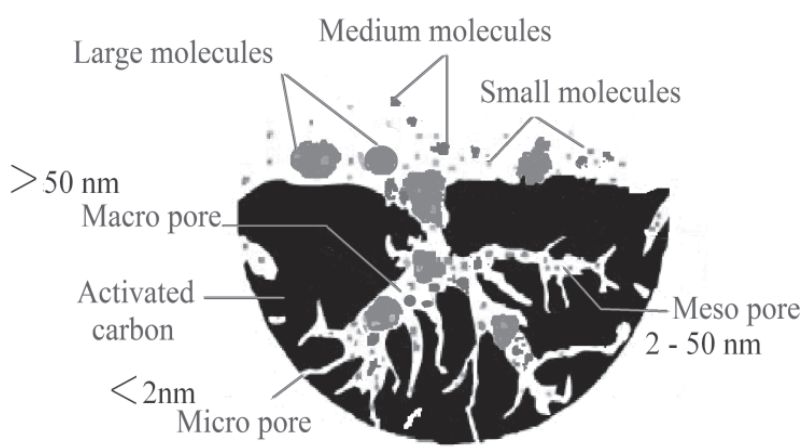

Fig. 5. Different pore structures of AC [157]. heating in the absence of air; it is also called pyrolysis. Next, the carbonized product is activated by either physical or chemical means; it is an important step to eliminate these in-pore deposited decomposed products and tars [134]. While the effectiveness of AC to act as adsorbents for a wide range of contaminants is well noted [160, 161], more and more research on $\mathrm{AC}$ modification is gaining prominence due to the need to enable ACs to develop an affinity for certain contaminants to outfit their removal from varying types of wastewater in the industries. It is therefore essential to understand the various factors that influence the adsorption capacity of AC prior to their modification so that it can be adapted to their specific physical and chemical attributes to enhance their affinities toward metal and inorganic and/or organic species present in aqueous solutions. These factors include the following: (i) specific surface area, (ii) pore-size distribution, (iii) pore volume, and (iv) the presence of surface functional groups. Accordingly, in terms of AC attainment, there are two famous basic methods for the preparation of ACs: physical and chemical activation [162].

Physical Activation: the source material is developed into activated carbon using hot gases. This generally is carried out by using one or a combination of carbonization in the presence of an inert gas to convert this organic precursor to primary carbon, which is a mixture of ash, tars, amorphous carbon, and crystalline carbon, and activation/ oxidation where high temperature in the presence of carbon dioxide, steam is required [163]. Undesirably, in the step of carbonization, some decomposition products or tars are deposited in the pores.

Chemical Activation: Prior to carbonization, the agricultural by-product/waste is impregnated with certain chemicals, which is typically an acid such as $\mathrm{H}_{3} \mathrm{PO}_{4}$, a strong base such as $\mathrm{KOH}$, and $\mathrm{NaOH}$ or a salt such as 
$\mathrm{ZnCl}_{2}$. This step is done to restrict the formation of tar; in this way a carbonized product with a well-developed porosity may be obtained in a single operation [139]. Then the agricultural by-product/waste is carbonized at lower temperatures $\left(450-900^{\circ} \mathrm{C}\right)$. It is believed that the carbonization/activation step proceeds simultaneously with the chemical activation. It is also believed that the chemical incorporated to the interior of the precursor particles reacts with the products resulting from the thermal decomposition of the precursor, reducing the evolution of volatile matter and inhibiting the shrinking of the particle; in this way the conversion of the precursor to carbon is high, and once the chemical is eliminated after heat treatment, a large amount of porosity is formed [164]. Chemical activation is preferred over physical activation owing to the lower temperature and shorter time needed for activating the material. The chemical activation method presents many advantages over the physical activation method and therefore it has been employed enormously in many studies when the preparation of AC from agricultural by-products/wastes is concerned. It was reported that the major advantages of the chemical activation compared to the physical activation are lower treatment temperatures and shorter treatment times [141]. In addition, activated carbon obtained by chemical activation exhibits a larger surface area and better developed mesoporosity than physical activation. Figure 6 shows the process of activated carbon manufacturing [131].

Many scientific papers concern the different methods of AC preparation and can be available and documented in scientific journals. This paper is intended to represent some of them and make them recognizable to the readers. Date stone as an agricultural by-product/waste was selected by Yahia (2002) [15] for testing a physical activation technique. These precursors were first dried in the oven, ground, and sieved. Then $\mathrm{ZnCl}_{2}$ is added to the sieved fraction. Trace of water is removed by heating in an oven and the impregnated stones are packed into long Pyrex tubes and placed in a furnace. After cooling, the final product is ground into a fine powder followed by washing thoroughly using water. Diluted $\mathrm{HCl}$ is added to the sample and let stand for $24 \mathrm{hr}$. Then the sample is filtered and washed with water again until the complete

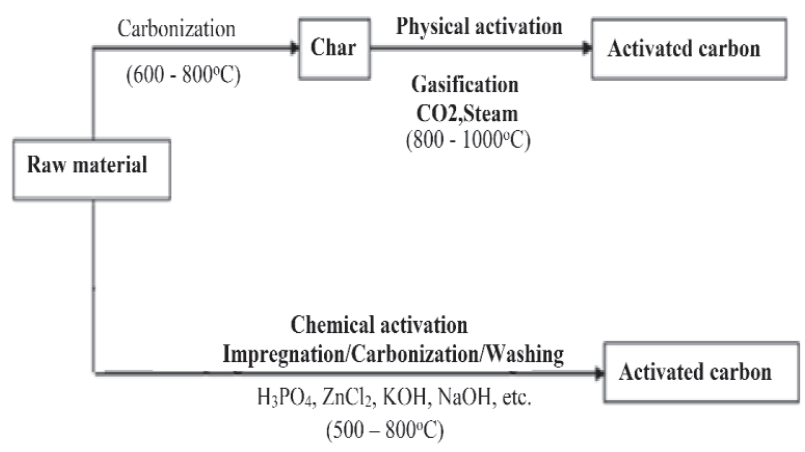

Fig. 6. Scheme of the process of activated carbon manufacturing [131]. disappearance of $\mathrm{Cl}$ ions in the filtrate. Yahia clarified that as very satisfying and anticipated results were attained using this method. In contrast to chemical activation, the most common method for the preparation of $\mathrm{AC}$ requires only one simple step, which is the heating treatment sometimes at a lower temperature than used in physical activation in the presence of some chemical agents.

A study was conducted by Zoulikha and Fatima (2008) to analyze the differences between a prepared $\mathrm{AC}$ from date stones by carbonization without the addition of an impregnating chemical and the same $\mathrm{AC}$ prepared by chemical activation with $\mathrm{ZnCl}_{2}$ or $\mathrm{KOH}$. According to the nature of the impregnating chemical, $\mathrm{AC}$ presented different porosities. Chemical activation with $\mathrm{KOH}$ and $\mathrm{ZnCl}_{2}$ resulted in an $\mathrm{AC}$ product having mesoporosity. However, activation with $\mathrm{ZnCl}_{2}$ developed microporisty more than activation with $\mathrm{KOH}$. Chemical activation of the date stones with both chemicals $\left(\mathrm{KOH}\right.$ and $\mathrm{ZnCl}_{2}$ ) produced $\mathrm{AC}$ with a high specific surface area of 880 and $1,030 \mathrm{~m}^{2} / \mathrm{g}$ for samples impregnated with $3.52 \mathrm{mmol}$ of $\mathrm{ZnCl}_{2}$ and pyrolysed at $873 \mathrm{~K}$ and samples impregnated with $9 \mathrm{mmol}$ of $\mathrm{KOH}$ and then pyrolysed at 1,073 K [139].

Carbon adsorbents prepared from Hulls of $S$. alterniflora were a targeted study carried out by Kunquan and Xiaohua (2009). They have reported a chemical activation of their stalks, which were initially crushed and sieved to $2 \mathrm{~mm}$. The sample was impregnated with $\mathrm{H}_{3} \mathrm{PO}_{4}$ for $1 \mathrm{hr}$ at room temperature. After drying, the sample was placed in a crucible and into a horizontal tubular furnace for carbonization at $250^{\circ} \mathrm{C}$ for $1.5 \mathrm{hr}$. The process was carried out under pure $\mathrm{N}_{2}$ gas flow of $80 \mathrm{~cm}^{3} / \mathrm{min}$. Temperature was subsequently raised at a rate of $10^{\circ} \mathrm{C} / \mathrm{min}$ until it reached $700^{\circ} \mathrm{C}$, where it was maintained for $2 \mathrm{hr}$. Based on data results, the process was very satisfying in obtaining efficient AC [165].

Hassan et al. (2011) [12] have found that in order to optimize the surface area of AC derived from Saudi Arabian date tree frond waste, the highest value of $1,139 \mathrm{~m}^{2} / \mathrm{g}$ surface area was obtained by the use of $60 \%$ concentration of $\mathrm{H}_{3} \mathrm{PO}_{4}$ as the most favorable concentration among $0.0 \%, 20.0 \%, 40.0 \%$, and $80.0 \%$. In contrast, the surface area of raw date fronds at $0.0 \%$ concentration of $\left(\mathrm{H}_{3} \mathrm{PO}_{4}\right)$ was $4.6 \mathrm{~m}^{2} / \mathrm{g}$. The results of thermo-gravimetric analysis (TGA) have revealed that the best temperature for activation was $400^{\circ} \mathrm{C}$. Authors have concluded that any temperature above this might affect the production of AC with a high surface area.

However, Hourieh et al. (1997) have studied the effect of $\mathrm{ZnCl}_{2}$ concentrations on the characteristics of $\mathrm{AC}$ derived from pistachio-nut shell. In this study, pistachio shells were chemically activated using $\mathrm{ZnCl}_{2}$ as an oxidizing agent and then physically activated by $\mathrm{CO}_{2}$ passed through water. As a result, ACs produced from pistachio shells treated with $40 \% \mathrm{ZnCl}_{2}$ and $40 \% \mathrm{HCl}$ at room temperature and then activated at $900^{\circ} \mathrm{C}$ for $90 \mathrm{~min}$ had higher surface areas of: (i) $3,256 \mathrm{~m}^{2} / \mathrm{g}$ of BrunauerEmmett-Teller (BET) surface area, (ii) $3,822 \mathrm{~m}^{2} / \mathrm{g}$ of Dubinin-Radushkevich (DR) surface area, and 1.36 $\mathrm{cm}^{3} / \mathrm{g}$ of DR micropore volume. In contrast, it was found 
that the $\mathrm{AC}$ produced from pistachio shells treated with $40 \% \mathrm{NaCl}$ and activated at $900^{\circ} \mathrm{C}$ for $90 \mathrm{~min}$ had $3,895 \mathrm{~m}^{2} / \mathrm{g}$ of BET surface area and $5,235 \mathrm{~m}^{2} / \mathrm{g}$ DR surface area and $1.86 \mathrm{~cm}^{3} / \mathrm{g}$ of DR micropore volume [166]. It was concluded that AC prepared from pistachio shells may be used for both gaseous and liquid adsorption applications, depending on the different activation conditions [167].

Foo and Lee (2010) have prepared AC with relatively high surface areas of $190 \mathrm{~m}^{2} / \mathrm{g}$ and pore volume of $0.0950 \mathrm{~cm}^{3} / \mathrm{g}$ from Parkia speciosa pods and concluded that these two attained surface area and pore volume of the produced AC were greatly dependent on the carbonization temperature; $600^{\circ} \mathrm{C}$ was the most appropriate among temperatures ranging from 450 to $650^{\circ} \mathrm{C}$. They also added that $\mathrm{AC}$ preparation was also dependent on mass ratio of acid to precursor; mass ratio of $1: 1$ was more favorable than 1:2. However, the yield of the final product decreased as the carbonization temperature increased [168].

\section{Application of Activated Carbon}

Different physical forms of activated carbon are produced depending on their application among these forms, the two most common forms are granular (GAC) forms to be used in adsorption columns and powder (PAC) forms for use in batch adsorption followed by filtration [131]. The main adsorbent used in industry is the activated carbon, which is involved in many fields such as separation of minerals, water, air, and gas purification (i.e., cigarette filters, motor vehicle exhaust controls), pollution treatment, de-colorization of tanning industrial wastewater, de-odorization of vegetable oils and fats, and food and pharmaceutical industries [16, 162, 169]. Activated carbon has been also used for gold and silver recovery and application as a catalyst and catalyst support.

In general, the primary application of activated carbon can be categorized into two groups of gas and liquid phase adsorption. Removal of colour, taste, and undesirable organic impurities from water has been one of the common liquid phase applications of activated carbons [170-172]. The reasons for making AC adsorbents widely used in the treatment of wastewaters is that these substances are characterized with exceptionally high surface areas that range from 500 to $1,500 \mathrm{~m}^{2} / \mathrm{g}$, welldeveloped internal microporosity structure as well as the presence of a wide spectrum of surface functional groups [173]. As an inert porous carrier substance, it is capable of distributing chemicals on its large hydrophobic internal surface, thus making them accessible to reactants [132]. They can be found in radioactive protection in nuclear plants [174]. In recent years, several scientific papers, technical works, reports, and literature reviews have focused on the utilization of AC derived from agricultural by-product/wastes for the adsorptive removal of HMs and $\mathrm{SD}$ from contaminated water. It was reported that more than 5,000 and about 6,500 works have been published for the removal of dyes and HMs, respectively $[5,175]$.

\section{Adsorption}

Adsorption is one of the separation methods for contaminant removal. The process is described as the adhesion of atoms, molecules or ions of gas, liquid, or solid on a surface material [176]. There are many advantages of adsorption, among which are the low space requirements for batch and continuous fixed bed units, simplicity of design and ease of operation, non-pollutant to water, no odor emissions, and the low cost of the adsorbent [57]. The adsorption process is generally classified as physical adsorption or chemical adsorption. Physical adsorption is achieved by Van der Waals forces, dipole interactions, and hydrogen binding. There is no electron exchange between adsorbent and adsorbate. Because there is no activation energy required for physical adsorption, the time needed to reach equilibrium is very short. Physical adsorption is a non-specific and a reversible process. While chemical adsorption results from the chemical link between adsorbent and adsorbate molecule, therefore it is specific as well as irreversible and chemical as well as electronic properties of adsorbent are changed. The binding between the adsorbent and adsorbate by covalent bond is called weak chemical adsorption, and that by ionic bonds is called strong chemical adsorption [131].

\section{Adsorption Mechanisms}

The adsorption process of the adsorbate molecules from the bulk liquid phase into the solid (adsorbent) phase is described by the following four steps:

1) The mass transfer of the adsorbate molecules across the external boundary layer toward the solid particle.

2) Adsorbate molecules are transported from the particle surface into the active sites by diffusion within the pore-filled liquid and migrate along the solid surface of the pore.

3) Solute molecule adsorption on the active sites on the interior surfaces of the pores.

4) The molecule gets approached inside the pores of the adsorbent as presented by Fig. 7 .

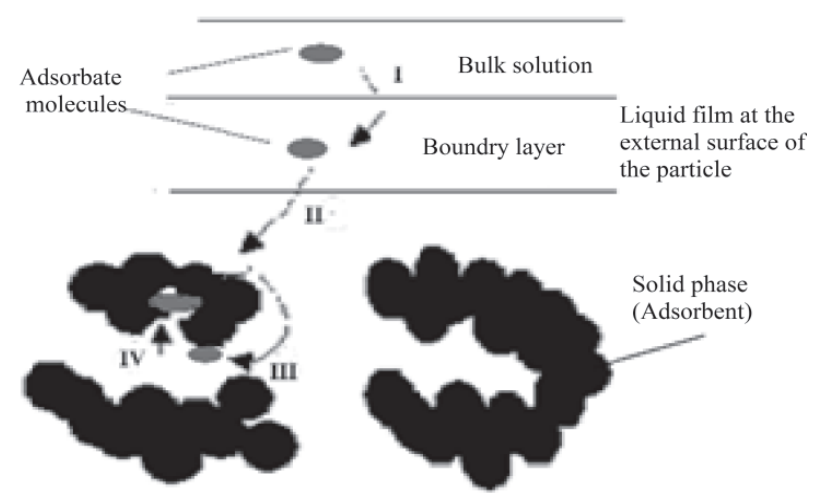

Fig. 7. Scheme of the mechanism of molecule adsorption using microporous adsorbent [177]. 
<smiles>CCC(C)C(CC)C(=O)O</smiles><smiles>CCCC(=O)C(C)C(C)CC</smiles>

Carboxyl

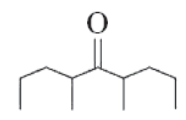

Crabonyl

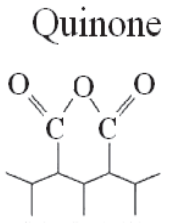

Carboxylic Anhydride<smiles>C=CC(C)C(C)C(C)CC</smiles>

Hydroxyl

$\mathrm{O}$

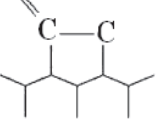

Lactone

Fig. 8. Simplified schematic of some acidic surface groups bonded to aromatic rings on $\mathrm{AC}$.

In contrast, an adsorption process occurs by a chemical link between the substance being absorbed (i.e., HM ion, $\mathrm{Pb}$ (II)) and the adsorbent (i.e., $\mathrm{AC}$ ), which usually in this case is pre-exposed to some chemical modifications to create some surface functional groups (i.e., acidic functional groups); the ones shown in Fig. 8 are the predominant types of surface functional groups [161, 178]. And thus in absorption, these functional groups hold the absorbed substance much more strongly, requiring much more energy to release the absorbed substance.

A cation exchange reaction is shown for a chemically modified AC, a cation exchange reaction occurs due to certain mechanisms where the metal cation exchange site with hydrogen ions previously was attracted as a whole carboxylic group. The carbon substance is with specific functional groups that are essential for the adsorption of heavy metal ions (i.e., $\mathrm{Pb}(\mathrm{II}), \mathrm{Cu}(\mathrm{II}), \mathrm{Mn}(\mathrm{II})$, etc.) due to the chelating attribute of these groups where alkalineearth metal cations can be integrated with the groups to form complexes as indicated in the following equation [132, 178-180].

$$
\mathrm{M}^{\mathrm{n}+}+\mathrm{n}(-\mathrm{COOH}) \leftrightarrow(-\mathrm{COO})_{\mathrm{n}} \mathrm{M}+\mathrm{nH}^{+}
$$

Some published reports pointed out that the sorption of $\mathrm{HM} /$ basic SD ions from solution sometimes is a mixed process involving more than a single species, and usually more than one species is being adsorbed into more than one type of surface site [181]. And the type of reaction often involved as a mechanism for the sorption of these $\mathrm{HM} / \mathrm{SD}$ ions is chemical, which is actually a reaction between the functional groups on the sorbent and the $\mathrm{HM} / \mathrm{SD}$ ions, or cation-exchange reaction (Fig. 9) due to the high cation-exchange capacity (CEC) of the sorbent [182]. Besides, some other mechanisms which may also be involved in the sorption of HM/SD ions are such as transport in the bulk of liquid phase, diffusion across the liquid film surrounding the solid particles, and diffusion into macro-pores or micro-pores has been shown in Figure 7. The chemical reaction for the adsorption of HMs onto a solid substance is described by the following simple equation [183]:

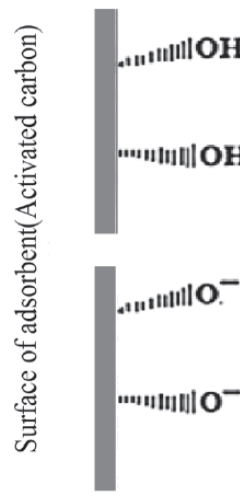

Before Adsorption

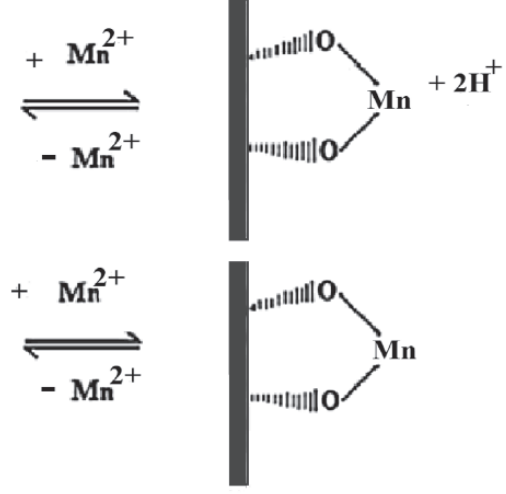

After Adsorption
Fig. 9. The surface functional groups and the reaction of sorption [184].

$$
\mathrm{M}+\mathrm{S}<------>\mathrm{MS}
$$

...where $\mathrm{M}$ is the metal-named sorbate, $\mathrm{S}$ is the solid sorbent, and MS is the metal-solid sorbent complex.

A new nonporous carbon from tomato paste waste (TWNC) for the removal of crystal violet (CV) from aqueous solution was prepared by Fuat et al. (2014) [46], which shows a possible mechanism for adsorption of $\mathrm{CV}$ onto TWNC as shown in Fig. 10.

On the surface of the AC sorbent primarily the sorption follows two mechanisms: chemisorption and physical adsorption. The amount of sorbate (M) that AC sorbent can accumulate is a key parameter for process engineering design. This capacity is determined by engineering an equilibrium sorption isotherm $[181,185]$ and has found

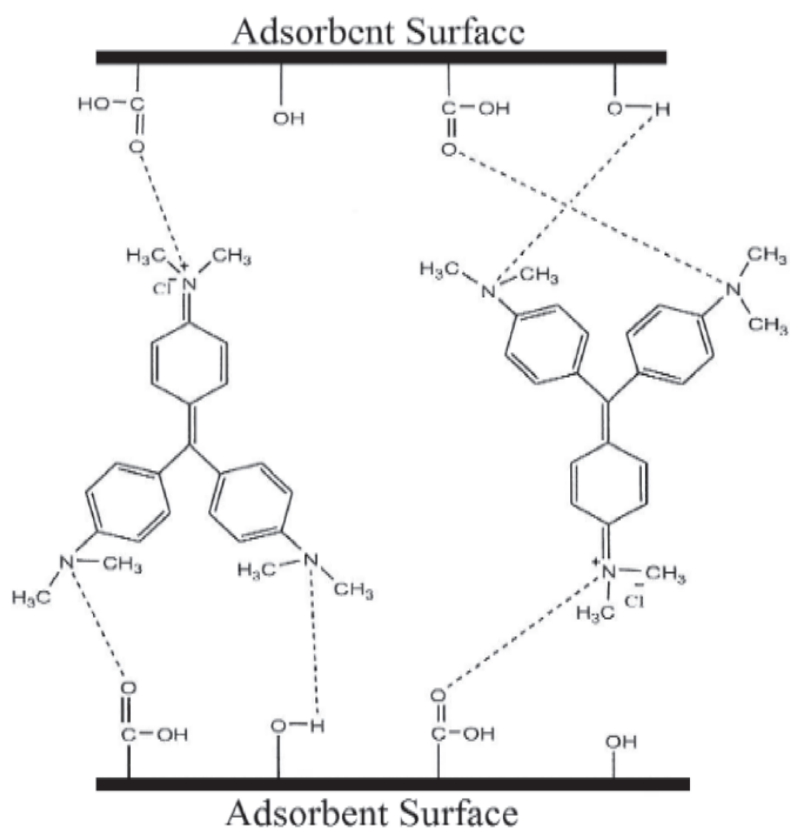

Fig. 10. Binding mechanism for the adsorption of CV molecules onto TWNC [46]. 
out that surface complexation, ion-exchange, diffusion, and precipitation of metal carbonate can be considered as other possible mechanisms. The significant differences between the amounts of metals desorbed from phosphoric clay suggest differences in their sorption mechanisms. Bio-sorption of HMs by non-living biomass of microbial or plant origin is a novel technique for the removal of these pollutants from aqueous solution. Due to unique chemical composition biomass sequesters the HM ion by forming complexes from solution [182].

The types of mechanisms occurring in $\mathrm{AC}$ and their mystery have been uncovered by the availability and utilization of very high tech instrumentations. Fourier transform infrared spectroscopy (FTIR) studies of adsorption demonstrated the main adsorption groups to be considered for the AC are carboxylic acid, phenols, pyrones, and the aromatic structure of the graphene layer. On the other hand, due to the cationic properties (i.e., MB), its charge is delocalized throughout the chromophoric system, although it is probably more localized on the nitrogen atoms [186].

Fig. 11 shows the mechanisms that may happen in the process of $\mathrm{MB}$ removal by an AC. The mechanisms were divided into electrostatic interactions (mechanism I), hydrogen bonding formation (mechanism II), electron donor-acceptor (mechanism III), and $\pi-\pi$ dispersion interaction (mechanism IV) [150]. While there has been a different study regarding biologically modified AC, the study has involved the utilization of $\mathrm{x}$-ray photoelectron spectroscopy and Fourier transform infrared spectroscopy (FTIR). They both uncovered the mysterious type of mechanisms involved in the adsorption of HMs on biomass of Padina $S p$. and Sargassum $S p$. before and after adsorption. They have indicated the functional groups in the cell wall of the biomass involved in bivalent metal bio-

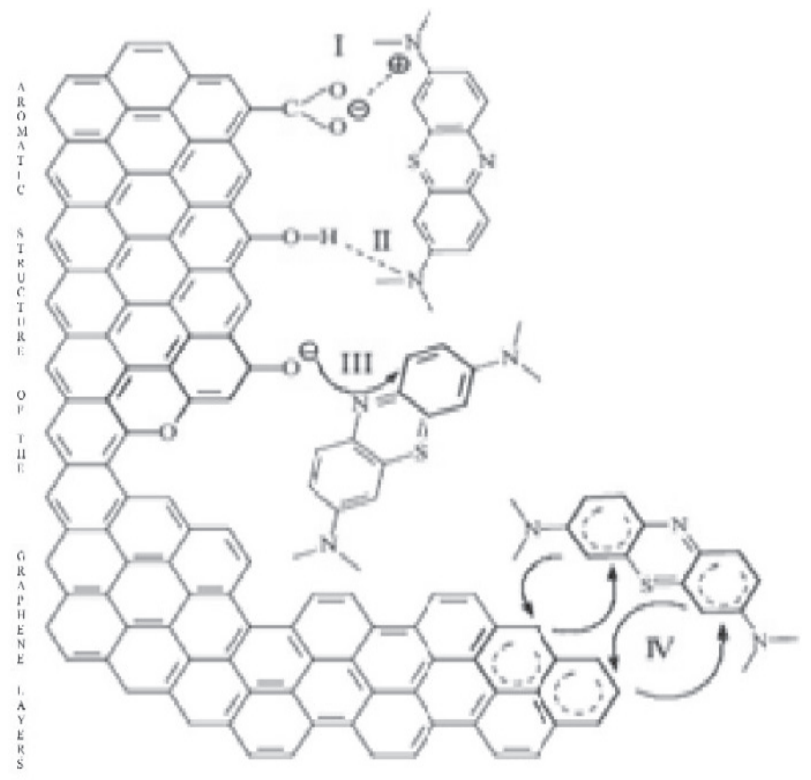

Fig. 11. Interaction mechanisms between $\mathrm{MB}$ and $\mathrm{AC}$ systems [150]. sorption, including carboxyl, ether, alcoholic, and amino groups. Sulfonate groups did not play a major role in the binding bivalent ions [183]. Once again, through the utilization of FTIR techniques, Alexandro et al., (2011) in their research study aimed to investigate the adsorption of $\mathrm{MB}$ onto AC produced from flamboyant pods (Delonix regia). They concluded that the functional groups present in the FT-IR spectra of AC, MB, and MB adsorbed onto AC allowed assessing the adsorption of MB, such as the SEM images. The mechanisms of electrostatic interactions, hydrogen bonding formation, electron donor-acceptor, and $\pi-\pi$ dispersion interactions confirm that different interactions may occur in the MB-AC system.

\section{Batch Mode and Fixed-bed Column Techniques}

The adsorption process of some undesirable polluted materials such as HM and SD on the ACs can be carried out in a laboratory using either batch mode or fixedbed column adsorption techniques. Batch laboratory adsorption studies provide useful information on the application of adsorption to the removal of specific pollutant constituents. In contrast, continuous column studies provide the most practical application of the adsorption process in wastewater treatments [154]. As stated in some scientific studies [187], the continuous adsorption process is more applicable and suitable in real water treatment industries due to its low operating cost and the ability of columns to adapt to versatile processes.

While batch reactors are easy for researchers to use in laboratory studies, they definitely are less convenient for pilot-scale work (i.e., industrial applications) [188]. Most of the reported studies on the adsorption of dyes (as well as HM) by AC were conducted in batch mode techniques [123, 187]. The sorption capacity of the sorbent, obtained from the batch equilibrium experiment, is useful for providing fundamental information about the effectiveness of the sorbate-sorbent system. Nevertheless, the data obtained from such a technique cannot in general be applicable to most treatment processes (i.e., the column process), as the contact time in batch process is not enough to attain equilibrium in continuous flow process $[124,126]$. A schematic diagram of batch sorption is shown in Fig. 12 [95], where the effluent contains $\mathrm{V}(\mathrm{L})$ of water and initial pollutant concentrations of $\mathrm{C}_{0}$, which is to be reduced to $\mathrm{C}_{1}$ in the adsorption process. In the treatment stage, $\mathrm{W}(\mathrm{g})$ adsorbent (pollutant-free) is added to the solution and the pollutant concentration on the solid changes from $\mathrm{q}_{0}=0$ (initially) to $\mathrm{q}_{1}$. The mass balance for the pollutant in the single-stage is given by the following:

$$
\mathrm{V}\left(\mathrm{C}_{0}-\mathrm{C}_{1}\right)=\mathrm{W}\left(\mathrm{q}_{0}-\mathrm{q}_{1}\right)
$$

Under equilibrium conditions: $\quad \mathrm{C}_{1} \rightarrow \mathrm{C}_{\mathrm{e}}$ and $\mathrm{q}_{1} \rightarrow \mathrm{q}_{\mathrm{e}}$ Then:

$$
\left(\mathrm{VC}_{0}+\mathrm{Wq}_{0}\right)=\left(\mathrm{VC}_{\mathrm{e}}+\mathrm{Wq}_{\mathrm{e}}\right)
$$




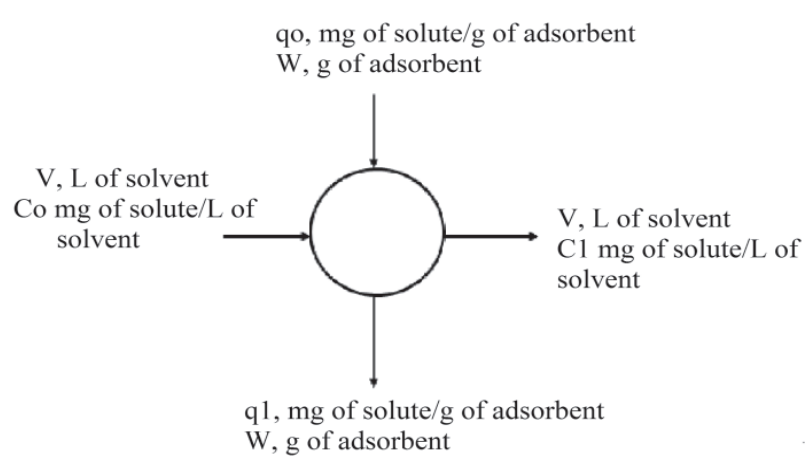

Fig. 12. A single-stage batch adsorbent [95].

And finally:

$\mathrm{W} / \mathrm{V}=\left(\mathrm{C}_{0}-\mathrm{C}_{1}\right) / \mathrm{qe}=\left(\mathrm{C}_{0}-\mathrm{C}_{\mathrm{e}}\right) /\left[\left(\mathrm{Q}_{0} \mathrm{~b} \mathrm{Ce}\right) /(1+\mathrm{bCe})\right]$

In contrast, the fixed-bed columns (Fig. 13) are widely used in various chemical industries because of their simple operation. Besides, with the high volume of wastewater to be treated, as compared to batch mode treatment, the continuous treatment is a lot more time efficient [187]. The fixed-bed column technique is used to determine the experimental breakthrough curve. A number of scientific articles have demonstrated that fixedbed column adsorptions using AC have been applied to remove organic contaminants for many years with very satisfying results $[33,36,187,189]$. The reason for this is that the accomplishment of high adsorption capacities in equilibrium occurs with the influent concentration rather the effluent concentration. In batch mode adsorption studies (static mode), the same solution remains in contact with a given quantity of the $\mathrm{AC}$ adsorbent. However, the adsorption process continues to proceed until reaching equilibrium between the solute concentration in solution and the solute adsorbed (i.e., SD) per unit weight of the $\mathrm{AC}$ adsorbents. In this case, equilibrium is static in nature, as it does not change further with time. Nevertheless, in dynamic column adsorption, the solution continues to enter and simultaneously leave the column, and equilibrium

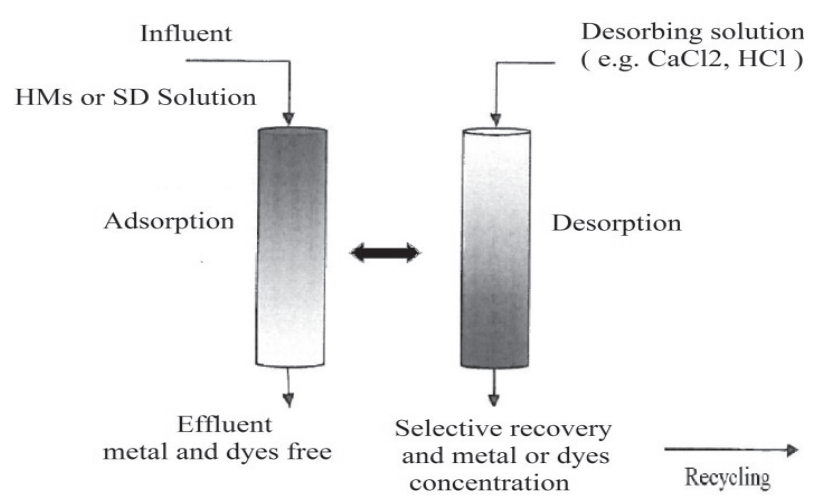

Fig. 13. Fixed-bed column sorption system principle (adsorption and desorption) [191]. will never be reached at any stage or time. Equilibrium has to be continuously established, as each time it meets the fresh concentration and hence equilibrium in column mode is termed as dynamic equilibrium [190].

\section{Affecting Factors on the Rate of Adsorption}

The number of physical and chemical factors that play an important role in the adsorption processes and influence the adsorption capacity of potential adsorbents during the adsorption process cannot all be conveniently shown here in this review paper. However, some studies chosen from literature were projected to demonstrate how strongly the efficiencies of these adsorbents are influenced by the physical and chemical characteristics of the solutions. The following paragraphs will represent the most common and effective factors.

\section{Effect of Solution $\mathrm{pH}$}

The $\mathrm{pH}$ value of the aqueous solution is an important controlling parameter in the adsorption process of HM/ SD using either batch mode process or fixed bed column. These $\mathrm{pH}$ values affect the adsorbent surface charge, the degree of ionization, and speciation of adsorbate during adsorption [192]. In general, the adsorption of most metals on AC adsorbents increased with the increase of $\mathrm{pH}$ [193194]. This was attributed to the fact that, at low $\mathrm{pH}(<4)$, the protonation of the active sites at carbon surface was enhanced and this refused the formation of links between cationic metals and protonated active sites. Some authors have reported that at higher $\mathrm{pH}$, metal complex forms and results in precipitation and therefore the separation may not be due to adsorption [195-196].

\section{Effect of Agitation Speed and Contact Time}

Equilibrium time is a very important element to study when considering an economical wastewater treatment application [197]. Simply put, there are three stages (phases) for the sorption process as follows: in the initial state the sorption process is very rapid and the rate of removal is higher because of the large amount of adsorbate attached to the sorbent within the first period time of adsorption. For the higher sorption rate at the beginning, this can be attributed to the presence of a larger surface area represented by the adsorbent and the availability of free active sites at the beginning time for the adsorption of adsorbate. After this period, as the contact time increases the sorption rate gradually becomes relatively slower and at some point in time, reached a constant value where no more adsorbate was removed from the solution (transition phase). Finally, the process attains plateau state (saturation phase). The lack of free active sites on the adsorbents at this time was the reason behind this behavior.

A number of research studies have also obtained similar results. Some of them have concluded that the 
results of the effect of exposure time for $\mathrm{CV}$ adsorption under shaking onto Chaetophora alga showed a rapid rate of adsorption in the first $3.0 \mathrm{~min}$, and the equilibrium state was attained almost after 15.0 to $20.0 \mathrm{~min}$ [198]. Other comparable results were obtained by the adsorption of some basic dye onto Citrullus Lanatus Rind [199], and the adsorption of $\mathrm{CV}$ from aqueous solutions using different natural materials [83]. In addition, Cengiz and Cavasl (2010) [200] and Awala and Jamal (2010) [201] have also obtained almost similar results by the adsorption of methyl violet (MV) onto dead leaves of Poisdonia Oceanica and by the adsorption of methylene blue (MB) onto feldspar respectively. The equilibrium has occurred by agitation at $130 \mathrm{rpm}$ during contact time of $20 \mathrm{~min}$, leading to a sorption percentage of $87.8 \%$. In terms of time creating the equilibrium, the data obtained can be obviously seen as shorter in contact time than in the batch process conducted at $90 \mathrm{rpm}$ [13]. In the process of dye colour adsorption, initially the dye molecule has to first encounter the boundary layer effect and then it has to diffuse from the boundary layer film onto adsorbent surface and then finally it has to diffuse into the porous structure of the adsorbents. This phenomenon will take relatively long contact time [202]. Therefore, a higher agitation speed will be required to improve the diffusion of the adsorbate toward the surface of the adsorbent.

\section{Effect of Flow Rate}

When dealing with optimizing the operating conditions of the continuous treatment of wastewater on an industrial scale, the flow rate of such influent wastewater is a very essential parameter to evaluate [36]. In general, the effect of flow rate on sorption of adsorbate material (i.e., dye molecules) onto adsorbents by varying the flow rates, while all other parameters keep constant at optimum values. The breakpoint time, as well as sorption efficiency of adsorbate, were lower at higher flow rates [18, 36, 187, 203]. It is clear that rapid uptake is noticed in the initial stages of flow rate and the rate of uptake starts to decrease thereafter and finally reaches saturation. As increasing the flow rate of the pollutant influent solution, the breakpoint curves become steeper and reach the breakpoint time faster to lower. This is attributed to the fact that as the flow rate becomes higher, the contact time between the adsorbate solutes and the adsorbent is minimized in time, and hence the adsorbate molecules do not have enough time to uptake the binding sites on the adsorbent surface or diffuse into the pores of the adsorbents, causing the adsorbate solutes to leave the column before equilibrium to occur and breakpoint time to be reached earlier. These results were corroborated with a number of reported findings [203-205].

\section{Effect of Initial Adsorbate Concentrations}

The effluents of different industries may have different dye concentrations. The initial dye concentration is one of the important factors that affect adsorption kinetics [199]. In a batch mode experiment planned for the study of kinetics of $\mathrm{CV}$ adsorption from aqueous solution using different agricultural by-products, Satish et al., (2011) [83] have proved that percentage sorption of $\mathrm{CV}$ from aqueous solution decreased but the amount of $\mathrm{CV}$ adsorbed per unit mass of adsorbent $(\mathrm{mg} / \mathrm{g})$ increased with the increase in CV concentration. They declared that a driving force created by the initial $\mathrm{CV}$ concentrations was the important factor to overcome all mass transfer resistance of the $\mathrm{CV}$ between the aqueous and solid phases. Therefore, a higher initial dye concentration of $\mathrm{CV}$ dye will definitely encourage the sorption process. In a similar mode technique, the effect of the initial $\mathrm{MB}$ concentration on the adsorption rate by coconut bunch waste (CBW) at adsorbent dosage of $0.20 \mathrm{~g}$ and mixing speed of $100 \mathrm{rpm}$ has been investigated by Hameed et al. (2008) [95]. During their study, the adsorption at different concentrations was rapid in the initial stages and gradually decreases with the progress of adsorption until the equilibrium was reached. The amount of $\mathrm{MB}$ adsorbed at equilibrium $\left(\mathrm{q}_{\mathrm{e}}\right)$ increased from 30.42 to $65.55 \mathrm{mg} / \mathrm{g}$ as the concentration was increased from (50 to $500 \mathrm{mg} / \mathrm{L}$ ). But the $\mathrm{MB}$ percentage removal decreased from 57 to $13 \%$. They declared the same conclusion of Satish et al. (2011) about the role of the driving force created by the initial concentration.

In a continuous adsorption mode process, the effect of initial concentrations of the adsorbate on the continuous adsorption process by varying the concentrations, while all other operating conditions kept constant, can attract attention that the breakpoint and exhaustion times would decrease. This result was obtained in literature dealing with the removal of basic red 46 by granular activated carbon [187], the removal of crystal violet (CV) by Citrullus lanatus rind [199], and the removal of (CV) by STL [18]. The findings were attributed to the increase in the driving force made by the increase of the influent adsorbate concentration, leading to quick saturation of the adsorbent active sites, which in turn lead to fast breakpoint and exhausted times, as corroborated with the clarification made by Goel et al. (2005) [206], Kandaswamy and Sirkrishna (2013) [36], and Abbas et al. (2012) [207]. The percentage of adsorbate removal is the highest at lowest initial adsorbate concentration. This is due to the slower transport caused by decreased diffusion coefficient or decreased mass transfer coefficient and the effect of a low concentration gradient [187, 208]. The slower transport gives the adsorbate molecules more time to bind to the adsorption sites, thus increasing the removal efficiency and leading to slow breakpoint and exhausted times.

\section{Effect of Bed Height}

The effect of bed height on sorption of adsorbate material onto adsorbents has been well studied by a number of investigators [36, 209-210]. It was observed that the breakpoint time, as well as sorption efficiency of adsorbates, were both lower at lower bed height. Experimental studies indicate that the breakpoint and 
exhaustion times increased with the increase of bed height of the adsorbent $[18,36,187]$. As the bed height increased, the adsorbate molecules would have more time to contact with the adsorbents, which in turn would result in a higher adsorbate molecule removal efficiency in the column. Besides, the increase in the bed height leads to a decrease in adsorbate solution concentration in the effluent at the same time. On the other hand, the slope of the breakpoint curve was decreased with increasing bed height, which resulted in a broadened mass transfer zone.

The mass transfer zone (MTZ) is a band within the fixed bed length along which the adsorption takes place. MTZ extends from the influent end toward the effluent end of the adsorbent bed. The activated carbon behind the MTZ is completely saturated with adsorbate at $C e=C \mathrm{i}[57,211-212]$. The length of the mass transfer zone is defined as $L M T Z$. When $L M T Z=$ bed depth, it becomes LCRIT, or the theoretical minimum bed depth necessary to obtain the desired removal (ACE, 2001). In general, it is desired to have short MTZ in fixed bed adsorption. Smaller particle size of the adsorbent, higher diffusion coefficients, and high strength of adsorbate adsorbent bonding (large capacity) reduce the length of MTZ. For ideal adsorption, MTZ is considered negligible and the system has plug flow behavior [211]. Figure 14 demonstrates the movement of (MTZ) in fixed bed and development of the breakpoint curve.

Hamdaoui (2006) [209] and Vijayaraghavan et al. (2004) [213] have both stated that with the increase in bed height, the mass of the adsorbents increase and thus the surface area would also increase, which in turn provides an increase in the active binding site numbers, leading to a larger sorption capacity. Foo and Hameed (2012) have both stated that at lower adsorbent bed height an axial dispersion phenomenon predominates and reduces the diffusion of adsorbate molecules [210]. Similar findings were obtained in research studies: one dealing with the removal of $\mathrm{CV}$ by Citrullus lanatus rind and Cyperus rotundus [36], and the other dealing with the removal of acid blue 92 and basic red 29 dyes by Euphorbia antiquorumL AC using a packed bed column [203].

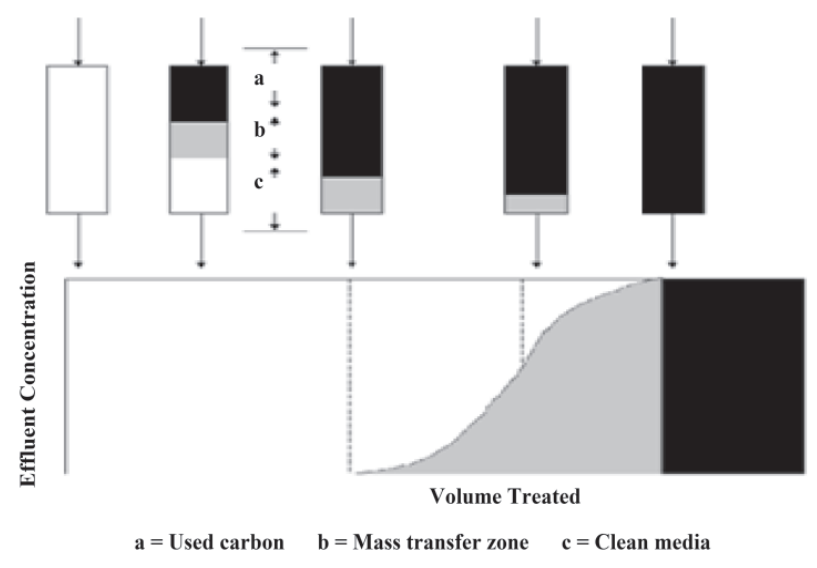

Fig. 14. Mass transfer zone and breakpoint curve in fixed bed adsorption [212].

\section{Effect of Adsorbent Dose}

On the other hand, when dealing with the batch mode technique, the amount of adsorbents (concentrations) is always and theoretically considered as a correspondent to the bed height factor. The percentage of adsorption increased with increases in adsorbent dosage, but the amount of molecules adsorbed per unit mass of adsorbent decreased [13]. As the amount of adsorbent increases, this definitely enhances the increase in the number of adsorption sites and thus increases the adsorbent surface area. A similar conclusion was stated in literature dealing with the removal of $\mathrm{CV}$ by Chaetophora elegans alga [198], adsorption of CV using different natural materials [83], and the removal of $\mathrm{Pb}$ (II) from aqueous solution on AC and modified AC prepared from dried water hyacinth plant [214]. In addition, Ashly and Thirumalisamy (2012) [35] and Bharathi and Ramesh (2012) [199] have also both obtained almost similar results from adsorption of CV and Rhodamine B (RHB) onto Acacia nilotica leaves, and a basic dye onto Citrullus lanatus rind, respectively.

\section{Effect of Particle Size}

The particle sizes of adsorbent materials is an important parameter in the adsorption process. For example, powder activated carbon (PAC) was better than granular activated carbon (GAC) in terms of metal adsorption capacity due to its larger pores and faster adsorption rate [215]. The larger pores of PAC allow by entrance the additional removal of these metals from their aqueous phase to take place, as Nadeem et al. (2009) [216] reported by applying three adsorbent particle sizes of $0.25,0.149$, and $0.074 \mathrm{~mm}$. Sorption is directly related to available surface area; hence the adsorbent with highest surface area (i.e., the lower particle size of $0.074 \mathrm{~mm}$ depicted as maximum removal percentage). The authors also attributed the result to PAC larger pores, permitting HMs to be more quickly adsorbed inside internal sites and thus fully occupying these active sites. Satish Patil et al., (2011) also reported that the adsorption capacity of CV dye decreased with particle size increases, and hence the percentage removal of dye also decreases when they using different natural materials as adsorbent for adsorption of CV dye [83].

\section{Case Studies on AC Derived from Agricultural By-product/Wastes}

$\mathrm{AC}$ has been proven to be an effective adsorbent for the removal of a wide variety of organic and inorganic pollutants dissolved in aqueous media. It is a widely used adsorbent in the treatment of wastewater due to its exceptionally high surface areas, well-developed internal microporosity structure, and the presence of a wide spectrum of surface functional groups [173]. Today, the major sources for the production of commercial ACs are still from coal, asphalt, and petroleum coke. But commercially available activated carbon is very expensive. Furthermore, regeneration using solution produces small 
additional effluent while regeneration by the refractory technique results in a $10-15 \%$ loss of adsorbents and its uptake capacity [217-218]. Also, these sources are nonrenewable and contribute to the high cost in the preparation of activated carbon [217]. It was reported that about $60 \%$ of the production of activated carbon globally today is obtained from coal [174]. Humphery and Keller (1997) estimated worldwide sales of AC at $\$ 1$ billion [161, 219]. Producing inexpensive $\mathrm{AC}$ is one of the main challenges in commercial manufacturing [220].

Always of prime concern is the cost of $\mathrm{AC}$, which is considered the cheapest adsorbents, and the cost per pound of AC prepared from agricultural by-product/waste is about $\$ 2$ (20 times less than the cost of zeolite) [221]. Then, the conservation of the environment clean and free from pollutants can also be of great concern. A moral step is put into consideration when scientists produce cheap $\mathrm{AC}$ to avoid the landfill disposal by agricultural wastes. When AC adsorbent material is obtained from low-cost and locally available agricultural by-product/wastes, it is considered an excellent alternative, especially when used for the treatment of wastewater for the removal of HM ions and SD molecules. These ACs have been successfully employed as an adsorbent for the removal of dyes by various researchers. For instance, a remarkable research study was conducted by Sulyman et al. (2014) [13], when they took advantage of carbonizing the waste leaves of Quercus robur l. oak trees; their withered leaves created piles of waste at public gardens and in national woods. The carbonized leaves were used for the removal of CV dye from an aqueous solution. The data obtained showed high removal efficiency, and the equilibrium state could be achieved in 20 minutes for different initial CV concentration. Finally, the adsorption process followed Freundlich isotherm with a linear regression value $\left(\mathrm{R}^{2}\right)$ of 0.9937

It is, therefore, essential to provide readers with understanding the various factors that influence the adsorption capacity of AC prior to their preparations so that it can be synthesized to their specific physical and chemical attributes to enhance their affinities toward SD/ HM species present in aqueous solutions. These factors include specific surface area, pore-size distribution, pore volume, and the presence of surface functional groups. In general, it has been reported that the adsorption capacity increases with specific surface area due to the availability of adsorption sites while pore size and micropore distribution are closely related to the composition of the AC, the type of raw material used, the degree of activation during the production stage, and the frequency of regeneration [222].

Activated carbons derived from agricultural-by products/wastes present comparable adsorption capacities and in some cases even better than those of commercially made AC. It was evident that adsorbents, soybean hulls modified by citric acid, maize bran, orange peel, and chitosan coated on acid-treated palm shell charcoal, coir pith, coir pith $\mathrm{AC}$, and oil palm shell $\mathrm{AC}$ have all demonstrated outstanding removal capacities as follows: [Cr(VI), $154.90 \mathrm{mg} / \mathrm{g}$ ], [Pb(II), $142.90 \mathrm{mg} / \mathrm{g}],[\mathrm{Ni}(\mathrm{II})$,
$158.00 \mathrm{mg} / \mathrm{g}$ ], [Cr(VI), $154.00 \mathrm{mg} / \mathrm{g}$ ], [Ni(II), 91.60 $\mathrm{mg} / \mathrm{g}],[\mathrm{Cd}(\mathrm{II}), 93.40 \mathrm{mg} / \mathrm{g}]$, and [(Pb(II), $95.20 \mathrm{mg} / \mathrm{g}$ ], respectively [223]. These adsorbents were found to have superior metal adsorbing capabilities when compared with commercial activated carbon (CAC), which had adsorption capacity as follows: $\mathrm{Cd}(\mathrm{II}), 146.00 \mathrm{mg} / \mathrm{g}$; $\mathrm{Cr}(\mathrm{VI}), 145.00 \mathrm{mg} / \mathrm{g} ; \mathrm{Cu}(\mathrm{II}), 15.47 \mathrm{mg} / \mathrm{g} ; \mathrm{Pb}(\mathrm{II}), 41.00$ $\mathrm{mg} / \mathrm{g}$; and $\mathrm{Zn}(\mathrm{II}), 20.00 \mathrm{mg} / \mathrm{g}$ [224]. Therefore, the lowcost adsorbents from agricultural by-products/wastes are good for substituting the very expensive commercial ones, and it is a great chance for those developing countries in particular which face numerous challenges that sometime restrict investments geared toward preserving the environment. Anirudhan and Radhakirshnan (2008) have demonstrated the adsorption of $\mathrm{Cu}$ (II) from aqueous solution using Tamarinda fruit shell TFS in the presence of (N, N'-methyl bis-acrylamide) as a cross-linking agent. Results showed that the obtained adsorption data $\left(R^{2}\right)$ at different temperatures has fit better with the Langmuir model than the Freundlich model. Copper $(\mathrm{Cu}(\mathrm{II}))$ ions adsorbed on TFS as a monolayer adsorption, and the increase of the adsorption capacity was followed by an increase in temperature [225].

Early in 1994, Srivastava et al. carried out an experimental work showing the adsorption of $\mathrm{Pb}$ (II) and $\mathrm{Zn}$ (II) ions onto lignin - a bio-material found as a waste product in paper factories. Their data analysis showed that the adsorption capacity of lignin for both ions was 1,865 $\mathrm{mg} / \mathrm{g}$ and $94.83 \mathrm{mg} / \mathrm{g}$ at $40^{\circ} \mathrm{C}$, respectively. Data also proved that those high adsorption capacities were a result of functional groups' presence on the surface of lignin. Besides, it was also concluded that since the adsorption capacity was increasing with temperature increase (from $-26.17 \mathrm{KJ} / \mathrm{mol}$ at $30^{\circ} \mathrm{C}$ to $-28.47 \mathrm{KJ} / \mathrm{mol}$ at $40^{\circ} \mathrm{C}$ for $\mathrm{Pb}$ (II) and from $-32.49 \mathrm{KJ} / \mathrm{mol}$ at $30^{\circ} \mathrm{C}$ to $-36.79 \mathrm{KJ} / \mathrm{mol}$ at $40^{\circ} \mathrm{C}$ for $\mathrm{Zn}$ ), it demonstrated that the process was endothermic [226].

An adsorption study of mercury $\mathrm{Hg}$ (II) from aqueous solution was studied by Namasivay and Kadirvelu (1999) using AC prepared from an agricultural by-product of coir-pith. The adsorption capacity of coir-pith carbon was $154 \mathrm{mg} / \mathrm{g}$ at $\mathrm{pH} 5.0$ [44].

Njoku et al. (2013) have investigated the feasibility of using pumpkin seed hull as a potential raw precursor for preparation of mesoporous AC (PSHAC) by micro-waveassisted $\mathrm{KOH}$ activation and a carbonization temperature of $750^{\circ} \mathrm{C}$ for the adsorption of 2,4-dichlorophenoxyacetic acid (2,4-D) using a batch technique. The BrunauerEmmett-Teller (BET) surface area was estimated to be $737.90 \mathrm{~m}^{2} / \mathrm{g}$. The adsorption isotherm in this study was analyzed by the non-linear Langmuir, Freundlich, and Temkin isotherm models. The data analysis showed that the adsorption of 2,4-D onto PSHAC was best represented by the Temkin isotherm model, with a maximum monolayer adsorption capacity of $260.79 \mathrm{mg} / \mathrm{g}$. The experimental result has also led to the conclusion that the solution $\mathrm{pH}$ played a key role by regulating the surface properties of PSHAC and the degree of ionization of 2,4-D, with the highest adsorptive uptake in the acidic medium [138]. 
Nasehir et al. 2011 have investigated the feasibility of using rice husk as a potential raw precursor for preparation of activated carbon (RHAC) $\mathrm{ZnCl}_{2}$ activation and a carbonization temperature of $700^{\circ} \mathrm{C}$ for the removal of $\mathrm{Cu}(\mathrm{II})$ from aqueous solution using a fixed-bed technique. The adsorption data in this study were fitted to three wellestablished fixed-bed adsorption models, namely the Adam-Bohart, Thomas, and Yoon-Nelson models. The results fit well to the Thomas and Yoon-Nelson models with correlation coefficient of R2 $\geq 0.96$, with a highest bed capacity of $34.56 \mathrm{mg} / \mathrm{g}$ [49].

Another paper investigating the adsorption properties of activated carbon prepared from pecan shells (PS276a) was studied by Reyad et al. (2002). This paper discusses the use of pecan shells as a raw material for the production of an activated carbon using a novel activating technique. This study also showed that the activation using phosphoric acid $\left(\mathrm{H}_{3} \mathrm{PO}_{4}\right)$ followed by sodium hydroxide $(\mathrm{NaOH})$ treatment produces a carbon (PS276a) with a large adsorption capacity toward solutes in aqueous solution. This adsorption capacity has been compared with that commercial adsorbent resin. A maximum adsorption of $\mathrm{Cu}$ (II) and $\mathrm{Sr}$ (II) onto PS276a was found to be $95 \mathrm{mg} / \mathrm{g}$ and $180 \mathrm{mg} / \mathrm{g}$ at $\mathrm{pH} 3.6$ and 8.5, respectively [159].

An AC derived from agricultural by-products/wastes was also studied by Madhava et al. in India (2009), where they have focused on synthesizing AC from hulls of the very widespread tree in India: ceiba pentandrea (ACCPH) and phaseolus aureus (ACPAH). These AC from ACCPH and ACPAH were used for removing mercury $(\mathrm{Hg}(\mathrm{II}))$ from aqueous solutions. Their experiment demonstrated that the adsorption process had removal capacities of $25.88 \mathrm{mg} / \mathrm{l}$ and $23.66 \mathrm{mg} / \mathrm{l}$, respectively, at an initial concentration of $\mathrm{Hg}$ of $40 \mathrm{mg} / \mathrm{l}$ at $\mathrm{pH}$ of 6.0 and contact time of $60 \mathrm{~min}$. They concluded that adsorption behavior of both AC types was explained on the basis of its chemical nature with more sulphonic functional groups, and adsorbed doses of $200 \mathrm{mg} / 50 \mathrm{ml}$ for the first. In contrast, the adsorption using AC from the ACPAH tree was effective at $\mathrm{pH} 7$ and contact time of $100 \mathrm{~min}$, and the adsorbed dose required by the second was $250 \mathrm{mg} / \mathrm{l}$ [227]. Similarly, Cheap AC from agricultural by-product/ waste was also the aim of another research study achieved by Kadirvelu et al. (2001), who investigated the feasibility of using AC from coir-pith being discarded as waste from coir processing industry, for the treatment of radiator manufacturing plating industrial effluents. The $\mathrm{AC}$ was expected to remove a number of $\mathrm{HMs}(\mathrm{Cu}, \mathrm{Hg}, \mathrm{Pb}, \mathrm{Cd}$, and $\mathrm{Ni}$ ) from wastewater. The results showed that the adsorption of the studied HMs increased with the increase in $\mathrm{pH}$ from 2 to 6 , and thereafter remained constant up to pH 10 [228].

The olive stone, a predominant product of the Mediterranean countries, has been utilized by Gharaibeh et al. (1998) in treatment of polluted water, instead of being a landfill disposal. The stones, when carbonized, have shown successful adsorption for a number of pollutants in aqueous solutions. They showed a better adsorption capacity of $128.20 \mathrm{mg} / \mathrm{g}$ toward $\mathrm{Cd}(\mathrm{II})$ ions than any reported results [229].

Another research study was conducted by Abudaia et al. (2013) when they used raw date stone materials for the synthesis of $\mathrm{AC}$ for the adsorption of $\mathrm{Cu}(\mathrm{II})$ and $\mathrm{Pb}$ (II) ions from aqueous solutions. Powder activated carbon (PAC) showed higher adsorption capacity and rate compared to GAC. Adsorption process data revealed that the initial uptake of both HMs was efficient at $\mathrm{pH}$ 6.5, and rapid and equilibrium was achieved within $30 \mathrm{~min}$ time for both forms of AC. The optimum parameters for this study were $50.0 \mathrm{mg} / 100 \mathrm{ml}$ of $\mathrm{Cu}(\mathrm{II})$ and $\mathrm{Pb}$ (II) concentrations, and around $1.0 \mathrm{~g} / 100 \mathrm{ml}$ of AC dose. The removal efficiency of $\mathrm{Cu}$ (II) and $\mathrm{Pb}$ (II) by $\mathrm{PAC}$ was $83 \%$ and $91 \%$, showing preference over GAC, which had a removal efficiency of $76 \%$ and $82 \%$, respectively [14].

Activated carbon adsorbent from agro-forestry waste was the aim of a research study achieved by Hesham et al. (2012). Their study focused on the preparation of AC in the form of PAC and GAC from such different local agroforestry wastes as marula fruit stones, jackalberry seeds, eembe seeds, efukwa shells, and eembu seeds. The $\mathrm{AC}$ was expected to remove $\mathrm{HM}$ ions such as $\mathrm{Pb}(\mathrm{II})$ and $\mathrm{Zn}$ (II) and dyes such as methylene blue (MB) and methyl orange (MO) from wastewater. Phosphoric acid of 50\% concentration was used for chemical activation of carbons obtained. Another aim of this study was the comparison of all carbons produced to commercially PAC and GAC forms. Table 5 shows the obtained results [158].

The pore size of $\mathrm{AC}$ can also be essential for researchers to consider when needing to pick an $\mathrm{AC}$ for use. Activated carbon must have pores larger than the largest molecule (i.e., HM/SD) to be adsorbed. However, $\mathrm{AC}$ is characterized with a broad range of pore size, which makes it more applicable than any other adsorbents (i.e., zeolite). The affinity of the AC adsorbent for some types of substances can be much greater than the affinity for others.

Table 5. Comparison of all carbons produced from different agro-forestry wastes for commercial PAC and GAC.

\begin{tabular}{|c|c|c|c|c|c|}
\hline \multirow{2}{*}{ Type of AC } & \multirow{2}{*}{$\begin{array}{c}\text { Form of } \\
\mathrm{AC}\end{array}$} & \multicolumn{4}{|c|}{ Percentage Removal (\%) } \\
\cline { 3 - 6 } & $\mathrm{Zn}(\mathrm{II})$ & $\mathrm{Pb}(\mathrm{II})$ & ${ }^{*} \mathrm{MO}$ & ${ }^{* *} \mathrm{MB}$ \\
\hline \multirow{2}{*}{$\begin{array}{c}\text { Commercial } \\
\mathrm{AC}\end{array}$} & Powder & 90 & 100 & 92 & 84 \\
\cline { 2 - 6 } & Granular & 89 & 100 & 87.5 & 92.2 \\
\hline \multirow{2}{*}{$\begin{array}{c}\text { Marula fruit } \\
\text { stones }\end{array}$} & Powder & 0.0 & -- & 84 & 83 \\
\cline { 2 - 6 } & Granular & -- & 100 & 78 & -- \\
\hline \multirow{2}{*}{$\begin{array}{c}\text { Jackalberry } \\
\text { seeds }\end{array}$} & Powder & 0.0 & 100 & -- & 84.4 \\
\cline { 2 - 6 } & Granular & -- & -- & -- & 83 \\
\hline \multirow{2}{*}{$\begin{array}{c}\text { Eembe } \\
\text { seeds }\end{array}$} & Powder & 60 & 100 & -- & 81.3 \\
\cline { 2 - 6 } & Granular & 0.0 & -- & -- & -- \\
\hline \multirow{2}{*}{$\begin{array}{c}\text { Efukwa } \\
\text { shells }\end{array}$} & Powder & 60 & -- & 84 & -- \\
\cline { 2 - 6 } & Granular & -- & -- & -- & -- \\
\hline \multirow{2}{*}{$\begin{array}{c}\text { Eembu } \\
\text { seeds }\end{array}$} & Powder & 60 & 100 & 84 & -- \\
\cline { 2 - 6 } & Granular & 91 & 100 & 87 & 81.25 \\
\hline
\end{tabular}

Note: $*=$ Methyl Orange, $* *=$ Methylene Blue 
As a result, when there is a stronger affinity for some of the molecules, the molecules having lesser affinity either get held with a smaller adsorption capacity or get released in favor of the molecules for which the affinity is greater. Activated carbon, which is neither fully hydrophobic nor hydrophilic, retains some adsorption area with affinity for both polar and non-polar molecules. Humidity and the presence of water molecules from the surroundings has a noticeable effect on AC because of this.

In many cases while conducting experiments, it can be noticed that desorbing of substances from AC occurs as steam condenses and the water displaces the substance. The affinity has to be considered as part of selecting the particular adsorbent. Carbon needs to be replaced every six months to five years, or when there is a bed fire, even though the replacement of other adsorbents such as zeolite is very rare. The frequency of replacements depends on the type of carbon, the frequency of regeneration, and the temperature at which it operates. The maximum temperature for desorption is less confining for $\mathrm{AC}$, which may be taken to a much higher temperature $\left(121.11^{\circ} \mathrm{C}\right.$ to $176.67^{\circ} \mathrm{C}$ ) without melting. Carbon frequently catalyzes oxidation reactions when the temperature gets above this range [221].

On the other hand, there have been a number of studies that focused on the preparation and characterization of AC from waste tea (WTAC) using different activating agents for the adsorption of dyes from aqueous solution [230233]. For instance, an AC produced from waste tea leaves with a novel activating agent such as potassium acetate for the sorption of acid blue 25 (AB25) dye in a batch mode technique was conducted by Auta and Hameed (2011). Their experimental studies showed that the rate of adsorption was found to be effected by the processing conditions such as initial dye concentration, contact time, temperature, etc. The Langmuir, Freundlich, Temkin, and Dubinin-Radushkevich (D-R) isotherm models were tested and the adsorption of AB25 dye onto WTAC was fitted to the Langmuir model and maximum adsorption capacity was found to be $203.34 \mathrm{mg} / \mathrm{g}$ [230].

Gao et al. (2013) have carried out experimental work demonstrating the utilization of tea (Camellia sinensis L.) seed shells for the preparation of AC for the adsorption of (MB) dye in a batch mode technique. Their data analysis showed the following: a high yield of $44.1 \%$ of $\mathrm{AC}$ was obtained with the chemical activation method using $\mathrm{ZnCl}_{2}$; the surface area (Brunauer-Emmett-Teller (BET)), of the obtained $\mathrm{AC}$ was found to be $1,530.67 \mathrm{~m}^{2} / \mathrm{g}$; the equilibrium adsorption results were compile using the Langmuir isotherm model and its maximum monolayer adsorption capacity was $324.7 \mathrm{mg} / \mathrm{g}$ for MB [151].

In a comparative study, Chandra et al. (2008) investigated the adsorption behavior of $\mathrm{Pb}$ (II) from aqueous solution system onto (GAC, derived from Agricultural byproduct/wastes) using batch mode and continuous mode in a packed bed column. Their experiment was carried out at constant temperature, dimension of column, and packed bed of GAC with variation of flows through the bed and concentration of $\mathrm{Pb}(\mathrm{II})$ solution. Results showed the effectiveness of such a process with adsorption capacity of $2.0132 \mathrm{mg} / \mathrm{l}$ feed concentration of $\mathrm{Pb}$ (II) at a hydraulic loading rate of $12 \mathrm{~m}^{3} / \mathrm{hm}^{2}$ and $0.6 \mathrm{~m}$ bed height, indicating that practical adsorption capacity using column bed of GAC is far less than batch mode results [154].

Gamzenur et al. (2013) investigated the adsorption properties of activated carbon prepared from brewed tea waste (TWAC) [234]. The activated carbon from a household waste is carried out by microwave activation using potassium carbonate $\left(\mathrm{K}_{2} \mathrm{CO}_{3}\right)$ as a chemical activating agent. The phenol was selected as a model solute in the study in order to evaluate the efficiency of the adsorbent tea waste activated carbon. Phenol adsorption studies were performed by the batch technique to obtain equilibrium. According to the experimental results of this study, the following conclusions were drawn: The surface area of the obtained waste tea activated carbon was $971.27 \mathrm{~m}^{2} / \mathrm{g}$, and the adsorption data of TWAC was fitted with the Freundlich isotherm model with a high regression coefficient of 0.9831 . All the results of this study also showed that brewed tea waste can be a suitable candidate for use as an activated carbon precursor, and microwave activation with $\mathrm{K}_{2} \mathrm{CO}_{3}$ yields carbon with good adsorptive properties.

Carbonized green tea (CGT) was effectively utilized by Muhammad et al. (2013) for the synthesis of AC, which was further utilized as an adsorbent for the removal of Remazol Brilliant Yellow (RBY) dye in a batch mode technique. Based upon the experimental results of this study, the following conclusions were drawn: CGT had the potential to be used as low-cost adsorbents for the removal of RBY, the equilibrium time period for removal of RBY onto CGT adsorbents was $7.0 \mathrm{hrs}$, and the maximum removal of the RBY dye occurred at $\mathrm{pH}$ was 9.5 [190].

Activated carbon materials were produced from used coffee grounds (CGCs) by chemical and physical activation using $\mathrm{KOH}$ and $\mathrm{CO}_{2}$. Maximum specific surface area (SBET) value was found to be $1,971 \mathrm{~m}^{2} / \mathrm{g}$ (Nobuhito, 2014). A similar adsorbent was the aim of another research study achieved by Jahin (2014) when he investigated the possibility of removing methyl red (MR) from aqueous solutions using chemical activation with concentrated $\mathrm{H}_{2} \mathrm{SO}_{4}$, followed by carbonization at three different temperatures $\left(400,500\right.$, and $\left.600^{\circ} \mathrm{C}\right)$. Batch experiments were carried out as a function of initial dye concentration, contact time, adsorbent dose, and $\mathrm{pH}$. Results showed that the maximum adsorption of MR dye by coffee residue occurred at $\mathrm{pH} 10$, and the removal efficiency was increased by decreasing the dye concentration and increasing the adsorbent dose [235].

Another work also used coffee waste for the production of $\mathrm{AC}$ by chemical activation using phosphoric acid and then carbonized respectively at $600^{\circ} \mathrm{C}$ and $700^{\circ} \mathrm{C}$ for 60 min. Based on the experimental results of this study, the following conclusions are drawn:

- The activated carbon obtained at $600^{\circ} \mathrm{C}$ and $700^{\circ} \mathrm{C}$ over one hour $\left(5^{\circ} \mathrm{C} / \mathrm{min}\right)$ in the presence of adjuvant percentage of about 5.678 and $12.78 \%$ gave respectively specific surfaces of 176 and $186 \mathrm{~m}^{2} / \mathrm{g}$. 
- The resulting adsorption capacities were respectively 52.63 and $55.56 \mathrm{mg} / \mathrm{g}$.

- The adsorption is compatible with Langmuir and Freundlich models with a correction factor $\mathrm{R}^{2}>0.92$.

- Adsorption equilibrium was reached after $40 \mathrm{~min}$ [236].

Agricultural by-product in Egypt ranged from 30-35 million tons annually, of which only 7 milion tons are used as animal feed and 4 million tons as organic manure, rice husk ash production by open-field burning and by combustion at $1,000^{\circ} \mathrm{C}$ for $4 \mathrm{hr}$ was conducted by Abdel Rahim and his coworkers (2015). Their results revealed that higher growth rates and larger crystals had been obtained by combustion at $1,000^{\circ} \mathrm{C}$ and the occurrence polymorphs of silica. Activation of rice husk ash with $(3.5 \mathrm{~N} \mathrm{NaOH})$, followed by the acid deposition technique, resulted in high silica in the agglomerate form with dimensions of $7 \mathrm{~nm}$ and the particle shape distribution was found to be

Table 6. Comparison between results of several studies for enhancing contaminant uptakes by AC.

\begin{tabular}{|c|c|c|c|c|c|}
\hline Activated carbon type & $\mathrm{CT},{ }^{\circ} \mathrm{C}$ & $\mathrm{BET}, \mathrm{m}^{2} / \mathrm{g}$ & $\mathrm{q}_{\mathrm{m}}, \mathrm{mg} / \mathrm{g}$ & Pollutant type & Ref. \\
\hline Rosa canina seeds & 500 & 799.2 & 47.2 & Methylene Blue & [239] \\
\hline Banana frond & 700 & 847.66 & 11.09 & Boron & [149] \\
\hline Globe artichoke L. & 500 & 2038 & 780 & Methylene Blue & [144] \\
\hline Posidonia oceanic L. & 873 & 1483 & 270.3 & Methylene Blue & [55] \\
\hline Tea seed shells & 500 & 1530.67 & 324.7 & Methylene Blue & [151] \\
\hline Brazilian pine- fruit-shell & 850 & 1436 & 328 & Procion Red MX 3B & [240] \\
\hline Spent tea leaves & 450 & 134 & 256.4 & Malachite Green & [233] \\
\hline Tomato paste waste & 500 & 722.17 & 68.97 & Crystal violet & [46] \\
\hline Waste tea & 760 & 830 & 200 & Cibacron yellow & [233] \\
\hline Mango seed & 500 & 1667.8 & - & Methylene Blue & [241] \\
\hline Rock Melon & $400-650$ & 38.77 & 14.28 & $\mathrm{Cu}(\mathrm{II})$ & [242] \\
\hline Rock Melon & $400-650$ & 38.77 & 5.62 & Ni (II) & [242] \\
\hline Rock Melon & $400-650$ & 38.77 & 3.38 & Cd (II) & [242] \\
\hline Date stones & 650 & 495.71 & 147.09 & Phenol P-Nitro & [243] \\
\hline Date stones & 600 & 495.71 & 179.62 & Phenol & [243] \\
\hline Date stones & 550 & - & 148 & Methylene Blue & [15] \\
\hline Date stones & 550 & 950 & 149.9 & $\operatorname{Pd}(\mathrm{II})$ & [244] \\
\hline Date stones & 600 & 950 & 91.3 & $\mathrm{Cd}(\mathrm{II})$ & [244] \\
\hline Olive Stones & 600 & 920 & 303 & Methylen Blue, & [245] \\
\hline Olive Stones & 600 & 920 & 217 & Rhodamine B Congo, & [245] \\
\hline Olive Stones & 600 & 920 & 167 & Red liste & [245] \\
\hline Olive Stones & $400-850$ & $953-1383$ & - & $\mathrm{Hg}(\mathrm{II})$ & [246] \\
\hline Eucalyptus. Bark & 500 & 1239 & - & $\mathrm{Cu}(\mathrm{II}), \mathrm{Pb}(\mathrm{II})$ & [247] \\
\hline Ziziphus spina-christi seeds & 700 & 914.23 & 172 & $\mathrm{Mn}(\mathrm{II})$ & [248] \\
\hline Alkaline impregnated hazelnut shell & 838 & 10.1 & 39.54 & $\mathrm{Cu}(\mathrm{II})$ & [249] \\
\hline Ceiba pentandra hulls & 200 & 521 & 25.88 & Hg (II) & [227] \\
\hline Ceiba pentandra hulls & 200 & 521 & 20.8 & $\mathrm{Cu}(\mathrm{II})$ & 250 \\
\hline Ceiba pentandra hulls & 200 & 521 & 19.5 & $\mathrm{Cd}(\mathrm{II})$ & [250] \\
\hline Rice husk & 700 & - & 34.56 & $\mathrm{Cu}(\mathrm{II})$ & [49] \\
\hline Sugarcane bagasse & 700 & 1620.29 & 138.46 & Ammonical nitrogen, & [148] \\
\hline Sugarcane bagasse & 700 & 1620.29 & 12.81 & Orthophosphate & [148] \\
\hline
\end{tabular}

Note: $\mathrm{CT}=$ Carbonization temperature, $\mathrm{BET}=$ Surface area, $\mathrm{q}_{\mathrm{m}}=$ Maximum capacity 
uniform. The value-added activated carbon of rice husk can also be simply produced by chemical activation of rice husk ash at $900^{\circ} \mathrm{C}$ for carbonization time of $120 \mathrm{~min}$ [237].

Activated carbon produced from rice husk and its characteristics is the aim of a research study achieved by Hariprasad et al. (2016). Produced rice husk activated carbon was carried out using physical and chemical activation methods as follows: the material selected is initially physically activated at a temperature ranging from $300^{\circ} \mathrm{C}$ to $700^{\circ} \mathrm{C}$ for $60 \mathrm{~min}$, and then the carbonized material thus obtained was soaked into $1 \mathrm{~N} \mathrm{KOH}$ at a $1: 1$ ratio overnight and was followed by physical activation at $300^{\circ} \mathrm{C}$ for $120 \mathrm{~min}$. The BET surface area was found to range from $11.9985 \mathrm{~m}^{2} / \mathrm{g}$ to $279.7752 \mathrm{~m}^{2} / \mathrm{g}$. Their studies indicated that the phenol adsorption capacity increased with increased temperatures. Maximum adsorption capacity was obtained at $25.6 \%, 66.66 \%, 87.4,94.6 \%$, and $95.8 \%$ at temperatures of $300,400,500,600$, and $700^{\circ} \mathrm{C}$, respectively [238].

\section{Conclusions}

In this review, details were provided to show that the study on low-cost adsorbents for HM and SD removal has attracted the attention of more scientists. A wide spectrum of carbonaceous adsorbent materials derived from either agricultural by-product or their wastes were found to be good alternative low-cost adsorbents to commercial AC for the removal of HM and SD from aqueous solutions. The most physical and chemical features, methods of synthesis in the form of raw materials or AC, were found to be of great interest to the reader to know. Either naturally achieved adsorbents or activated carbons via physical or/and chemical activation by any effective chemical perhaps attributed to its enriched content of carbonaceous substances, the availability of oxidizing agents (mostly as aqueous solutions), and the established nature of the technique that has been used for the past several decades.

A light was shed on the type of techniques that can be managed to eliminate undesirable polluted materials; these techniques were either batch mode or fixed-bed column adsorption techniques. It was made clear that the continuous adsorption technique was more applicable and suitable in real water treatment industries due to its low operating cost and ability of columns to adapt to versatile processes. While batch reactors are easy for researchers to use in laboratory studies, they definitely are less convenient for pilot-scale work. The sorption capacity of the sorbent, obtained from the batch equilibrium experiment, is useful in providing fundamental information about the effectiveness of the sorbate-sorbent system. Nevertheless, the data obtained from such a technique cannot in general be applicable to the column process. The review has covered some studies which were chosen from literature and projected to demonstrate how strongly the removal efficiency of HM/SD by these adsorbents were influenced by the physical and chemical characteristics of the solutions. This review also showed the most affecting factors on the rate of adsorption, which are $\mathrm{pH}$ solution, agitation speed and contact time, flow rate, bed height of adsorbent, initial concentration of adsorbate, mass, and particle size of adsorbent. These factors play an important role in the adsorption process.

\section{Recommendations}

In the last few years, it has been observed that the utilization of synthetic dyes (SD) such as methylene blue (MB), crystal violet (CV), basic violet-10 (BV-10), and malachite green (MG), and heavy metals (HMs) such as $\mathrm{Cu}(\mathrm{II}), \mathrm{Pb}(\mathrm{II}), \mathrm{Zn}(\mathrm{II}), \mathrm{Cd}(\mathrm{II})$, etc. in the field of scientific research increasingly have become a main axis of research. This practice is common, especially at universities and research centers where students and researchers at organic, analytical, microorganisms, medical, and pharmaceutical laboratories customarily intend to engage a number of them [18]. Conducting laboratory studies and research is considered a very essential part of academic and postgraduate studies where synthetic dyes are usually engaged in studies. However, a huge amount of colored liquids mostly derived from SD; as well as heavy metals solutions, are generated in the form of wastes. All of them usually find their ways disposed of in sinks and then to the main sewage network. So far in many countries, particularly in developing ones, the final reservoir is usually superficial waters represented by seawater and rivers. According to some annoying characteristics of those (SD) and/or HMs, they are considered problem makers to human health and

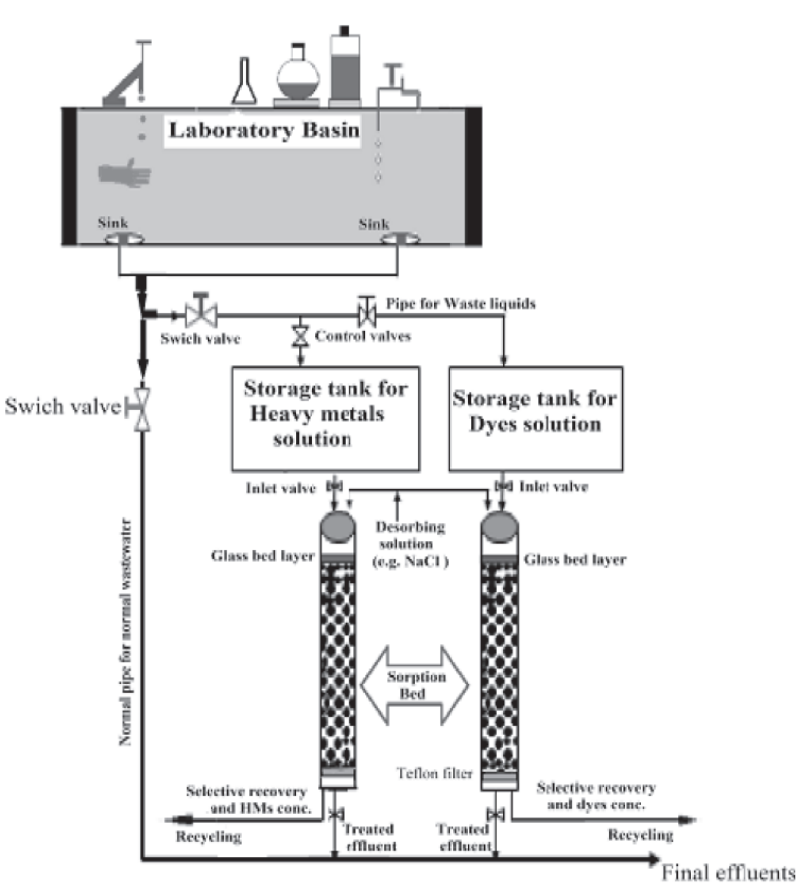

Fig. 15. A new proposed design of fixed-bed column filled with adsorbents for the adsorption of HMs and/or SD from waste liquids at university laboratories; multiple of columns can be used. 
aquatic animals. So their removal from effluents before being discharged to the environment and offering it for public use is very essential for the protection of health and the environment. The concept came into sight by the authors as a proposed design to be utilized at these workplaces mentioned above. In short, the concept involves the influents that are usually discharged in the form of batches, for the reason that after termination of any research studies at these sites, the residues become wastes and hence find their way drained through these proposed manageable bed columns filled with local activated carbon or dry plant and tree leaves prepared from agricultural byproducts/waste and forestry wastes for the treatment of colored and HM solutions. Fig. 15 shows the proposed manageable-bed column as a new design that can be made available at university laboratories.

\section{Abbreviations}

$\begin{array}{ll}\text { SD } & \text { Synthetic dyes } \\ \text { HM } & \text { Heavy metals } \\ \text { HTC } & \text { Hydrothermal carbonization } \\ \text { MPI } & \text { Max-Planck Institute } \\ \text { AC } & \text { Activated carbon } \\ \text { STL } & \text { Spent tea leaves } \\ \text { FAO } & \text { Food and agriculture organization } \\ \text { OMW } & \text { Olive mill wastes } \\ \text { IOC } & \text { International olive council } \\ \text { AT-STL } & \text { Alkali-treated spent tea leaves } \\ \text { GTL } & \text { Green tea leaves } \\ \text { MB } & \text { Methylene blue } \\ \text { CV } & \text { Crystal violet } \\ \text { STD } & \text { Spent tea dust } \\ \text { RCP } & \text { Raw coir pith } \\ \text { MG } & \text { Malachite green } \\ \text { UBTL } & \text { Used black tea leaves } \\ \text { SSAS } & \text { Simulated synthetic aqueous solutions } \\ \text { PAC } & \text { Powder activated carbon } \\ \text { GAC } & \text { Granular activated carbon } \\ \text { CEC } & \text { Cation-exchange capacity } \\ \text { MTZ } & \text { Mass transfer zone }\end{array}$

US EPA United States Environmental Protection Agency

PSHAC Pumpkin seed hull activated carbon

RHAC Rice husk activated carbon

ACCPH Activated carbon ceiba pentandrea

ACPAH Activated carbon phaseolus aureus

MO Methyl orange

BET Brunauer-Emmett-Teller

AB-25 Acid blue 25

TWAC Brewed tea waste activated carbon

CGT Carbonized green tea

RBY Remazol brilliant yellow

\section{References}

1. CONTRERAS L, SEPULVEDA L, PALMA C. Valorization of Agro-industrial Wastes as Biosorbent for the Removal of
Textile Dyes from Aqueous Solutions. International Journal of Chemical Engineering., Article ID 679352, 9, 2012.

2. GUPTA V.K. AND ALI I. Environmental Water Advances in Treatment, Remediation and Recycling. http://dx.doi. org/10.1016/B978-0-444-59399-3.00001-5, 2013.

3. GRAG V.K., KUMAR R., GUPTA R. Removal of Malachite Green Dye from Aqueous Solution by Adsorption Using Agro-industries Waste: a Case Study of Phosppis cineraria, Dyes Pigments, 62, 1, 2004.

4. United States, Environmental Protection Agency, EPA U.S., 2007.

5. SULYMAN M. Agricultural by-Products/Waste as Dye and Metal Ions Adsorbents: A Review, Research Inventy: International Journal of Engineering And Science,.6, 6, 01, 2016.

6. www.papercalculater.org

7. JUANG R.S., SHIAU R.C. Metal Removal from Aqueous Solutions Using Chitosan-Enhanced Membrane Filtration, J. Membr. Sci., 165 (2), 159. 2000.

8. AHLUWALIA S., GOYAL D. Microbial and Plant Derived Removal of Heavy Metals from Wastewater. Bioresource Technol. J., 98 (12), 2243, 2007.

9. SANCHEZ A.G., AYUSO E.A. Sorption of Zn, $\mathrm{Cd}$ and $\mathrm{Cr}$ on Calcite: Application to Purification of Industrial Wastewater. Miner. Eng. J., 15, 539, 2002.

10. [FAROOQ U., KOZINSKI J.A., KHAN M.A., ATHAR M, Biosorptionof Heavy Metal Ions Using Wheat Based Biosorbents. Bioresource Technol. J., 01, 5043, 2010.

11. BABEL S., KURNIAWAN T.A., Low-Cost Adsorbents for Heavy Metals Uptake from Contaminated Water: a review. J. Hazard. Mater. 97, 219, 2003.

12. AL-SWAIDAN H.M., ASHFAQ A. Synthesis and Characterization of Activated Carbon from Saudi Arabian Dates Tree's Fronds Wastes, 3rd International Conference on Chemical, Biological and Environmental Engineering, Ipcbee, 20, 2011.

13. SULYMAN M., NAMIENIK J., GIERAK A. Utilization of New Activated Carbon from an Oak Leaves for Removal of Crystal Violet from Aqueous Solution, Pol. J. Environ. Stud., 23 (6), 323, 2014.

14. ABUDAIA J.A., SULYMAN M.O., EL-AZABY K.Y., BEN-ALI S.M., Adsorption of $\mathrm{Pb}$ (II) and $\mathrm{Cu}$ (II) from Aqueous Solution onto Activated Carbon Prepared from Date Stones, International Journal of Environmental Science and Development, 4 (2), 2013.

15. ALHAMED Y.A.S., Preparation and Characterization of Activated Carbon from Dates' Stones In: The $6^{\text {th }}$ Saudi Engineering Conference, KFUPM, Dhahran, December 2002.

16. AMJAD H. EL-SHEIKH, ALAN P. NEWMAN, HAFID K. AL-DAFFAEE, SUKI PHULL, NEIL CRESSWELL., Characterization of Activated Carbon Prepared from a Single Cultivar of Jordanian Olive Stones by Chemical and Physicochemical Techniques. J. Anal. Appl. Pyrolysis., 71, 151, 2004.

17. RAFIE R.M., Removal of Heavy Metals from Waste Water Using Black Tea Waste, Arab J. Sci Eng, 37, 1505, 2012.

18. SULYMAN M., Fixed-bed Column Packed with Lowcost Spent Tea Leaves for the Removal of Crystal Violet from Aqueous Solution, $5^{\text {th }}$ International Conference on Environmental Science and Technology, Gdansk-Poland, 2014.

19. LIBRA J.A., RO K.S., KAMMANN C., FUNKE A., BERGE N.D., NEUBAUER Y., Hydrothermal carbonization of biomass residuals: a comparative review of the chemistry, processes and applications of wet and dry pyrolysis. Biofuels, 2 (1), 71, 2011. 
20. FOO K.Y., HAMEED B.H. Utilization of rice husks as a feedstock for preparation of activated carbon by microweve induced $\mathrm{KOH}$ and $\mathrm{K}_{2} \mathrm{CO}_{3}$ activation, Bioresource Technology, 102 (20), 9814, 2011.

21. BAILEY S.E., OLIN T.I., BRICKA M., ADRIAN D., A Review of Potentionally Low-Cost Sorbent for Heavy Metals. water res. 33, 2469, 1999.

22. TSAI W.T., LEE M.K., CHANG Y.M., J. anal. appl. pyrolysis 76, 230, 2006.

23. MARTINEZ M.L., TORRES M., GUZMAN C.A., MAESTRI D.M., Ind. crops prod. 23, 23, 2006.

24. LIM W.C., SRINIVASAKANNAN C., BALASUBRAMANIAN N. Activation of Palm Shells by $\mathrm{H}_{3} \mathrm{Po}_{4}$ Impregnation for High Yielding Activated Carbon. J. Anal. Appl. Pyrolysis, 88, 181, 2006.

25. HAIMOUR N.M., EMEISH S. Waste Manage. 26, 651, 2006.

26. TOLES C., MARSHALL W., JOHNS M., WARTELLE L., MCALOON A. Bioresour. Technol. 71, 87, 2006.

27. PUTUN E., UZUN B.B., PUTUN A.E. Bioresour. Ttechnol. 97, 701, 2006.

28. CRINI G. Non-Conventional Low-Cost Adsorbents for Dye Removal: A review. Bioresour. Technol., 97, 1061, 2006.

29. FIORENTIN L.D., TRIGUEROS D.E.G., MÓDENES A.N., ESPINOZA-QUIÑONES F.R., PEREIRA N.C., BARROS S.T.D., SANTOS O.A.A. Biosorption of Reactive Blue 5G Dye onto Drying Orange Bagasse in Batch System: Kinetic and Equilibrium Modeling. Chem. Eng. J., 163, 68, 2010.

30. KAUSHIK C.P., TUTEJA R., KAUSHIK N., SHARMA J.K. Minimization of Organic Chemical Load in Direct Dyes Effluent Using Low Cost Adsorbents. Chem. Eng. J., 155, 234, 2009.

31. KYZAS G.Z. A Decolorization Technique with Spent "Greek Coffee" Grounds as Zero-Cost Adsorbents for Industrial Textile Wastewaters. Materials J. 5, 2069, 2012.

32. KYZAS G.Z., LAZARIDIS N.K., MITROPOULOS A.C. Removal of Dyes from Aqueous Solutions with Untreated Coffee Residues as Potential Low-Cost Adsorbents: Equilibrium, Reuse and Thermodynamic Approach. Chem. Eng. J., 189-190, 148, 2012.

33. CAVAS L., KARABAY Z., ALYURUK H., DOGAN H., DEMIR G. Thomas and Artificial Neutral Network Models for the Fixed-bed Adsorption of Methylene Blue by a Beach Waste Posidonia Oceanic L. Dead Leaves. Chem. Eng. J., 171, 557, 2011.

34. DENIZ F., KARAMAN S. Removal of Basic Red 46 Dye from Aqueous Solution by Pine Tree Leaves. Chem. Eng. j., 170, 67, 2011.

35. ASHLY L.P., THIRUMALISAMY S. Adsorption of Hazardous Cationic Dyes from Aqueous Solutions onto Acacia nilotica L. Leaves as an eco Friendly Adsorbent, Sustain. Environ. Res., 22 (2), 113, 2012.

36. KANDASWAMY S.B., SRIKRISHNA P.T.R. FixedBed Column Studies on Bio-sorption of Crystal Violet from Aqueous Solution by Citrullus Lanatus and Cyperus Rotundus. Applied Water Science, DOI: 10.1007/s13201013-0103-4. adapted from http://www.springer.com. 2013.

37. JOHNS M.M., MARSHALL W.E., TOLES C.A. Agricultural by-Products as Granular Activated Carbons for Adsorbing Dissolved Metals and Organics, J. Chem. Technol. Biotechnol. 71, 131, 1998.

38. HAN R.P., ZOU W.H., YU W.H., CHENG S.J., WANG Y.F., SHI J. Bio-sorption of Methylene Blue from Aqueous Solution by Fallen Phoenix Tree`s Leaves. J. Hazard Mater, 141, 156, 2007.
39. IHSAN H.D. Adsorption of Methylene Blue Dye from Wastewater By Spent Tea Leaves, Journal of Kerbala University, 11 (3) Scientific, 2013.

40. YASSINE E.L., SOPHIE D., MEJDI J., GWÉNAELLE T., RACHID S. Measurement of Gaseous and Particulate Pollutants during Combustion of Date Palm Wastes for Energy Recovery. Aerosol and Air Quality Research, 12, 814, 2012.

41. RAGHUVANSHI S.P., SINGH R., KAUSHIK C. P. Kinetics study of methyene blue bye bioadsorption on baggase. Applied Ecology and Environmental Research., 2 (2), 35, 2004.

42. NAMASIVAYAM C., KADIRVELU K. Uptake of Mercury (II) from Wastewater by Activated Carbon from an Unwanted Agricultural Soild by-product: Coirpith, Carbon 37, 79, 1999.

43. FAOSTAT. On-line statistical database of the Food and Agricultural Organization of the United Nations, Available at http://www.apps.fao.org 2010.

44. BCHINI H., HSAYOUI S., ALOUI S. Gestion de la Matière Organique et Compostage des Palmes Sèches Dans le Milieu Oasien. Annales de l'INRAT 75, 299, 2002.

45. GOUAMID M., OUAHRANI M.R., BENSACI M.B. Adsorption Equilibrium, kinetics and thermodynamics of methylene blue from aqueous solutions using Date Palm Leaves, Energy Procedia 36, 898, 2013.

46. FUAT GU“ZEL, HASAN SAYG`ILI, GU“ LBAHAR AKKAYA SAYG ILI A, FILIZ KOYUNCU Decolorisation of aqueous crystal violet solution by a new nanoporous carbon: Equilibrium and kinetic approach. Journal of Industrial and Engineering Chemistry. 20, 3375, 2014.

47. RACHMA W., HUONG N., RIA M., CLAES N., MOHAMMAD J.T. Improvement of Biogas Production from Orang Peel Waste by Leaching of Limonene. Hindawi Publishing Corporation, BioMed Research International. Article ID 494182, 2014.

48. GUO Y.P, ROCKSTRAW D.A. Activated carbons prepared from rice hull by one-step phosphoric acid activation, Micropor. Mesopor. Mater, 100, 12, 2007.

49. NASEHIR K.E.M.Y., ISMAIL A., MUHAMAD F.L., OLUGBENGA S.B., MOHD A.A. Fixed-bed column study for $\mathrm{Cu}$ (II) removal from aqueous solutions using rice husk based activated carbon. International Journal of Engineering \& Technology IJET-IJENS, 11, 01, 2011.

50. NOOR SYUHADAH S., ROHASLINEY H. Rice Husk as Biosorbent: A Review, Health and the Environment Journal, 3, 1, 2012

51. CHUAH T.G., JUMASIAH A., AZNI I., KATAYON S., THOMAS CHOONG S.Y. Desalination. 175, 305, 2005.

52. REFFAS A., BERNARDET V., DAVID B., REINERT L., BENCHEIKH M.L., DUBOIS M., BATISSE N., DUCLAUX L. Carbons prepared from coffee grounds by $\mathrm{H} 3 \mathrm{PO} 4$ activation: characterization and adsorption of methylene blue and Nylosan Red N- 2RBL. J. Hazard. Mater, 175, 779, 2010.

53. NAKAMURA T., TOKIMOTO T., TAMURA T., KAWASAKI N., TANADA S. Decolonization of Acidic Dye by Charcoal from Coffee Grounds, Journal of Health Science, 49, 6, 520, 2003.

54. HIRATA M., KAWASAKI N., NAKAMURA T., MATSUMOTO K., KABAYAMA M., TAMURA T., TANADA I. Adsorption of dyes onto carbonaceous materials produced from coffee grounds by microwave treatment, J. Colloid Interface Sci. 254, 17, 2002

55. DURAL M.U., CAVAS L., PAPAGEORGIOU S.K., KATSAROS F.K. Methylene blue adsorption on activated 
carbon prepared from Posidonia oceanica (L.) dead leaves: kinetics and equilibrium studies. Chemical Engineering Journal. 168, 77, 2011.

56. PATIL P., SINGH S., YENKIE M. Preparation and Study of Properties of Activated Carbon Produced from Agricultural and Industrial Waste Shells. Research Journal of Chemical Sciences, 3 (12), 12, 2013.

57. RUBA A.F.A. Removal of Polyphenols from Olive Mill Wastewater using Activated Olive Stones, Thesis is Submitted in Partial Fulfillment of the Requirements for the Degree of Master in Water and Environmental Engineering, Faculty of Graduate Studies, An-Najah National University, Nablus, Palestine, 2012.

58. VLYSSIDES A.G., LOIZIDOU M., GIMOUHOPOULOS K. AND ZORPAS A. Olive oil processing wastes production and their characteristics in relation to olive oil extraction methods, Fresenious Environmental Bulletin, 7, 308, 1998

59. SALIM R., AL-SUBI M., ABU-SHQAIR I., BRAIK H. Removal of Zinc from Aqueous Solution by Dry Plant Leaves, Trans IChemE, 81 (Part B), 236, 2003.

60. YANG XIAOPING, CUI XIAONING Adsorption Characteristics of $\mathrm{Pb}$ (II) on Alkali Treated Tea Residue, Water Resources and industry, 3, 1, 2013.

61. SUNIL K.B., ARTI J. Removal of Copper (II) from Aqueous Solution Using Spent Tea Leaves (STL) as a Potential Sorbent, Water, 36 (3), 221, 2010.

62. SUNIL K.B., ARTI J. Sorptive Removal of Crystal Violet from Aqueous Solution Using Spent Tea Leaves: Part I Optimization of Sorption Conditions and Kinetics Studies, Acta Chem. Slov. 57, 751, 2010.

63. ZUORRO A., LAVECCHIA R., MEDICI F., PIGA L. Spent Tea Leaves as a Potential Low-cost Adsorbent for the Removal of Azo Dyes from Wastewater, Chemical Engineering Transactions, 32, 19, 2013.

64. [SUNIL K.B., ARTI J. Equilibrium and Thermodynamic Studies for Adsorption of Crystal Violet onto Spent Tea Leaves, Water, 4, 52, 2012.

65. HAMEED B.H. Spent Tea Leaves: ANew Non-Conventional and Low-Cost Adsorbent for Removal of Basic Dye from Aqueous Solution, J. Hazard Mater. 161, 753, 2009.

66. SINGH D.K., TIWARI D., SAKSENA D. Removal of Lead from Aqueous Solutions by Chemically Treated Tea Leaves, Ind. J. Environ. Health, 35, 169, 1993.

67. SALIM R., AL-SUBU M., SAHRHAGE E. Uptake of Cadmium from Water by Beech Leaves, J. Environ. Sci. Health, A27, 603 , 1992.

68. SALIM R., ABU-EL-HALAWA R. Efficiency of Dry Plant Leaves (Mulch) for Removal of Lead, Cadmium and Copper from Aqueous Solutions, Trans IChemE, Part B, Proc Safe Env Prot, 80B: 270, 2002

69. TAHIR H., SULTAN M., JAHANZEB Q. Remediation of Azo Dyes by Using Household Used Black Tea as an Adsorbent, African Journal of Biotechnology, 8 (15), 3584, 2009.

70. SALIM R., AL-SUBU M., QASHOA S. Removal of Lead from Polluted Water Using Decaying Plant Leaves, J. Environ. Sci. Health, A29, 2087, 1994.

71. AL-SUBU M.M., SALIM R., BRAIK H., SWAILEHI K.M. Removal of Dissolved Copper from Polluted Water Using Plant Leaves: Effects of Copper Concentration, Plant Leaves, Competing ions and Other Factors, Rev. Int. Contam Ambient, 17, 123, 2001.

72. SAYRA O., SALIM R., SAYRA S. Removal of Cadmium from Polluted Water Using Decaying Leaves, J. Environ. Sci. Health, A34, 835, 1991.
73. SALIM R. Removal of Nickel (II) from Polluted Water Using Decaying Leaves, J Environ Sci Health, A23, 183197 and 321-334, 1988.

74. ABDULLAH, M.M. AND PRASAD, A.G.D. Kinetic and equilibrium studies for biosorption of $\mathrm{Cr}(\mathrm{VI})$ from aqueous solution by potato peel waste. Research India Publications, 1, 2,51-62, 2009.

75. WITEK-KROWIAK A., SZAFRAN R.G., MODELSKI S. Biosorption of heavy metals from aqueous solution onto peanut shell as a low-cost biosorbent. Desalination, 265, 126, 2010.

76. SHEEN O.P. Utilization of Mango Leaf as Low-Cost Adsorbent for the Removal of $\mathrm{Cu}$ (II) Ion from Aqueous Solution, in partial fulfilment of the requirements for the degree of Bachelor of Science (Hons.) Chemistry May 2011, Universiti Tunku Abdul Rahman, www.eprints.utar. edu.my/83/1/CE-0805723-2011.pdf, 2011.

77. SUTEU D., MALUTAN T. Industrial Cellolinnin wastes as adsorbent for removal of methylene blue dye from aqueous solutions, Bioresources 8 (1), 427, 2013.

78. LIU Y., SUN X., LI B.U. Adsorption of Hg(II)and Cd(II) by ethylenediamine modified peanut shells. Carbohydrate Polymer, 81, 335, 2010.

79. BENAIISSA H., ELOUCHDI M.A. Removal of copper ions from aqueous solutions by dried sunflower leaves. Chemical Engineering and Processing, 46, 614, 2006.

80. BINDRA S., HOMAGAI P.L., POKHREL M.R., GHIMIRE K.N., Exhausted Tea Leaves - a low cost bioadsorbent for the removal of Lead (II) and Zinc (II) ions from their aqueous solution, J. Nepal Chem. Soc., 30, 2012.

81. CUIZANO N.A., LLANOS B.P., NAVARRO A.E. Application of marine seaweeds as lead(II) biosorbents: analysis of the equilibrium state. Revista de la Sociedad Química del Perú, 75 (1), 33, 2009.

82. FERRERO F.Dye removal by low cost adsorbents: hazelnut shells in comparison with wood sawdust. J. Hazard. Mater. 142, 144, 2007.

83. SATISH P., VAIJANTA D., SAMEER R., AND NASEEMS P. Kinetics of Adsorption of Crystal Violet from Aqueous Solution Using Different Natural Materials. International Journal of Environmental Sciences, 1 (6), ISSN 0976-4402, 2011.

84. MAHMOODI N.M., HAYATI B., ARAMI M., LAN C. Adsorption of textile dyes on Pine Cone from colored wastewater: Kinetic, equilibrium and thermodynamic studies. Desalination 268, 117, 2011.

85. VADIVELAN V., KUMAR K.V. Equilibrium, kinetics, mechanism, and process design for the sorption of methylene blue onto rice husk. J Colloid Interface Sci. 286, 90, 2005.

86. LAKSHMI U.R., SRIVASTAVA V.C., MALL I.D., LATAYE D.H. Rice husk ash as an effective adsorbent: Evaluation of adsorptive characteristics for Indigo Carmine dye. J Environ Manage 90, 710, 2009.

87. LIANG S., GUO X., FENG N., TIAN Q. Application of orange peel xanthate for the adsorption of $\mathrm{Pb}^{2+}$ from aqueous solutions. Journal of Hazardous Materials, 170, 425, 2009.

88. IHSAN HABIB DAKHILAdsorption of Chromium(Vi) from Aqueous Solutions using Low Cost Adsorbent: Equilibrium and Regeneration Studies, Journal of Engineering, 19, 11, 2013.

89. BENAISSA H. Effect of temperature on methylene blue sorption from aqueous solutions by almond peel: experimental studies and modeling, Thirteenth International Water Technology Conference, IWTC 13, Hurghada, Egypt, 377, 2009. 
90. MALKOC E., NUHOGLU Y. Investigations of Nickel (II) Removal from Aqueous Solutions Using Tea Factory Waste, J. Hazardous Materials, B127, 120, 2005.

91. HAMEED, B. H., MAHMOUD, D. K., AHMAD, A.L. Equilibrium modeling and kinetic studies on the adsorption of basic dye by a low-cost adsorbent: Coconut(Cocos nucifera) bunch waste, Journal of Hazardous Materials, 158, 65, 2008.

92. ABUL HOSSAIN M., RAHMAN M.D.A. Removal of Basic Violet 10 from Neutral Aqueous Solution by Adsorption on used black tea leaves, International Journal of Chemistry, 2, 83, 2013.

93. ABUL HOSSAIN M., HOSSAIN M.D.L. Kinetic study of Malachite Green adsorption on used black tea leaves from aqueous solution, International Journal of Advanced Research, 2, 4, 2014, 360-374, 2014.

94. JAIN S., JAYARAM R.V. Removal of basic dyes from aqueous solution by low-cost adsorbent: Wood apple shell (Feronia acidissima), Desalination 250, 921, 2010.

95. HAMEED B.H., KHAIARY M.I.E. Sorption kinetics and isotherm studies of a cationic dye using agricultural waste: Broad bean peels, J. Hazard. Mater. 154, 639, 2008.

96. DJELLOUL C., HAMDAOUI O. Dynamic adsorption of methylene blue by melon peel in fixed-bed columns, Desalination and Water Treatment, doi: 10.1080/19443994.2014.963158, 2014.

97. BABAKHOUYA N., BOUGHRARA S., ABAD F. Kinetics and Thermodynamics of Cd(II) Ions Sorption on Mixed Sorbents Prepared from Olive Stones and Date Pit from Aqueous Solution, American Journal of Environmental Sciences, 6 (5), 470, 2010.

98. AYHAN DEMIRBAS. Agricultural Based Activated Carbons for the Removal of Dyes from Aqueous Solutions: A Review, J. Hazad. Mater, doi: 10.1016/j.hazmat.12.114, 2009.

99. HANAN E. OSMAN, REHAN K. BADWY, HANAN F. AHMED. Usage of Some Agricultural By-Products in the Removal of Some Heavy Metals from Industrial Wastewater, J. Phyt., 2 (3), 51, 2010.

100. COELHO T.C., LAUS R., MANGRICH A.S., DE FAVER V.T., LARANJEIRA M.C.M. Effect of Heparin Coating on Epichlorohydrin Cross-Linked Chitosan Microspheres on the Adsorption of Copper (II) Ions. React Funct Polym, 67, 468, 2007.

101. DAVID N., HORN S. Chemical Modifications of Lignocellulosic Materials, Marcel Dekker Inc., New York, 97, 1995.

102. GARCIA-VALLS R., HATTON T.A. Metal Ion Complexation with Lignin Derivatives, Chem. Eng. J., 94, 99, 2003.

103. LASZLO J.A., DINTZIS F.R. Crop Residues as Ion Exchange Materials. Treatment of Soybean Hull and Sugar beet Fiber (Pulp) with Epichlorohydrin to Improve Cation Exchange Capacity and Physical Stability. J. Appl. Polym. Sci., 52, 521, 1994.

104. RAZMOVSKI R., SCIBAN M. Biosorption of $\mathrm{Cr}(\mathrm{VI})$ and $\mathrm{Cu}(\mathrm{II})$ by Waste Tea Fungal Biomass. Ecol. Eng. 34 (2), 179, 2008.

105. WAN X., LI D., ZHANG Z. Green Tea and Black Tea. In: Tea and Tea Products: Chemistry and Health-Promoting Properties, Ho, C.T., J.K.Lin and F. Shahidi (Eds.).CRC Press, Boca Raton, FL., ISBN: $9780849380822,1,2008$.

106. HARLER C.R. Tea Manufacture. Oxford University Press, New York., 108, 1963.

107. TAN W.T. Copper(II) Adsorption by Waste Tea Leaves and Coffee Powder, Pertanika, 8 (2), 223, 1985.
108. ORHAN Y., BUEKGUENGOER H. The Removal of Heavy Metals Using Agricultural- Wastes, Wat. Sci. Technol., 28 (2), 247, 1992.

109. ATTIA H.G. A comparison between cooking tea-waste and commercial activated carbon for removal of chromium from artificial wastewater. Journal of Engineering and Development, 16 (1), ISSN 1813-7822, 2012.

110. HOSSAIN M.A., MIKIO K., YOSHIMASA M., SHIGERU M. Kinetics of $\mathrm{Cr}(\mathrm{VI})$ Adsorption on Used Black Tea Leaves, J. Chem. Eng, Jpn. 38 (6), 402, 2005.

111. ZUORRO A., LAVECCHIA R. Adsorption of $\mathrm{Pb}(\mathrm{II})$ on Spent Leaves of Green and Black Tea. American Journal of Applied Sciences 7 (2), 153, 2010.

112. RAMESH S.T., GANDHIMATHI R., ELAVARASI T.E., ISAI T.R., SOWMYA K., NIDHEESH P.V. Comparison of Methlene Blue Adsorption from Aqueous Solution using Spent Tea Dust and Raw Coir pith. Global Nest Journal, 16 (1), 146, 2014

113. ABUL HOSSAIN M., HOSSAIN M.D.L. Kinetic study of Malachite Green adsorption on used black tea leaves from aqueous solution. International Journal of Advanced Research, 2 (4), 360, 2014.

114. JOODI A.S., ABBAS M.N. Profiting from Cooked Tea Leaves Waste in Eco-Friendly Method, Advances in Research, 2 (3), 179, 2014.

115. MALKOC E., NUHOGLU Y. Fixed bed studies for the sorption of chromium(VI) onto tea factory waste. Chemical Engineering Science, 61, 4363, 2006.

116. RAJESWARI M., PUSHPA A. Continuous Biosorption Of Arsenic By Moringa Olefera In a Packed Column, International Journal of ChemTech Research, 6, 7, 3603, 2014.

117. KULKARNI S.J., KAWARE J.P. Analysis of Packed Bed Adsorption Column with Low Cost Adsorbent for Cadmium Removal", Int. J. of Thermal \& Environmental Engineering. 9 (1) 17, 2015.

118. KUMAR U., ACHARYA J. Fixed Bed Column Study for the Removal of Copper from Aquatic Environment by NCRH. Global Journal of Researches in Engineering Chemical Engineering. 12, 3, 2012.

119. KUMAR U., ACHARYA J. Fixed Bed Column Study for the Removal of Lead from Aquatic Environment by NCRH, Research Journal of Recent Sciences, 2 (1), 9, 2013.

120. KUMAR U. Fixed Bed Column Study for the Removal of $\mathrm{Zn}$ (II) from Aquatic Waste by Sodium Carbonate Treated Rice Husk. Asian Journal of Water Environment and Pollution, 5 (2), 103, 2007.

121. GEORGE Z. KYZAS. Commercial coffee wastes as materials for adsorption of Heavy metals from aqueous solutions, Materials, 5, 1826, 2012.

122. FRANCA A.S., OLIVEIRA L.S., NUNES A.A. Malachite Green Adsorption by a Residue-based Microwaveactivated Adsorbent, Clean - Soil, Air, Water, 38 (9), 843, 2010.

123. UPENDRA K., MANAS B. Fixed Bed Column Study for Cd(II) Removal from Wastewater Treated Rice Husk. J. Hazard Mater. B129, 253, 2006.

124. LOW K.S., LEE C.K. Cadmium Uptake by the Moss, Calympress Delesserti Besch. Biosource Technol, J. 38, 1, 1991.

125. CHEKNANE B., BADU M., BASLY J.P., BOURAS O., ZERMANE F. Modeling of Basic Green 4 Dynamic Sorption onto Granular Organo-Inorgano Pillared Clays (GOICs) in Column Reactor, Chem Eng. J., 209, 7, 2012.

126. UDDIN T., RUKANUZZAMAN M., KHAN R., ISLAM A. Adsorption of Methylene Blue from Aqueous Solution 
by Jackfruit (Artocarpus heteropyllus) Leaf Powder: A Fixed-Bed Column Study. J. Environ. Mang, 90, 3443, 2009.

127. AKAR S.T., GORGULU A., AKAR T., CELIK S. Decolorization of reactive blue 49 contaminated solution by Capsicum annuum seeds: batch and continuous mode biosorption applications. Chem Eng J, 168, 125, 2011.

128. ZAYNAB ALY, VITTORIO LUCA. Uranium extraction from aqueous solution using dried and pyrolyzed tea and coffee wastes, J Radioanal Nucl Chem. 295, 889, 2013.

129. SATISH M. MANOCHA Porous Carbons, Sadhana, 28 (Part $1 \&$ 2), 335, February/April 2003.

130. BANSAL R.C. Active carbon (New York: Dekker), 1988.

131. MOHAMED E.F. Removal of organic compounds from water by adsorption and photo-catalytic oxidation", Thesis is Submitted for the Degree of Doctoral, Institute National Polytechnique Toulouse: http://ethesis.inp-toulouse.fr/ archive/00001569/01/mohamed.pdf, 2011.

132. MONSER L., ADHOUM N. Modified Activated Carbon for the Removal of $\mathrm{Cu}(\mathrm{II}), \mathrm{Z}(\mathrm{II}), \mathrm{Cr}$, and Cyanide from Wastewater, Sep. Purif Technol, 26, 137, 2002.

133. NOMANBHAY S.M., PALANISAMY K., Removal of Heavy Metals from Industrial Wastewater Using Chitosan Coated Oil Palm Shell Charcoal, Electron J. Biotecnol., 8 (1), 2005, http://www.ejbiotnology.info/content/vol8/ issue.full.7.bip/index.html

134. AMIT BHATNAGAR, MINOCHA A.K. Conventional and non-Conventional Adsorbents for Removal of Pollutants from Water - A Review, Indian Journal of Chemical Technology, 13, 203, 2006.

135. IVO O., DENNIS B., HANS-GÜNTER R. Hydrothermal carbonization of agricultural residues, Bioresource Technology, 142, 138, 2013.

136. TITIRICI M.-M., THOMAS A., ANTONIETTI M. Back in the black: hydrothermal carbonization of plant material as an efficient chemical process to treat the $\mathrm{CO}_{2}$ problem? New J. Chem. 31, 787, 2007.

137. SABOUNI R., KAZEMIAN H., ROHANI S. A novel combined manufacturing technique for rapid production of IRMOF-1 using ultrasound and microweave energies, Chem. Eng. J. 165, 966, 2010.

138. NJOKU V.O., FOO K.Y., HAMEED B.H. Microeaveassisted preparation of pumpkin seed hull activated carbon and its application for the adsorptive removal of 2,4-dichlorophenoxyacetic acid. Chemical Engineering Journal, (215-216), 383, 2013.

139. MERZOUGUI Z., ADDOUN F. Effect of Oxidant Treatment of Date Pit Activated Carbons Application to the Treatment of Waters, Desalination, 222, 394, 2008.

140. BOONPOKE A., CHIARAKORN S., LAOSIRIPOJANA N., TOWPRAYOON S., AND CHIDTHAISONG A. Synthesis of Activated carbon and MCM-41 from Bagasse and Rice Husk and their carbon dioxide Adsorption Capacity, Journal of Sustainable Energy \& Environment, 2, 77, 2011.

141. VIBOON S., CHIRAVOOT P., DUANGDAO A., DUANGDUEN A. Preparation and characterization of activated carbon from the pyrolysis of physic Nut(Jatropha curcas L.) waste. Presented at the international conference on Bioenergy Outlook, 2007.

142. GURTEN I.I., OZMAK M., YAGMUR E., AKTAS Z. Preparation and characterization of activated carbon from waste tea using $\mathrm{K}_{2} \mathrm{CO}_{3}$, Biomass and Bioenergy, 37, 73, 2012.
143. RASHIDI N.A., YUSUP S., LOONG L.H. Kinetic Studies on Carbon Dioxide Capture using Activated Carbon, Chemical Engineering Transactions, 35, 2013.

144. BENADJEMIA M., MILLIERE L., REINERT L., BENDERDOUCHE N., DUCLAUX L. Preparation, characterization and Methylene Blue adsorption of phosphoric acid activated carbons from globe artichoke leaves. Fuel Processing Technology, 92, 1203, 2011.

145. TIMUR S., KANTARLI I.C., ONENC S., YANIK J. Characterization and application of activated carbon produced from oak cups pulp, J. Anal Appl. Pyrol, 89, 129, 2010.

146. TSAI W.T., CHANG C.Y., WANG S.Y., CHANG C. F., CHIEN S.F., SUN H.F. Cleaner production of carbon adsorbents by utilizing agricultural waste corn cob. Res Conserv Rec, 32, 43, 2001.

147. GONZALEZ J.F., ROMANS., ENCINARJM., MARTINEZG. Pyrolysis of various biomass residues and char utilization for the production of activated carbons. J. Anal Appl. Pyrol; 85, 134, 2009.

148. FOO K.Y., LEE L.K., HAMEED B.H. Preparation of activated carbon by microwave assisted activation for the remediation of semi-aerobic landfill leachate, Bioresource Technology, 134, 166, 2013.

149. FOO K.Y., LEE L.K., HAMEED B.H. Preparation of banana frond activated carbon by microwave induced activation for the removal of boron and total iron from landfill leachate, Chemical Engineering Journal, 223, 604, 2013.

150. ALEXANDRO M.M. VARGAS, ANDRE L. CAZETTA, MARCOS H. KUNUTA, TAIS L. SILVA, VITRO C. ALMEUDA. Adsorption of Methylene Blue on Activated Carbon Produced from Flamboyant Pods (Delonix regia): A Study of adsorption Isotherm and Kinetic Models, Chem Eng. J., 168, 722, 2011.

151. GAO J., QIN Y., ZHOU T., CAO D., XU P., HOCHSTETTER D., WANG Y. Adsorption of methylene blue onto activated carbon produced from tea( Camellia sinensis L.) seed shells: kinetics, equilibrium, and thermodynamic studies. J. Zhejiang Univ-Sci B (Biomed \& Biotechnol), 14 (7), 650, 2013.

152. RUFFORD T.E., HULICOVA-JURCAKOVA D., ZHU Z., LU G.Q. empirical analysis of the contribution of mesopores and micropores to the double-layer capacitance of carbon, J. Phys. Chem. C113, 19343, 2009.

153. GIRGIS B.S., SMITH E., LOUIS M.M., EL-HENDAWY A.N.A. Pilot production of activated carbon from cotton stalks using $\mathrm{H}_{3} \mathrm{PO}_{4}$, I. Anal. Appl. Pyrol. 86, 180, 2009.

154. CHANDRA P.D., SAHU J.N., MOHANY C.R., MOHAN B. RAJ, MEIKAP B.C. Column Performance of Granular Activated Carbon Packed Bed for Pb (II) Removal. J. Hazard. Mat., 156, 596, 2008.

155. DEMIRBAS E., DIZGE N., SULAK M.T. AND KOBYA M. Adsorption Kinetics and Equilibrium of Copper from Aqueous Solutions Using Hazelnut Shell Activated Carbon, Chem. Eng. J., 148, 480, 2009.

156. YADAV N., MAHESWARAN S., SHUTTHANANDAN V., THEVUTHASAN S., NGO H.H., VIGNESWARAN S. Sample Preparation Techniques in Trace Element Analysis of adsorbents, 10th International Conference on Practical Induced X-Ray Emission and its Analytical Applications. PIXE Protozoa, Slovania, June 4-8, 2004.

157. http://www.sushrutchemicals.com/activatedCarbon.html

158. LOTFY H.R., MISIHAIRABGWI J., MUTWA M.M. The preparation of activated carbon from agroforestry waste for wastewater treatment, African Journal of Pure and Applied 
Chemistry 6 (11), 149, DOI: 10.5897/ AJPAC12.019, 2012.

159. REYAD A.S., DAVID A.R., RON K.B. Copper and strontium adsorption by a novel carbon material manufactured from pecan shells, Carbon 40, 781, 2002.

160. CHEREMISINOFF P.N., ELLERBUSCH F. Carbon Adsorption Handbook, Ann Arbor Science, Ann Arbor, Michigan. (Eds.), 1980.

161. YANG R.T. ADSORBENTS:FUNDAMENTALS AND APPLICATIONS, John Wiley \& Sons Inc, USA, 2003.

162. HASSLER JOHN W. Purification with Activated Carbon: Industrial, Commercial and Environmental, Chemical Publishing Company Inc., New York, N.Y, 1974.

163. GONZALES M.T., RODRIGUEZ-REINOSO F., GARCIA A.N., MARCILLAA. $\mathrm{CO}_{2}$ Activation of Carbonized under Different Experimental Conditions, Carbon, 35, 159, 1997.

164. SMISEK M., CERNY S. Active Carbon Manufacture, Properties and Application, Elsevier, Amesterdam, Netherland. 1970.

165. KUNQUAN L., XIAOHUA W. Adsorption Removal of $\mathrm{Pb}$ (II) by Activated Carbon Preparaed from Spartina alternifora: Equilibrium, Kinetics and Thermodynamics, Bioresource Technol. J., 100, 2810, 2009.

166. HOURIEH M.A., ALAYA M.N., YOUSSEF A.M. Carbon dioxide adsorption and decolorizing power of ACs prepared from pistachio shells, Adsorpt. Sci. Technol. 15, 419, 1997.

167. PATIL B.S., KULKARNI K.S. Development of high surface area activated carbon from waste material, International Journal of Advanced Engineering Research and Studies, IJAERS/Vol. I/ Issue II/January-March, 109113, 2012.

168. FOO P.Y.L., LEE L.Y. Preparation of Activated Carbon from Parkia Speciosa Pod by Chemical Activation, In: Proceedings of the World Congress on Engineering \& Computer Science, II, WCECS 2010, October 20-22, San Francisco, 2010.

169. MATSON J.S., MARK H.B. Activated Carbon: Surface Chemistry and Adsorption from Solution; Marcel Dekker Inc., New York. 1971.

170. BANSAL R.C., DONNET J.B., STOECKLI F. Active carbon. Marcel Dekker, New York, 1988.

171. EUROCARB. available at http://www.eurocarb.com, accessed in Feb 2013, 2011.

172. SUZAN SHARIFAN Activated Carbon Production from Hazelnut Shells by Thermal and Microwave Heating Methods, A thesis submitted in fulfilment of the requirements for the degree of Doctor of Philosophy, Department of Civil and Environmental Engineering, Imperial College London, 2013.

173. CHINGOMBE P., SAHA B., WAKEMAN R.J. Surface modification and characterization of a coal-based activated carbon, Carbon 43, 3132, 2005.

174. AZNAR J.S. Characterization of activated carbon produced from coffee residues by chemical and physical activation, Master Thesis in Chemical Engineering, Stockholm, Sweden, March. 2011.

175. GEORGE Z. KAND MARGARITIS K., Green Adsorbents for Wastewaters: A Critical Review, Materials, 7, 333, doi:10.3390/ma7010333., 2014

176. BRANDT R., HUGHES M., BOURGET L., TRUSZKOWSKA K., GREENLER R. The interpretation of Co Adsorbed on Pt/Sio2 of Two Different Particle-Size Distributions. Surface Science, 286 (1-2), 15, 1993.

177. TCHOBANOLOUS G., BURTON F.L., STENSL H.D. Wastewater Engineering Treatment and Reuse, Tata McGraw-Hill publishing Company Limited, New Delhi. 2003.
178. CHUN Y. YIN, MOHD K. AROUA, WAN M.A.W. DAUD. Review of Modification of Activated Carbon for Enhancing Contaminant Uptakes from Aqueous Solutions, Seperation and Purification Technology, 52, 403, 2007.

179. KIKUCHI Y., QIAN Q.R., MACHIDA M., TATSUMOTO $\mathrm{H}$. Effect of $\mathrm{ZnO}$ loading to activated carbon on $\mathrm{Pb}(\mathrm{II})$ adsorption from aqueous solution, Carbon; 44, 195, 2006.

180. BARTON S.S., EVANS M.J.B., HALLIOP E., Macdonald J.A.F. Acidic and basic sites on the surface of porous carbon, Carbon 35 (9), 1361, 1997.

181. SINGH S., MA L., HARRIS W. Heavy Metal Interaction with Phosphoric Clay: Sorption and Desrtion Behavior, J. Environ. Qual. 30, 1961, 2001.

182. CHANTAWONG V., HARVEY N.W., BASHKIN V.N. Comparison of Heavy Metal Adsorption by Thai Kaoline Ballclay. Water Air Soil Pollut. J., 148, 111, 2003.

183. WILLIAM D.B. Heavy Metal Adsorbents for Storm Water Pollution Prevention, Ph D. Thesis, Department of Civil and Environmental Engineering, the Pennsylvania State Univ. Under the National Shipbulding Research Program., 1997.

184. OMRI A., BENZINA M. Removal of manganese(II) ions from aqueous solutions by adsorption on activated carbon derived a new precursor: Ziziphus spina-christi seeds, Alexandria Engineering Journal, 51, 343, 2012.

185. SHAREEF K.M. Sorbents for contaminates uptake from aqueous solutions. Part I: Heavy metals. World journal of Agricultural Sciences, 5 (S), 819, 2009.

186. EL QADA E.N., ALLEN S.J., WALKER G.M. Adsorption of methylene blue onto activated carbon produced from steam activated bituminous coal: a study of equilibrium adsorption isotherm, Chem. Eng. J. 124, 103, 2006.

187. HAIRUL N.A., KELLY L.K.M. Adsorption of Basic Red 46 by Granular Activated Carbon in a Fixed Bed Column, International Conference on Environment and Industrial Innovation, IPCBEE, 21, Singapore, 2011.

188. HASAN S.H., RANJANA D., TALAT M. Agro-industrial Waste Wheat Bran for the Bio-sorptive Remediation of Selenium Through Continuous up-flow Fixed Bed Column. J. Hazard Mater, 181, 1134, 2010.

189. ALVAREZ S., SOTELO J.L., OVEJERO G., RODRIGUES A., GARCIA J. Low Cost Adsorbent for Emerging Contaminant Removal in Fixed-Bed Columns, Chemical Engineering Transactions, 32, 61, 2013.

190. MUHAMMAD A., MISBAHUL A.K., UMAR F., MAKSHOOF A. Chabonized Green Tea Dredge, a Potential Adsorbent for Removal of Remazol Brilliant Yelow Dye, J. Mater. Environ. Sci. 3 (1), 149, 2013.

191. VOLESKY B. Sorption and Biosorption BV Sorbex, Inc., Montreal., 2004.

192. LEE S.M., DAVIS A. P. Removal of $\mathrm{Cu}(\mathrm{II})$ and $\mathrm{Cd}(\mathrm{II})$ from Aqueous solution by Seafood Processing Waste Sludge. Water Res., 35 (2), 534. 2001.

193. SECO A., GABALDON C., AND MARZAL P. Effect of $\mathrm{pH}$, Cation Concentration and Adsorbent Concentration on Cadmium and Copper Removal by Granular Activated Carbon, J. Chem. Technol. Biotechnol., 74, 911, 1999.

194. KUMAR P., DARA S.S. Modified Barks for Scavenging Toxic Metal Ions, Indian J. Environ. Health, 22, 196, 1980

195. GIAKWAD R.W. Removal of Cd(II) from Aqueous Solution By Activated Carbon Derived From Cocount Shell, Agric. Food Chem., 1579, 2004.

196. SCIBAN M., KALASNJA M., AND SKRBIC B. Modified Softwwod Sawdust as Adsorbent of Heavy Metal Ions from Water, J. Hazard. Matter, 136, 2, 266, 2006. 
197. KADIRVELU K., NAMASIVAYAN C. Activated Carbon from Coconut Coirpith as Metal Adsorbent: Adsorption of $\mathrm{Cd}$ (II) from Aqueous Solution, Advanced in Environmental Research, 7, 471, 2003.

198. RAMMEL R.S., ZATITI S.A., EL JAMAL M.M. Biosorption of crystal violet by chaetophora elegans alga. Journal of the University of Chemical Technology and Metallurgy, 46, 3, 283, 2011.

199. BHARATHI K.S., RAMESH S.P. Equilibrium, Thermodynamics and Kinetics Studies on Adsorption of a Basic Dye by Citrulus Lanatus Rind. Iranica J. Energ. Environ., 3 (1), 23, 2012.

200. CENGIZ S., CAVAS L. A Promising Evaluation Method for Dead Leaves of Poidonia Oceanic (L.) in the Adsorption of Methyl Violet, Mar. Biotechnol. DOI 10.11007/s/10126010-9260-8., 2010.

201. AWALA H., JAMAL M.M. Equilibrium and Kinetics Study of Adsorption of Some Dyes onto Feldspar, J. Univ. Chem. Technol. Met., (Sofia) 44, 157, 2010.

202. MALIK P.K. Use of activated carbons prepared from sawdust and rice husk for adsorption of acid dyes: a case study of Acid Yellow 36, Dyes and Pigments, 56, 239, 2003.

203. SIVAKUMAR P., PALANISAMY P.N. Packed bed column syudies for the removal of Acid blue92 and Basic red 29 using non-conventional adsorbent, Indian Journal of Chemical Technology, 16, 301, 2009.

204. KO D.C.K., PORTER J.F., MCKAY G. Optimized Correlations for the Fixed-Bed Adsorption of Metal Ions on Bone Char. Chem. Eng. Sci., 55, 5819, 2000.

205. TATY-COSTODES, V., FAUDUET, H., PORTE, C., AND HO, S. Removal of Lead (II) Ions from Synthetic and Real Effluents Using Immobilized Pinus Svlvestris Sawdust: Adsorption on a Fixed Column. J. Hazard Mater., 123, 135, 2005.

206. GOEL J., KADIRVELU K., RAJAGOPAL C., GARG V.K. Removal of Lead (II) by adsorption using treated granular activated carbon: batch and column studies, J Hazard Mater, 125, 211, 2005.

207. SULAYMAN A.H., THAMER J.M., AL-NAJAR J. Equilibrium and Kinetics Studies of Adsorption of Heavy Metals onto Activated Carbon. Canadian J. Chem. Engin. Technol, 3 (4), 86, 2012.

208. GUPTA S., BABU B.V. Modeling, simulation, and experimental validation for continuous $\mathrm{Cr}(\mathrm{VI})$ removal from aqueous solutions using sawdust as an adsorbent. Biores. Technol. 100 (23), 5633, 2009.

209. HAMDAOUI O. Removal of Rodamine B from Aqueous Solutions by Tea Wastes. J Hazard. Mater., 135, 264, 2006

210. FOO K.Y., HAMEED B.H. Dynamic adsorption behavior of methylene blue onto oil palm shell granular activated carbon prepared by microwave heating. Chem Eng J, 203, 81, 2012.

211. SNOEYINK V.L., SUMMERS R.S. Adsorption of Organic Compounds: Water Quality and Treatment. Chapter 13, McGraw- Hill, New York, 1999.

212. (ACE): Army Corps of Engineers: «Engineering Design: Adsorption Design Guide». [Internet], Department of the Army, USA, DG1110- 1-2, 2001. Available at: http://www. wbdg.org/ccb/ARMYCOE/COEDG/dg_1110_1_2.pdf

213. VIJAYARAGHAVAN K., JEGAN L., PALANIVELU K., VELAN M. Removal of Nickle (II) ions from Aqueous Solution Using Crab Shell Particles in a Packed Bed upFlow Column. J. Hazard. Mater, 113, 223, 2004.

214. EL-WAKIL A.M., ABOU EL-MAATY W.M., AWAD FS. Removal of Lead from Aqueous Solution on Activated
Carbon and Modified Activated Carbon Prepared from Dried Water Hyacinth Plant. J Anal Bioanal Tech, 5 (2) 2014, http://dx.doi.org/10.4172/2155-9872.1000187,

215. DWIVEDI C.P., SAHU J.N., MOHANTY C.R., RAJPHAN B., MEIKAP B.C. Column performance of granular activated carbon packed bed for $\mathrm{Pb}$ (II) removal, J. Hazardous Materials, 156, 596, 2008.

216. NADEEM M., SHABBIR M., ABDULLAH A., SHAH S., MCKAY G. Sorption of Cadmium from Aqueous Solution by Surfactant-Modified Carbon Adsorbents. Chem. Engi. J. 148, 365, 2009.

217. SAAD S.A., ISA K.M.D., BAHARI R. Chemically modified sugarcane bagasse as a potentially low-cost biosorbent for dye removal. Desalination, 264, 123, 2010.

218. SHAOBIN W., BOYJOO Y., CHOUEIB A., ZHU Z.H. Removal of dyes from aqueous solution using fly ash and red mud, Water Resource, 39, 129, 2005.

219. THAJEEL A.S., RAHEEM A.Z., AL-FAIZE M.M. Production of activated carbon from local raw materials using physical and chemical preparation methods, Journal of Chemical and Pharmaceutical Research, 5 (4), 251, 2013.

220. HESAS R.H., ARAMI-NIYA A., WAN MOHD A.W. D., SAHU J.N. Preparation and characterization of activated carbon from apple waste by Microwave-assisted phosphoric acid activation : application in methylene blue adsorption, Bio Resources. 8 (2), 2959, 2013.

221. US EPA, United States Environmental Protection Agency, Choosing an Adsorption System for VOC: Carbon, Zeolite, or Polymers. Clean Air Technology Center, Office of Air Quality Planning and Standards, Technical Bulletin, Clean Air Technology Center-USEPA. May. 1999.

222. RUTHVEN D.M. Principles of Adsorption and Adsorption Process, Wiley, New York., 1984.

223. THOMAS A.H., NIVETA J., JOSHI H.C., PRASAD S. Agricultural and Agro-Processing Wastes as Low Cost Adsorbents for Metal Removal from Wastewater: A Review, J. Scie. Ind. Rese., 67, 647, 2008.

224. BANSODE R.R., LOSSO J.N., MARSHALL W.E., RAO R.M. Adsorption of Metal Ions by Becan Shell-Based Granular Activated Carbons, L. Biores. Technol, 89, 115, 2003.

225. ANIRUDHAN T., RADHAKIRSHNAN P. Thermodynamics and Kinetics of Adsorption of $\mathrm{Cu}(\mathrm{II})$ from Aqueous Solutions onto a New Cation Exchanger Derived from Tamirand Fruit Shell, J. Chem. Thermo., 40, 702, 2008.

226. SRIVASTAVA S.K., SINGH A.K., SHARMA A. Studies on the Uptake of Lead and Zinc by Lignin Obtained from black Liquor- A paper Industry Waste Material, Environ. Technol, 15 (4), 353, 1994.

227. MADHAVA M.R.., REDDY D.H.K.K., VENKATESWARLU P., SESHIAH K. Removal of Mercury from Aqueous Solution Using Activated Carbon from Agricultural by Product/Waste. J. Environ. Manag. 90, 634, 2009.

228. KADIRVELU K.., THAMARAISELVI K., NAMASIVAYAM C. Removal of Heavy Metals from Industrial Wastewater by Adsorption onto Activated Carbon Prepared from Agricultural Solid Waste. Bioresource Technology Journal, 76, 63, 2001.

229. GHARAIBEH S.H., ABU-EL-SHAR W.Y., AL-KOFAHI M.M. Removal of Selected Heavy Metals from Aqueous Solutions Using Processed Solid Residue of Olive Mill Products, Wat. Res. J., 32 (2), 498, 1998.

230. AUTA M., HAMEED B.H. Preparation of waste tea activated carbon using potassium acetate as an activating 
agent for adsorption of Acid Blue 25 dye, Chemical Engineering Journal, 171, 502, 2011.

231. GURTEN I.I., OZMAK M., YAGMUR E., AKTAS Z. Preparation and characterization of activated carbon from waste tea using $\mathrm{K}_{2} \mathrm{CO}_{3}$. Biomass and Bioenergy, 37, 73, 2012.

232. AUTA M. Optimization of tea waste activated carbon preparation parameters for removal of Cibacron Yellow dye from textile waste waters, International Journal of Advanced Engineering Research and Studies. I, 50, 2012.

233. AKAR E.., ALTINISIK A., SEKI Y. Using of activated carbon produced from spent tea leaves for the removal of malachite green from aqueous solution. Ecological Engineering, 52, 19, 2013.

234. ÖZSINN G.., PÜTÜN E., KILIÇ M., PÜTÜN A. Production of Microwave Induced Activated Carbon and Its Application to Remove Phenol from Aqueous Solutions. Digital Proceeding of The ICOEST', Cappadocia C.Ozdemir, S. Şahinkaya, E. Kalıpcı, M.K. Oden (editors) Nevsehir, Turkey, June 18-21, 2013.

235. JAHIN H. S. Adsorption of Methyl Red from Aqueous Solutions Using Activated Carbon Prepared from Coffee Residue, International Journal of Environment 3 (2), 126, 2014.

236. SEKIRIFA M.L., CHERRAYE R., HADJ-MAHAMMED M., CHENINE M., BAAMEUR L., AL-DUJAILI H.A. Chemical activation of an Activated carbon Prepared from coffee residue, Energy Procedia, 50, 393,. 2014.

237. ABDEL RAHIM M.A., ISMAIL M.M., ABDEL MAGEED A.M. Production of activated carbon and precipitated white nanosilica from rice husk ash", International Journal of Advanced Research, 3 (2), 491, 2015.

238. HARIPRASAD P., RAJESHWARI S., Cu A. Preparation and characterization of activated carbon from rice husk", International Research Journal of Engineering and Technology, 3, 4., 2016.

239. GÜRSES A., DOĞAR C., KARACA S., AÇIKYILDIZ M., BAYRAK R. Production of granular activated carbon from waste Rosa canina sp. seeds and its adsorption characteristics for dye, J. Hazard. Mater, B131, 254, 2006.

240. CALVETE T., EDER C.L., NATALI F.C., SILVIO L.P. D., FLAVIO A.P. Application of carbon adsorbents prepared from the Brazilian pine-fruit-shell for the removal of Procion Red MX 3B from aqueous solution-kinetic, equilibrium, and thermodynamic studies, Chem. Eng. J. 155, 627, 2009.

241. AKPEN G.D., NWAOGAZIE I.L., LETON T.G. Optimum conditions for the removal of colour from waste water by mango seed shell based activated carbon, Indian Journal of Science and Technology. 4 (8), 890, 2011.

242. SAID N., AMALINA R., MAZZA S.A.A., SYAFIQAH A.K., HAJAR A.M.S. Rock Melon Activated Carbon (RMAC) for Removal of $\mathrm{Cd}(\mathrm{II}), \mathrm{Ni}(\mathrm{II})$ and $\mathrm{Cu}(\mathrm{II})$ from Wastewater: Kinetics and Adsorption Equilibrium, International Journal of Chemical Engineering and Applications, 6 (2), 105, 2015.

243. MUTHANNA J.A., SAMAR K.T., ABDUL-HALIM A.K.M. Adsorption of Phenol And P-Nitro Phenol onto Date Stones: Equilibrium Isotherms, Kineticsand Thermodynamics Studies, Journal of Engineering, 18 (6), 743, 2012.

244. ACKACHA M.A., ELMAHDY S.A. Utilization of new activated carbon derived from date stones to reduce of Lead and Cadmium ions from aqueous solutions. 2nd International conference on environmental Science and Technology. IPCBEE., 2011.

245. NAJAR-SOUISSI S., OUEDERNI A., RATEL A. Adsorption of Dyes onto Activated Carbon Prepared from Olive Stones. Journal of Environmental Science, 17 (6), 998, 2005.

246. WAHBY A., ABDELOUAHAB-REDDAM Z., EL MAIL R., STITOU M., SILVESTRE-ALBERO J., SEPÚLVEDAESCRIBANO A., RODRÍGUEZ-REINOSO F. Mercury removal from aqueous solution by adsorption on activated carbons prepared from olive stones. Adsorption, 17, 603, 2011.

247. PATNUKAO P., KONGSUWAN A., PAVASANT P. Batch studies of adsorption of copper and lead on activated carbon from Eucalyptus camaldulensis Dehn. Bark. Journal of Environmental Sciences 20, 1028, 2008.

248. OMRI ABDESSALEM, BENZINA MOURAD Removal of manganese(II) ions from aqueous solutions by adsorption on activated carbon derived a new precursor: Ziziphus spina-christi seeds. Alexandria Engineering Journal, 51, 343, 2012.

249. SAYAN E. Ultrasound-assisted preparation of activated carbon from alkaline impregnated hazelnut shell: An optimization study on removal of $\mathrm{Cu}^{2+}$ from aqueous solution. Chem. Eng. J. 115, 213, 2006.

250. MADHAVA M. RAO, RAMESH A., RAO G.P.C., SESHAIAH K. Removal of copper and cadmium from the aqueous solutions by activated carbon derived from Ceiba pentandra hulls, Journal of Hazardous Materials B129, 123, 2006. 